\title{
24. REGIONAL GEOCHEMISTRY OF THE LAU-TONGA ARC AND BACKARC SYSTEMS ${ }^{1}$
}

\author{
A. Ewart, ${ }^{2}$ W.B. Bryan, ${ }^{3}$ B.W. Chappell, ${ }^{4}$ and R.L. Rudnick ${ }^{5}$
}

\begin{abstract}
Detailed comparison of mineralogy, and major and trace geochemistry are presented for the modern Lau Basin spreading centers, the Sites 834-839 lavas, the modern Tonga-Kermadec arc volcanics, the northern Tongan boninites, and the Lau Ridge volcanics. The data clearly confirm the variations from near normal mid-ocean-ridge basalt (N-MORB) chemistries (e.g., Site 834, Central Lau Spreading Center) to strongly arc-like (e.g., Site 839, Valu Fa), the latter closely comparable to the modern arc volcanoes. Sites 835 and 836 and the East Lau Spreading Center represent transitional chemistries. Bulk compositions range from andesitic to basaltic, but lavas from Sites 834 and 836 and the Central Lau Spreading Center extend toward more silica-undersaturated compositions. The Valu Fa and modern Tonga-Kermadec arc lavas, in contrast, are dominated by basaltic andesites. The phenocryst and groundmass mineralogies show the strong arc-like affinities of the Site 839 lavas, which are also characterized by the existence of very magnesian olivines (up to $\mathrm{Fo}_{90-92}$ ) and $\mathrm{Cr}$-rich spinels in Units 3 and 6 , and highly anorthitic plagioclases in Units 2 and 9.

The regional patterns of mineralogical and geochemical variations are interpreted in terms of two competing processes affecting the inferred magma sources: (1) mantle depletion processes, caused by previous melt extractions linked to backarc magmatism, and (2) enrichment in large-ion-lithophile elements, caused by a subduction contribution. A general trend of increasing depletion is inferred both eastward across the Lau Basin toward the modern arc, and northward along the Tongan (and Kermadec) Arc. Numerical modeling suggests that multistage magma extraction can explain the low abundances (relative to N-MORB) of elements such as $\mathrm{Nb}, \mathrm{Ta}$, and $\mathrm{Ti}$, known to be characteristic of island arc magmas. It is further suggested that a subduction jump following prolonged slab rollback could account for the initiation of the Lau Basin opening, plausibly allowing a later influx of new mantle, as required by the recognition of a two-stage opening of the Lau Basin.
\end{abstract}

\section{INTRODUCTION}

During the past decade, the Lau Basin and Tonga Ridge have been explored by a relatively large number of cruises, culminating in the Ocean Drilling Project (ODP) Leg 135. Notable among these cruises are those of the Thomas Washington (e.g., Volpe et al., 1988); S.P. Lee (Scholl et al., 1985; Vallier et al., 1991); Sonne in 1984/85 and again in 1987 (e.g., von Stackelberg and Shipboard Scientific Party, 1985, 1988; Sunkel, 1990; Frenzel et al., 1990); Charles Darwin (e.g., Parson et al., 1990; Collier and Sinha, 1990); Natsushima (Falloon and Crawford, 1991; Falloon et al., 1987); and Akademik Mstislav Keldysh (Falloon et al., 1992). The results accumulated by these cruises now allow the compilation of a good data base of petrological, geochemical, morphological, and geophysical data on which to develop models based on the recognition of patterns of geochemical behavior, interrelated temporally and geographically to the progressive opening of the Lau Basin. To these ends, the Leg 135 drill sites have provided the invaluable additional dimension of timing.

Particular scientific interest in the active Lau Basin arises from the recognition of a range of compositions extending from near-normal mid-ocean-ridge basalt (N-MORB) in the central spreading ridges to basalts enriched in large-ion-lithophile elements (LILEs) and lightrare-earth elements (LREEs), the so-called transitional or T-type basalts (Hawkins and Melchior, 1985). More recent studies have shown that the lavas within the southern Lau Basin, notably the Valu Fa Ridge, have distinctly "arc-like" geochemical characteristics (e.g., Sunkel, 1990; Boespflug et al., 1990; Vallier et al., 1991). Apart from

\footnotetext{
${ }^{1}$ Hawkins, J., Parson, L., Allan, J., et al., 1994. Proc. ODP, Sci. Results, 135: College Station, TX (Ocean Drilling Program).

${ }^{2}$ Department of Earth Sciences, University of Queensland, St. Lucia, Queensland 4072, Australia.

${ }^{3}$ Woods Hole Oceanographic Institution, Department of Geology and Geophysics. Woods Hole, MA 02543, U.S.A

${ }_{5}^{4}$ Department of Geology, Australian National University

${ }^{5}$ Research School of Earth Sciences, Australian National University, G.P.O. Box 4. Canberra, ACT 2601, Australia.
}

considerations as to the origins of these variations, it is also necessary to obtain a clearer geographic and temporal picture of these patterns of regional variations, and to compare them with the adjacent modern arc volcanoes of Tonga. Another relevant question is that of the status, if any, of a distinct backarc basin basalt type.

The purpose of this paper, therefore, is to bring together existing geochemical data on the spreading centers of the Lau Basin, to compare these data with the modern axial Tongan and Kermadec volcanoes (i.e., the modern arc volcanic systems) and the older arc volcanics of the Lau Ridge, and to relate these data further to the volcanic sequences recovered in Sites 834-839 of Leg 135. In addition, the boninites from the northern end of the Tonga Ridge are also included in these comparisons, as these lavas clearly constitute an integral part of the arc and backarc systems.

It is relevant to provide here a brief summary of the major volcanic types encountered at Sites 834-839 (Parson, Hawkins, Allan, et al., 1992). Samples from Site 834 were expected to represent some of the oldest Lau Basin crust, and paleontological dating of sediments overlying the inferred volcanic basement implies that basin opening and volcanism had begun by $5.6 \mathrm{Ma}$. The volcanics recovered include plagioclase-olivine-clinopyroxene basalts, exhibiting varying degrees of fractionation with $\mathrm{mg}$ ratios $\left(=\mathrm{mol} \% \mathrm{Mg} / \mathrm{Mg}+\mathrm{Fe}_{\mathrm{t}}\right)$ ranging from 33 to 67 , including relatively $\mathrm{Mg}$-rich tholeiites $(\mathrm{mg}=61-67)$, and high Fe-Ti basaltic andesites $(\mathrm{mg}=33-43)$. Site 835 lavas are overlain by late Pliocene sediments (ca. $3.5 \mathrm{Ma}$ ), and comprise relatively unfractionated tholeiites $(\mathrm{mg}=55-63)$. Site 836 volcanic basement (minimum age $0.7 \mathrm{Ma}$ ) consists of olivine tholeiites $(\mathrm{mg}=61-68)$, basaltic andesite $(\mathrm{mg}=45-47)$ and andesite $(\mathrm{mg}=36-39)$. Sites 837 and 838 (ca. 2.0 Ma minimum ages) yielded only limited volcanic horizons. These comprised some $4 \mathrm{~m}$ of two-pyroxene andesite $(\mathrm{mg}=$ 34-35) (Site 837), and gravels of basaltic andesite $(\mathrm{mg}=40-50)$ and andesite $(\mathrm{mg}=28)($ Site 838$)$. Site 839 , with a probable age of 1.25 to $>2.2 \mathrm{Ma}$, comprises a sequence of remarkable olivine-phyric, high$\mathrm{MgO}$ tholeiites to picritic basalts $(\mathrm{mg}=57-75)$, together with magnesian tholeiites ( $\mathrm{mg}=64-67)$ and two-pyroxene basaltic andesites (mg $=39-50$ ). Detailed stratigraphy of the units recovered at each site are given in Parson, Hawkins, Allan, et al. (1992). 
The modern volcanoes of the Tongan Islands are dominated by two- pyroxene + plagioclase basaltic andesites with minor andesites and dacites, the most notable of the latter being on the island of Fonualei (Ewart et al., 1973). Even more remarkable is the 1969 Metis Shoal eruption (Melson et al., 1970) of low $\mathrm{K}_{2} \mathrm{O}$ rhyolitic glass with xenocrysts of olivine $\left(\mathrm{Fo}_{93}\right)$, bronzite, diopsidic augite, and bytownite. The Kermadec Islands are more diverse, with significant eruptions of olivine basalts, together with two-pyroxene and plagioclase basaltic andesites, andesites, dacites, and rare low-K rhyolites (Ewart et al., 1977).

\section{METHODS AND TECHNIQUES}

The approach taken has been to use existing published literature to characterize the gross geochemical features of the currently recognized major spreading ridge systems, namely, the Central Lau Spreading Center (CLSC), the Intermediate and Eastern Lau spreading centers (ILSC and ELSC), the Valu Fa Ridge (VF), and the King's Triple Junction (KTJ) in the northeastern part of the basin (Fig. 1). The first four of these divisions follow from the imagery results of Parson et al. (1990), together with the inferred history of development of these ridges as southward-moving propagators (Parson and Hawkins, this volume), an interpretation with considerable geochemical implications. The KTJ (Falloon et al., 1992) is inferred to represent three intersecting spreading centers and a transform fault (Parson et al., 1990), situated in the northeastern Lau Basin. As far as possible, only data from these ridge systems are included, with seamounts being specifically excluded from this compilation. The omission of seamount data is justified on the basis that these may represent superimposed, localized thermal plume features, and thus are not necessarily directly representative of the actual propagating ridge systems. Nevertheless, some comparative data from the subaerially exposed active volcano of Niuafo'ou (Fig. 1) are included for comparison.

In terms of interrelating the history of volcanism of the Lau Basin, as seen in the Leg 135 cores, with the later development of the ridge propagator systems, it is geochemically critical to note the positions of Sites 834 to 839 with respect to the two morphotectonic domains recognized by Parson and Hawkins (this volume). These comprise the western half of the basin in which a horst-and-graben topography is developed, and the younger ( $<2 \mathrm{Ma})$ eastern half is characterized by more typical seafloor spreading fabric. The latter region is interpreted as having formed from the still active propagating spreading ridges. Sites 834,835 , and 838 lie within the western region, and Site 839 is very close to the boundary, but just inside the western region, whereas Site 836 and possibly Site 837 (Hergt and Hawkesworth, this volume) lie within the eastern zone, presumably on ELSC crust. It is relevant, therefore, to note the importance of especially Site 836 in the following interpretations.

In the mineralogical, major element, and trace element plots presented in this chapter, the following data sources are used: Bauer (1970), Baker et al. (1971), Oversby and Ewart (1972), Ewart et al. (1973, 1977), Ewart (1976), Gill (1976), Hawkins (1976), Johnstone (1978), Kay and Hubbard (1978), Hawke (1983), Cole et al. (1985, 1990), Hawkins and Melchior (1985), Vallier et al. (1985, 1991), Ewart and Hawkesworth (1987), Falloon et al. (1987, 1989, 1992), Jenner et al. (1987), Frenzel et al. (1990), Boespflug et al. (1990), Loock et al. (1990), Sunkel (1990), Falloon and Crawford (1991), and Ernewein et al. (in press). Additional unpublished Kermadec data were made available by Dr. J.A. Gamble. Extensive use of the Leg 135 shipboard X-ray fluorescence (XRF) data is made and included in all relevant element plots. These are supplemented by new modal data (Table 1) and new trace and major element analyses of 38 samples, 26 from Sites 834-839 and the remainder from the Tonga and Kermadec Islands (Tables 2-5).

Trace element analyses of oceanic island arc related lavas are especially challenging because of the very low abundance levels of the high-field-strength elements (HFSEs), the rare-earth elements
(REEs), and even the LILEs (e.g., Rb, Cs), even though the latter are relatively "enriched." As is evident from the data presented in this and related papers in this volume, the Lau-Tonga lavas exhibit more extreme depletions of most of these elements than other documented arc systems. To check the general validity of the trace element analyses, all samples were analyzed by XRF (University of Queensland), inductively coupled plasma mass spectrometry (ICP-MS) (Monash University), and instrumental neutron activation analyses (INAA) (Australian National University). In addition, six samples have been analyzed by spark source mass spectrometry (SSMS) (Australian National University). The separate data sets are shown in Tables 2-5. Although differences are apparent among the techniques for some REE, LILE, and HFSE data, on the broad comparative data plots being used (e.g., the spidergrams), the data form encouragingly coherent data sets. A discussion of the comparative data obtained by the various techniques is presented in the Appendix. For purposes of internal consistency, however, only the XRF and ICP-MS data are used in the accompanying elemental plots. Details of analytical techniques used are provided in the Appendix.

\section{MINERALOGY}

Composite plots of plagioclase, olivine, and pyroxene compositions are presented (Figs. 2-4) for the major units from Sites 834 to 837 , noting that the phenocrystal assemblage plagioclase \pm olivine \pm augite (+ orthopyroxene in basaltic andesites and andesites of Site 837) occurs throughout these sequences. Comparable mineral data for the Site 839 lavas are presented in Ewart et al. (this volume), whereas detailed documentation of the oxide phases are presented by Allan and also Nilsson (both in this volume).

Plagioclase phenocryst compositions in Site 834 lavas are dominantly bytownite, being most calcic in the most magnesian Units 5 and $7\left(\mathrm{An}_{77-89}\right)$, and least calcic in the relatively fractionated Unit 12 $\left(A n_{51-58}\right)$. Within Site 835 , compositions are bytownite, but more variable $\left(\mathrm{An}_{72-90}\right.$, predominantly between $\left.\mathrm{An}_{73-77}\right)$, probably in part reflecting the gradation from phenocryst to microphenocrysts. Plagioclase compositions within Site 836 lavas are similarly bytownite $\left(\mathrm{An}_{82-90}\right)$, being predictably most calcic in the relatively $\mathrm{MgO}$-rich Unit 3 (mg 66), and least calcic in the andesitic Unit 1. Even within this latter unit, however, core compositions of $>\mathrm{An}_{89}$ sporadically occur, suggesting the preservation of xenocrystal (or inherited) plagioclase remnants from more primitive parental melts. Within Site 839 , plagioclases are bytownite within the tholeiitic and picritic Units $1,3,4$, and 6 , but are more calcic in the basaltic andesites of Units 2 and 9 , extending into the anorthite range. In this respect, the Site 839 basaltic andesites are similar to the modern Tofua Arc basaltic andesites (see fig. 2 in Ewart et al., this volume). Such highly calcic compositions in the basaltic andesites suggest "inherited" relict plagioclase from more primitive precursor magmas; even these, however, would need to represent low sodium melts to precipitate such calcic plagioclases (e.g., Falloon et al., 1988).

Olivine phenocryst and microphenocryst compositions (Fig. 3) within Site 834 lavas extend up to $\mathrm{Fo}_{89}$ (Unit 7), to $\mathrm{Fo}_{63-71}$ for the relatively fractionated Unit 12 . The majority of olivines range between $\mathrm{FO}_{78}$ and $\mathrm{Fo}_{88}$. Compositions within the Unit 3 tholeiites of Site 836 are $\mathrm{Fo}_{86-89}$, being slightly lower in Unit $4\left(\mathrm{Fo}_{82-87}\right)$, and more so in the basaltic andesite of Unit $5\left(\mathrm{Fo}_{74-79}\right)$. Within Site 839, olivines occur in the Unit 1 tholeiite $\left(\mathrm{Fo}_{81-87}\right)$, the picritic Units 3 and 6 $\left(\mathrm{Fo}_{83-92}\right.$, mostly between $\mathrm{Fo}_{90}$ and $\left.\mathrm{FO}_{92}\right)$, and Unit $4\left(\mathrm{Fo}_{82-90}\right)$.

One major point of significance concerns the extreme level of magnesium enrichment represented by the olivines in these various backarc lavas, with those of Units 3 and 6 in Site 839 being the most magnesian olivines encountered in the Leg 135 drill sites. These compositions compare with reported compositions of $\mathrm{Fo}_{92-4}$ for the northern Tongan boninitic lavas, $\mathrm{FO}_{90.6}$ and $\mathrm{Fo}_{91.4}$ for the Valu $\mathrm{Fa}$ and ELSC, $\mathrm{Fo}_{87}$ for $\mathrm{KTJ}, \mathrm{Fo}_{86}$ for CLSC, and $\mathrm{Fo}_{83}$ for the Niuafo' ou lavas. Very forsteritic xenocrystal olivines $\left(\mathrm{Fo}_{90-93}\right)$ are also reported from 


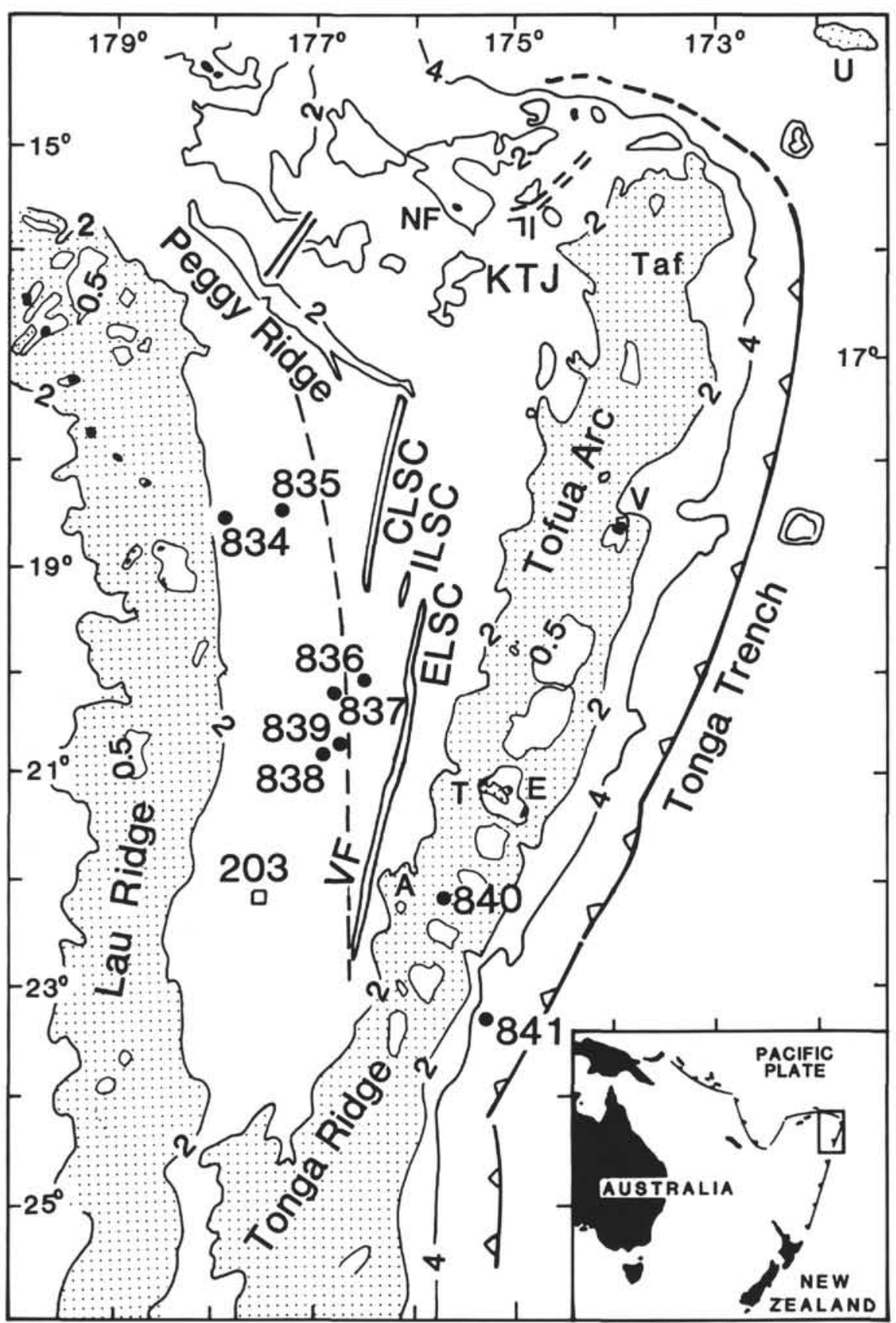

Figure 1. Location map of Lau Basin, showing bathymetry $(\mathrm{km})$, locations of Lau and Tonga ridges, and Leg 135 drill sites (including DSDP Site 203). Islands shown are Niuafo'ou (NF), Tafahi (Taf), Tongatapu (T), 'Eua (E), 'Ata (A), Upolu (U), and Vava'u (V). Also shown (dashed line) is the approximate boundary between the older western and younger eastern Lau Basin provinces (Parson and Hawkins, this volume). CLSC $=$ Central Lau Spreading Center, ELSC $=$ East Lau Spreading Center, ILSC $=$ Intermediate Lau Spreading Center, and KTJ = King's Triple Junction.

Metis Shoal and Tofua in the modern Tofua Arc. The significance of such magnesian olivines lies in the implied refractory nature of their mantle source (e.g., Duncan and Green, 1987). The most magnesian (or "refractory") compositions seem to occur in those magmas showing strongest arc-like geochemical signatures.

Pyroxenes (Fig. 4) in the Site 834 lavas range from diopsidic augite to augite, with limited $\mathrm{Fe}$-enrichment occurring in interstitial groundmass grains. Slight Fe-enrichment also occurs in phenocrystal augites in the relatively fractionated Unit 12. No trends toward subcalcic and low-Ca compositions are evident. Very similar pyroxene compositions occur in the Unit 4 tholeiites of Site 836. The tholeiites of Site 835 carry similar diopsidic augite phenocrysts, but slightly less calcic than those occurring in the Site 834 lavas. In contrast, the groundmass pyroxenes occurring in the basaltic andesites of Unit 5, Site 836, and the Site 837 andesites, exhibit trends into the subcalcic augite fields, whereas the Site 837 andesites also contain coexisting phenocrystal augite and orthopyroxene. Data for the Site 839 pyroxenes (fig. 4 in Ewart et al., this volume) illustrate the tendency for the phenocryst and microphenocryst pyroxenes from the tholeiitic and picritic Units 3 and 4, and the basaltic andesites of Units 2 and 9, to extend to less calcic compositions; the data also show the extensive development of subcalcic to pigeonitic compositions in 
Table 1. Summary of modal data (vol\%) for newly analyzed samples, Sites 834-839.

\begin{tabular}{|c|c|c|c|c|c|c|c|c|c|c|c|c|c|c|c|}
\hline Hole: & $834 \mathrm{~B}$ & $834 \mathrm{~B}$ & $834 \mathrm{~B}$ & $834 \mathrm{~B}$ & $834 B$ & $834 \mathrm{~B}$ & $834 B$ & $834 B$ & $834 \mathrm{~B}$ & $835 B$ & $835 \mathrm{~B}$ & $836 \mathrm{~A}$ & $836 \mathrm{~A}$ & $836 \mathrm{~B}$ & $836 \mathrm{~B}$ \\
\hline Core, section: & $8 R-2$ & $11 \mathrm{R}-3$ & $-3 \quad 15 R-2$ & $31 R-3$ & $35 R-1$ & $37 R-1$ & $40 \mathrm{R}-1$ & $55 R-1$ & 57R-1 & $4 \mathrm{R}-1$ & $7 R-1$ & $3 \mathrm{H}-3$ & $4 \mathrm{H}-\mathrm{CC}$ & $6 R-1$ & $9 \mathrm{M}-1$ \\
\hline Interval $(\mathrm{cm})$ : & $12-18$ & $8 \quad 86-89$ & $9 \quad 47-56$ & $73-78$ & $58-60$ & $36-42$ & $57-60$ & $23-25$ & $126-128$ & $131-141$ & $15-22$ & $30-90$ & $0-13$ & $105-110$ & $117-122$ \\
\hline Unit or subunit: & 2 & 5 & 6 & 7 & 8 & $9 \mathrm{~B}$ & $10 \mathrm{~A}$ & 12 & 13 & 1 & 1 & 1 & 3 & $4 B$ & 5 \\
\hline \multicolumn{16}{|l|}{ Phenocrysts: } \\
\hline Plagioclase & 0.2 & - & 9.3 & 11.1 & $8.0^{a}$ & 13.4 & $0.8^{2}$ & $8.5^{\mathrm{a}}$ & 9.0 & $11.6^{\mathrm{a}}$ & 11.3 & - & $13.7^{\mathrm{a}}$ & - & $17.1^{\mathrm{a}}$ \\
\hline Clinopyroxene & 1.2 & - & 4.1 & - & $\begin{array}{l}0.0 \\
5.2^{a}\end{array}$ & $\begin{array}{r}15.4 \\
1.6\end{array}$ & $0.7^{\mathrm{a}}$ & 2.6 & 2.8 & $5.7^{\mathrm{a}}$ & $0.9^{\mathrm{a}}$ & - & - & - & 0.1 \\
\hline Olivine & - & - & 1.3 & 0.4 & $1.6^{\mathrm{a}}$ & 1.9 & $1.4^{\mathrm{a}}$ & 2.0 & 0.9 & $3.1^{\mathrm{a}}$ & 2.6 & - & $3.5^{\mathrm{a}}$ & - & 0.4 \\
\hline Orthopyroxene & - & - & - & - & - & - & - & - & - & - & - & - & - & - & - \\
\hline Cr-spinel & - & - & - & - & - & & - & - & - & - & - & - & - & $<<0.1$ & - \\
\hline Magnetite & - & - & - & - & - & - & - & - & - & - & - & - & - & - & - \\
\hline Total phenocrysts & 0.2 & - & 14.7 & 11.5 & 14.8 & 16.9 & 2.9 & 13.1 & 12.7 & 20.4 & 14.8 & 0 & 17.2 & 0 & 17.6 \\
\hline \multicolumn{16}{|l|}{ Groundmass: } \\
\hline Plagioclase & 42.7 & $49.4^{\mathrm{e}}$ & 2.9 & - & 2.2 & 31.8 & 12.9 & 5.1 & 1.5 & 1.2 & 12.1 & 5.0 & - & $47.0^{d}$ & 7.4 \\
\hline Clinopyroxene & 26.7 & $26.0^{\mathrm{C}}$ & 0.8 & - & - & 21.5 & - & - & 0.5 & - & $9.9^{c}$ & 3.0 & - & $27.2^{\mathrm{d}}$ & 21.9 \\
\hline Orthopyroxene & - & - & - & - & - & - & - & - & - & - & - & - & - & - & - \\
\hline Olivine & - & - & - & $<0.1$ & - & 0.2 & - & - & - & - & - & - & - & $4.0^{d}$ & - \\
\hline Opaques & 1.8 & 1.8 & - & - & - & - & - & 0.3 & - & - & - & - & - & 1.0 & \\
\hline Mesostasis & 28.5 & 22.8 & 81.7 & 88.5 & 92.9 & 29.7 & 94.3 & 81.5 & 85.3 & 78.5 & 63.2 & 92.0 & 82.9 & 20.7 & 53.0 \\
\hline Vesicles & 7.1 & 5.3 & 21.3 & - & 18.0 & 10.5 & 23.1 & 13.9 & 15.7 & 8.4 & 14.3 & 30.1 & - & 11.6 & 17.5 \\
\hline Vesicle infilling & 5.6 & 6.2 & - & - & - & - & - & - & - & - & - & - & - & 5.8 & - \\
\hline$N$ & 1276 & 1400 & 1640 & 1725 & 1447 & 1033 & 1102 & 1723 & 1613 & 1931 & 1427 & 1073 & 1721 & 1340 & 1500 \\
\hline
\end{tabular}

Notes: Samples have been recalculated vesicle-free. $N=$ number of points counted.

${ }^{\text {a }}$ Gradation of plagioclase, clinopyroxene, \pm olivine from phenocrystal to microphenocrystal size ranges.

${ }^{\mathrm{b}}$ Phenocrystal to microphenocrystan size, often with clinopyroxene rims.

${ }^{\mathrm{c}}$ Plagioclase seriate textured, mostly relatively coarse groundmass; pyroxene ophitic.

${ }^{\mathrm{d}}$ Seriate texture.

${ }^{\mathrm{e}}$ Seriate textured from microphenocrystal to groundmass size, often in aggregates.

${ }^{\mathrm{f}}$ Coarse groundmass to microphenocrystal size, also as inclusions in clinopyroxene.

the Unit 1 tholeiite, and the groundmass pyroxenes within Units 2 and 9. In addition, these latter two units carry phenocrystal bronzite. The compositions of the pyroxenes in the Site 839 basaltic andesites are, in fact, closely similar to those occurring in the modern Tofua Arc basaltic andesites (fig. 4 in Ewart et al., this volume). Relatively limited pyroxene data are available for the CLSC, ELSC, and Valu Fa lavas (Figs. 4J-4L). These indicate extensive development of subcalcic to low calcium pyroxenes in the ELSC and Valu Fa lavas.

One aspect, therefore, shown by the above mineralogical comparisons is the closer affinity shown by the Site 839 magmas to those of the ELSC, Valu Fa, and especially modern Tofua Arc lavas. A second important aspect concerns the possible role of mixing within the Leg 135 lavas, as shown, for example, by the isotopic and trace element data for Site 834 (Hergt and Nilsson, this volume) and the Cr-spinel data for Units 1 and 3 at Site 839 (Allan, this volume). To investigate possible mineralogical disequilibrium, olivine compositions are plotted (Fig. 5) vs. whole-rock $\mathrm{Mg}$ ratios (atomic $\% \mathrm{Mg} / \mathrm{Mg}+\mathrm{Fe}^{2+}$, where $\mathrm{Fe}_{2} \mathrm{O}_{3} / \mathrm{FeO}$ is assumed equal to 0.2 ). Three sets of $\mathrm{Fe}-\mathrm{Mg}$ partition coefficient ratio curves are plotted for comparison, which encompass the range of plausible "equilibrium" values that may be expected. The results suggest "nonequilibrium" compositions of olivines in Units 1 and 3 from Site 839 , also supported by the data for the single matrix-olivine pair from Unit 3 . Figure 5 also suggests, however, that certain of the sequences within Sites 836 (Unit 4) and 834 (Units 6, 7 , and 9) exhibit olivine compositions not in equilibrium with wholerock values. These data, therefore, certainly lend support to the role of mixing processes in the petrogenesis of certain of the Leg 135 lavas, although the olivine data taken alone do not necessarily preclude such processes as the accumulation of crystals or the occurrence of xenocrystal olivines.

\section{MAJOR ELEMENT DATA}

Figures $6 \mathrm{~A}-6 \mathrm{G}$ illustrate the normative compositions of the Sites 834 to 839 lavas, together with data from the Lau spreading centers, Tonga Arc, and Kermadec Arc, projected from the plagioclase onto the olivine-clinopyroxene-silica plane (after the method of Grove et al., 1982). The inferred phase boundaries are after Grove and Bryan
(1983) and Grove et al. (1982). Comparisons of data in these plots suggest the following points:

1. The lavas from Sites 834 to 838 project either close to, or on, the olivine side of the 1-bar cotectic, consistent with the observed phenocryst assemblages of plagioclase + olivine \pm augite. The consistency with which the data is displaced toward the olivine side of the saturation surface is suggestive of crystallization under significant water pressure (see Gaetani et al., this volume). The most silica-rich samples (including all analyzed samples from Sites 837 to 838 ) are orthopyroxene-bearing, consistent with their projected compositions relative to the orthopyroxene-saturated surface(s). The bulk of the data plot in the silica-saturated field; additional data from glasses and whole rocks (Bryan et al., this volume) also indicate that silicaundersaturated compositions do occur in Site 836.

2. The general compositional fields observed for Sites 834-836 compare closely with the ELSC, CLSC, and KTJ lavas, although the lavas from VF, and to a less extent the ELSC, show a greater predominance toward more silica-enriched compositions, and in this regard may be compared with the modern Tongan and Kermadec axial arc volcanoes. Most of the data exhibit an apparent displacement toward the inferred 1-Kbar water pressure olivine-pyroxene saturation surfaces (Grove et al., 1982).

3. Site 839 is unique with respect to the occurrence of olivinephyric, high-MgO lavas (Units 3, 4, and 6), together with magnesian tholeiite (Unit 1) and basaltic andesites (Units 2, 5, 7, and 9). Petrographic data indicate that Unit 1 lavas are at or close to plagioclase saturation, whereas the bulk compositions of Units 3 and 6 are not, consistent with their projection well within the olivine field. Plagioclase, however, occurs in the groundmass of these lavas, consistent with the projected composition of the separated matrix from one of these lavas (tie-line in Fig. 6B). The basaltic andesites project within the orthopyroxene field, consistent with the occurrence of plagioclase + orthopyroxene + augite phenocryst assemblages. The projected compositions of Units 1 and 2, 5, 7, and 9, which are considered to most closely define the olivine-pyroxene saturation surfaces, are again clearly displaced toward the 1-Kbar water pressure surface, consistent with the experimental data of Gaetani et al. (this volume). 
Table 1 (continued).

\begin{tabular}{|c|c|c|c|c|c|c|c|c|c|c|c|}
\hline Hole: & $837 \mathrm{~B}$ & $837 \mathrm{~B}$ & $838 \mathrm{~A}$ & $839 \mathrm{~B}$ & $839 \mathrm{~B}$ & $839 \mathrm{~B}$ & $839 \mathrm{~B}$ & $839 \mathrm{~B}$ & 839B & 839B & $839 \mathrm{~B}$ \\
\hline Core, section: & $3 R-1$ & $5 R-1$ & $20 \mathrm{H}-1$ & 13R-2 & 20R-1 & 23R-1 & 25R-1 & $25 \mathrm{R}-1$ & $30 \mathrm{R}$ - & $35 R-1$ & $38 \mathrm{R}-1$ \\
\hline Interval $(\mathrm{cm})$ : & $141-145$ & $1-8$ & $70-114$ & $25-30$ & $29-35$ & $0-6$ & $27-32$ & $33-41$ & $79-841$ & $7-11$ & $8-12$ \\
\hline Unit or subunit: & 1 & 1 & (volcanic gravel) & 1 & 3 & 3 & 3 & 3 & 9 & 9 & 9 \\
\hline \multicolumn{12}{|l|}{ Phenocrysts: } \\
\hline Plagioclase & 0.9 & 1.6 & 4.1 & 0.9 & - & - & - & - & 10.5 & 14.8 & 9.4 \\
\hline Clinopyroxenes & 2.7 & 1.1 & 0.5 & $5.1^{\mathrm{a}}$ & $4.8^{\mathrm{a}}$ & $1.1^{\mathrm{a}}$ & 1.2 & 0.3 & 0.6 & 0.1 & 0.4 \\
\hline Olivine & - & - & - & $2.9^{a}$ & $10.9^{a}$ & $16.2^{\mathrm{a}}$ & $14.7^{\mathrm{a}}$ & 27.8 & - & - & - \\
\hline Orthopyroxene & $0.2^{b}$ & $0.1^{\mathrm{b}}$ & 0.3 & - & - & - & - & 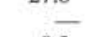 & 0.6 & 0.7 & 0.3 \\
\hline Cr-spinel & - & - & - & 0.1 & 0.2 & 0.2 & 0.2 & 0.3 & - & - & - \\
\hline Magnetite & - & - & 0.5 & - & - & - & - & - & - & - & - \\
\hline Total phenocrysts & 3.8 & 2.8 & 5.4 & 9.0 & 15.9 & 17.5 & 16.1 & 28.4 & 11.7 & 15.6 & 10.1 \\
\hline \multicolumn{12}{|l|}{ Groundmass: } \\
\hline Plagioclase & 23.4 & 18.4 & - & 30.0 & 8.1 & $<0.1$ & 5.4 & 1.4 & 15.3 & 11.5 & 12.5 \\
\hline Clinopyroxene & 12.4 & 10.6 & - & 15.3 & 11.7 & 19.6 & 10.9 & 10.3 & 10.1 & - & 2.9 \\
\hline Orthopyroxene & - & - & - & - & - & - & - & - & - & - & - \\
\hline Olivine & - & - & - & - & - & 0.8 & - & - & - & - & - \\
\hline Opaques & $0.2^{f}$ & $0.2^{f}$ & - & - & - & - & - & - & 0.1 & - & - \\
\hline Mesotasis & 60.1 & 67.9 & 94.6 & 45.5 & 64.2 & 62.1 & 67.7 & 60.0 & 62.8 & 73.0 & 74.6 \\
\hline Vesicles & 13.6 & 11.2 & - & 14.3 & 36.0 & 34.1 & 33.2 & 20.1 & 14.5 & 17.7 & 4.8 \\
\hline Vesicle infilling & - & - & - & - & - & - & - & - & - & - & - \\
\hline $\mathrm{N}$ & 1245 & 1346 & 1497 & 1221 & 1339 & 2066 & 1867 & 1252 & 1328 & 1332 & 1315 \\
\hline
\end{tabular}

It is relevant to compare the high-MgO basalt data from Site 839 with the boninites of northern Tonga (Fig. 6B). Both sets of compositions project into the olivine field at $1 \mathrm{~atm}$., with fractionation of olivine and minor pyroxene evidently controlling compositions toward the olivine + augite + plagioclase saturation surfaces, and thus exhibit comparable major element behavior. The boninites, however, are clearly displaced toward more silica-enriched compositions, even at equivalent projected olivine compositions.

The previous observations are reinforced by considering the data fields in terms of the projection from clinopyroxene onto the plagioclase-olivine-silica surface (Figs. 7A-7D). The fields for the Leg 135 sites (except Site 839) exhibit complete overlap with the total data field for the Tonga-Kermadec volcanoes. In contrast, the fields for the modern Lau spreading centers (Fig. 7B) exhibit greater variability, possibly pressure controlled. Again, however, the compositional fields and trends of the boninites and the Site 839 lavas are distinct.

Further comparisons between the various suites can be made (Figs. $8-11)$ by means of variation diagrams, using $\mathrm{MgO}$ as the major variable, with Figure 8 showing the overall $\mathrm{MgO}$ distributions within the main subregions of the Lau-Tonga-Kermadec region. These data illustrate the overlapping range in $\mathrm{MgO}$ from Sites 834 to 836, with the tholeiites from the latter site extending to slightly higher values than in the lavas from Sites 834 and 835. Lavas from the CLSC, KTJ, and ELSC-ILSC exhibit similar although more variable $\mathrm{MgO}$, which extend to both lower and higher $\mathrm{MgO}$ than Sites 834 to 836 . The Valu $\mathrm{Fa}$ lavas, however, are represented by a higher proportion of lower $\mathrm{MgO}$ and are more fractionated compositions, therefore, consistent with previously presented chemical and mineralogical data.

The Site 839 lavas are again distinctive in terms of $\mathrm{MgO}$, most notably the picritic units, which invite obvious comparison with the northern Tongan boninitic series. The arc-related lavas of the Tonga, Kermadec, and Lau islands all exhibit a similar tendency for a higher proportion of relatively low-MgO types compared to the Lau Basin spreading centers, with the notably exception of the Valu Fa lavas (which exhibit strong arc-like geochemical signatures).

Of the other major elements, variation diagrams of $\mathrm{MgO}$ vs. $\mathrm{CaO}$, $\mathrm{Na}_{2} \mathrm{O}$, and $\mathrm{TiO}_{2}$ are specifically illustrated. These plots emphasize the role of fractional crystallization processes in the evolution of the various magma systems. The $\mathrm{CaO}-\mathrm{MgO}$ relations are chosen as they illustrate well the distinctiveness of the boninites and the Site 839 $\mathrm{MgO}$-rich lava suite. These clearly show increasing $\mathrm{CaO}$ with decreasing $\mathrm{MgO}$, reversing trends only when $\mathrm{MgO}$ levels have dropped to near $7 \%$. This is suggestive of fractionation dominated by olivine \pm orthopyroxene. The other volcanic suites exhibit decreasing $\mathrm{CaO}$ and $\mathrm{MgO}$, although in the cases of the ELSC and ILSC data, indications are that this trend flattens above about $9 \% \mathrm{MgO}$.

Of the major elements, $\mathrm{Na}_{2} \mathrm{O}$ and $\mathrm{TiO}_{2}$ (Figs. 10-11) provide the most distinctive discrimination between the magmatic groups of the region, with both $\mathrm{Na}$ and $\mathrm{Ti}$ exhibiting negative correlations with $\mathrm{MgO}$. At low $\mathrm{MgO}$ contents, $\mathrm{TiO}_{2}$ shows a rapid depletion in some of the volcanic suites (presumably related to $\mathrm{Fe}-\mathrm{Ti}$ oxide precipitation). Considering first the Leg 135 site data, it is evident that the Site 834 lavas are, for given $\mathrm{MgO}$ contents, the most $\mathrm{Na}$ - and Ti-enriched, whereas the Site 839 lavas are the most depleted. Site 835 lavas overlap those of Site 834 , whereas lavas from Sites 836 and 837 are intermediate. The very limited numbered samples from Site 838 suggest that they may extend the trend shown by the Site 839 samples. Although discussion of these differences will be given subsequently in this paper, it is relevant to note here that the differences are inferred to be source related.

Comparison of the Leg 135 data with the modern arc and spreading ridge lavas also reveals some interesting comparisons. For example, although overlap occurs, a pattern is present of increasing $\mathrm{TiO}_{2}$. at given $\mathrm{MgO}$ levels, passing from the VF, through the ELSC, to the CLSC. A similar, but less clearly defined pattern is apparent for $\mathrm{Na}_{2} \mathrm{O}$. For both elements, the Site 834 data show the closest overlap with the CLSC and the KTJ. Comparison of Site 839 with the Tonga and Kermadec lavas suggests overlapping abundances of $\mathrm{Na}_{2} \mathrm{O}$, although the absence of high- $\mathrm{MgO}$ lavas in the modern axial arc volcanoes precludes a more complete comparison. $\mathrm{TiO}_{2}$ is similar between the Kermadec and Site 839 lavas, but the lavas from this latter site are mostly slightly enriched in $\mathrm{TiO}_{2}$ (at given $\mathrm{MgO}$ abundances) compared with the majority of Tongan lavas. The northern Tongan boninites are more $\mathrm{TiO}_{2}$ depleted than the Kermadec and Site 839 lavas, although they overlap with respect to $\mathrm{Na}_{2} \mathrm{O}$ in the Site 839 and modern Tongan lavas.

In summary, the major element data show that apparently continuous spatial and, presumably also, temporal variations of chemistry exist within the lavas of the Lau Basin. Moreover, a set of near-parallel variations are recognizable in the lavas intersected at Sites 834-839. The basaltic andesites of Site 839 have a distinctly arc-like chemistry, whereas the Site 839 high-MgO lavas can perhaps be envisaged as trending toward boninites in their overall chemistry. In contrast, the Site 834 lavas seem to be similar to those of the CLSC, with chemistries close to N-MORB (e.g., see also Loock et al., 1990; Sunkel, 1990; and following discussion). Site 836 glasses also show overlap with ELSC chemistry, although data are limited for Site 836. 
Table 2. New major and trace element analyses of lavas from Site 834.

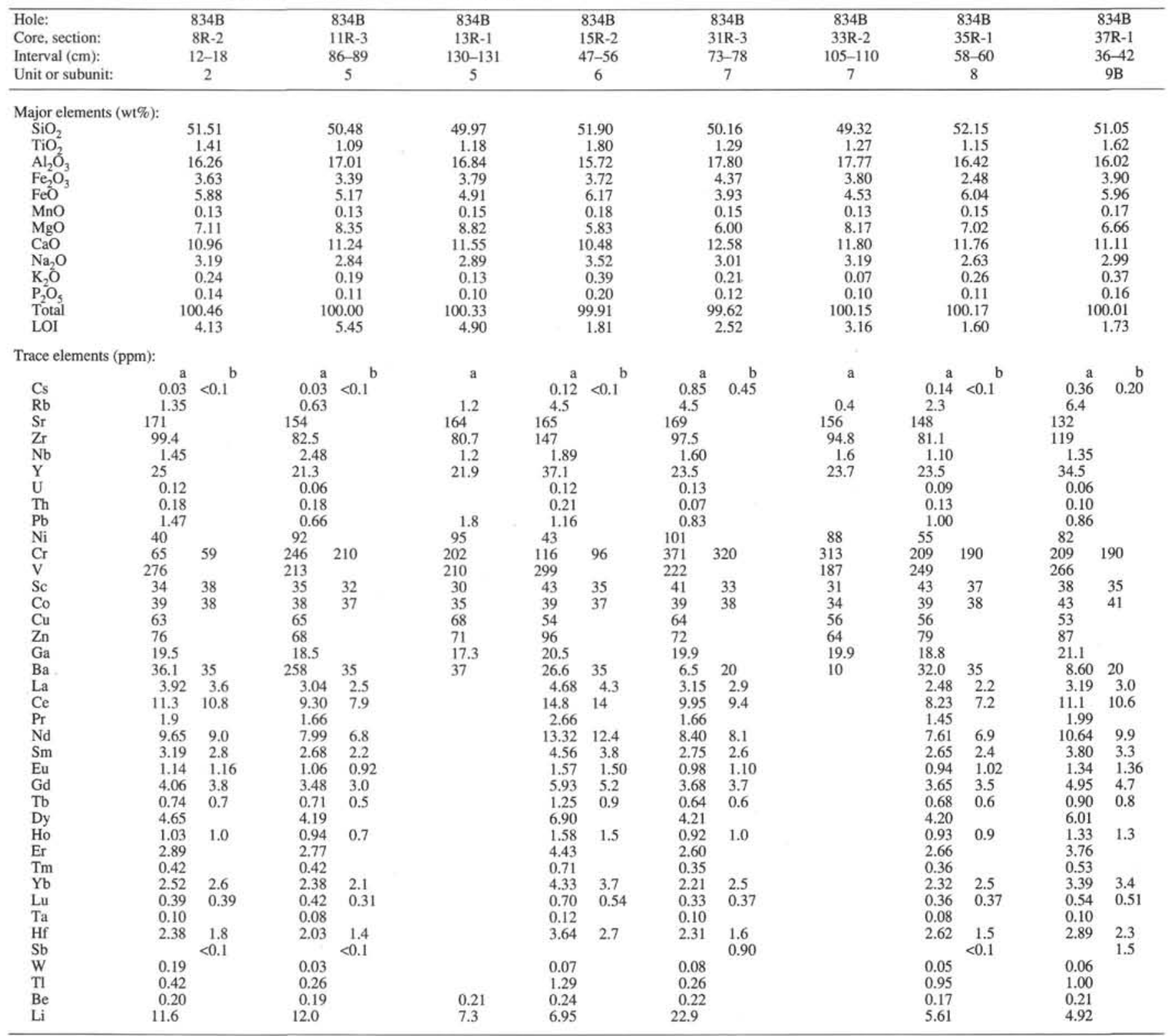

Notes: Major element values (wt\%) were determined by X-ray fluorescence, with $\mathrm{Na}_{2} \mathrm{O}$ determined by atomic absorption. Loss of ignition (LOI) corrected for oxidation of Fe. Trace elements based on the following techniques: Column a: ICP-MS (D. Lambert and W.W. Ahlers, Monash University); X-ray fluorescence (F. Audsley, University of Queensland, specifically $\mathrm{Rb}, \mathrm{Sr}, \mathrm{Zr}, \mathrm{Nb}$ (in part), $\mathrm{Y}, \mathrm{Ni}, \mathrm{Cr}, \mathrm{V}, \mathrm{Sc}, \mathrm{Co}, \mathrm{Cu}, \mathrm{Zn}$, and $\mathrm{Ga}$ ); and atomic absorption with graphite furnace (Be, $\mathrm{Pb}$ ) and flame photometry ( $\mathrm{Li}$ in Tables 3 and 5 ) (R. Hall, University of Queensland). Column b: INAA (B.W. Chappell, Australian National University). Column c: Spark source mass spectrography (R. Rudmick, Research School of Earth Sciences, Australian National University). All trace element values in parts per million (ppm).

\section{TRACE ELEMENT DATA}

\section{Regional Comparisons}

The general abundance patterns of the compatible and incompatible elements are compared in Figures $12-14$. The $\mathrm{Ba}$ and $\mathrm{Zr}-\mathrm{MgO}$ plots (Figs. 12-13) illustrate the incompatible element patterns, with both elements increasing with decreasing $\mathrm{MgO}$, a trend certainly reflecting the overall control by crystal fractionation processes throughout the various subprovinces of the Lau-Tonga system. The differing rates and levels of $\mathrm{Ba}$ and $\mathrm{Zr}$ increase, however, clearly reflect the abundances of these elements in their parental melts. Comparing Site 834 to Site 839 , it is evident that the Ba variation fields for Sites 834-836 overlap, with the higher $\mathrm{MgO}(>6 \%)$ samples having $\mathrm{Ba}$ levels lower than 60 ppm. The lavas from Sites 837 to 839 are characterized, in contrast, by higher $\mathrm{Ba}$ abundances, and at the low $\mathrm{MgO}$ end of their compositional spectrum, fractionate to abundances in excess of $100 \mathrm{ppm}$. The reverse is observed with $\mathrm{Zr}$, in which Site 834 lavas clearly are $\mathrm{Zr}$ enriched at given $\mathrm{MgO}$ abundances, compared with the lavas of other sites, and also fractionate to relatively higher levels. The Site 839 sequence lies at the lower end of the $\mathrm{Zr}$ abundance spectrum. Thus, as with the major element data, evidence can be found for systematic differences in incompatible trace element patterns among the lavas from the six Lau Basin drill sites.

The trace element geochemical patterns for Sites 834-839 are compared with the overall Lau-Tonga arc and modern spreading centers in Figures 12 and 13. It is evident that, with respect to $\mathrm{Ba}$, the modern arc lavas of Tonga and Kermadec are relatively enriched, and 
Table 2 (continued).

\begin{tabular}{|c|c|c|c|c|c|c|}
\hline Hole: & \multicolumn{2}{|c|}{$834 \mathrm{~B}$} & \multicolumn{2}{|c|}{$834 B$} & \multicolumn{2}{|c|}{$834 \mathrm{~B}$} \\
\hline Core, section: & \multicolumn{2}{|c|}{$40 \mathrm{R}-1$} & \multicolumn{2}{|c|}{$55 \mathrm{R}-1$} & \multicolumn{2}{|c|}{$57 \mathrm{R}-1$} \\
\hline Interval $(\mathrm{cm})$ : & \multicolumn{2}{|c|}{$57-60$} & \multicolumn{2}{|c|}{$23-25$} & \multicolumn{2}{|c|}{$126-128$} \\
\hline Unit or subunit: & \multicolumn{2}{|c|}{$10 \mathrm{~A}$} & \multicolumn{2}{|r|}{12} & & 13 \\
\hline \multicolumn{7}{|c|}{ Major elements (wt\%): } \\
\hline $\mathrm{SiO}_{2}$ & \multicolumn{2}{|c|}{52.49} & \multicolumn{2}{|c|}{51.97} & & 51.41 \\
\hline $\mathrm{TiO}_{2}^{2}$ & \multicolumn{2}{|c|}{$\begin{array}{r}52.49 \\
1.66\end{array}$} & \multicolumn{2}{|c|}{2.16} & & 1.19 \\
\hline $\mathrm{Al}_{2} \mathrm{O}_{3}$ & & .56 & & 15.68 & & 6.68 \\
\hline $\mathrm{Fe}_{2} \mathrm{O}_{3}$ & & .72 & & 6.07 & & 2.89 \\
\hline $\mathrm{FeO}^{3}$ & & .86 & & 6.95 & & 5.92 \\
\hline $\mathrm{MnO}$ & & 18 & & 0.22 & & 0.16 \\
\hline $\mathrm{MgO}$ & & .57 & & 4.02 & & 7.24 \\
\hline $\mathrm{CaO}$ & & 41 & & 8.31 & & 1.91 \\
\hline $\mathrm{Na}_{2} \mathrm{O}$ & & .37 & & 3.84 & & 2.70 \\
\hline $\mathrm{K}_{2} \mathrm{O}$ & & 69 & & 0.61 & & 0.19 \\
\hline $\mathrm{P}_{2} \mathrm{O}_{5}$ & & .19 & & 0.22 & & 0.11 \\
\hline Total & & .70 & & 00.05 & & 0.40 \\
\hline LOI & & .71 & & 3.22 & & 1.5 \\
\hline Trace elements & & & & & & \\
\hline & a & b & $\mathrm{a}$ & b & a & b \\
\hline Cs & 0.30 & 0.15 & 0.21 & $<0.1$ & 0.09 & $<0.1$ \\
\hline $\mathrm{Rb}$ & 8.2 & & 9.1 & & 0.94 & \\
\hline $\mathrm{Sr}$ & 175 & & 180 & & 154 & \\
\hline $\mathrm{Zr}$ & 110 & & 143 & & 81.8 & \\
\hline $\mathrm{Nb}$ & 1.21 & & 1.55 & & 0.91 & \\
\hline $\mathrm{Y}$ & 31.3 & & 38.4 & & 23.2 & \\
\hline $\mathrm{U}$ & 0.15 & & 0.09 & & 0.08 & \\
\hline Th & 0.27 & & 0.14 & & 0.28 & \\
\hline $\mathrm{Pb}$ & 1.78 & & 1.44 & & 1.24 & \\
\hline $\mathrm{Ni}$ & 21 & & 6.5 & & 61 & \\
\hline $\mathrm{Cr}$ & 13 & 7 & 7 & 3 & 217 & 200 \\
\hline $\mathrm{V}$ & 352 & & 413 & & 255 & \\
\hline $\mathrm{Sc}$ & 33 & 29 & 33 & 31 & 43 & 38 \\
\hline Co & 37 & 36 & 40 & 40 & 39 & 37 \\
\hline $\mathrm{Cu}$ & 29 & & 31 & & 57 & \\
\hline $\mathrm{Zn}$ & 100 & & 126 & & 80 & \\
\hline $\mathrm{Ga}$ & 20.1 & & 24.4 & & 16.6 & \\
\hline $\mathrm{Ba}$ & 48.2 & 45 & 46.3 & 55 & 28.8 & 35 \\
\hline $\mathrm{La}$ & 3.94 & 3.6 & 4.62 & & 2.85 & 2.5 \\
\hline $\mathrm{Ce}$ & 12.05 & 11.0 & 14.65 & 13.8 & 8.55 & 8.1 \\
\hline Pr & 2.10 & & 2.58 & & 1.71 & \\
\hline $\mathrm{Nd}$ & 10.93 & 9.8 & 13.3 & 13.0 & 8.3 & 7.5 \\
\hline $\mathrm{Sm}$ & 3.80 & 3.2 & 4.44 & 4.1 & 3.10 & 2.6 \\
\hline $\mathrm{Eu}$ & 1.31 & 1.32 & 1.61 & 1.65 & 1.23 & 1.08 \\
\hline $\mathrm{Gd}$ & 4.86 & 4.4 & 5.94 & 5.5 & 4.00 & 3.6 \\
\hline $\mathrm{Tb}$ & 0.86 & 0.7 & 1.04 & 0.9 & 0.86 & 0.7 \\
\hline Dy & 5.70 & & 6.90 & & 4.84 & \\
\hline Ho & 1.26 & 1.3 & 1.54 & 1.5 & 1.14 & 1.0 \\
\hline Er & 3.57 & & 4.35 & & 3.24 & \\
\hline $\mathrm{Tm}$ & 0.50 & & 0.60 & & 0.55 & \\
\hline $\mathrm{Yb}$ & 3.21 & 3.3 & 3.93 & 4.1 & 2.67 & 2.6 \\
\hline $\mathrm{Lu}$ & 0.51 & 0.48 & 0.62 & 0.61 & 0.55 & 0.39 \\
\hline $\mathrm{Ta}$ & 0.12 & & 0.13 & & 0.07 & \\
\hline Hf & 2.83 & 2.1 & 3.68 & 2.8 & 2.01 & 1.5 \\
\hline $\mathrm{Sb}$ & & 0.10 & & $<0.1$ & & $<0.1$ \\
\hline W & 0.09 & & 0.13 & & 0.07 & \\
\hline $\mathrm{Tl}$ & 2.58 & & 4.11 & & 0.75 & \\
\hline $\mathrm{Be}$ & 0.20 & & 0.21 & & 0.23 & \\
\hline $\mathrm{Li}$ & 8.24 & & 6.49 & & 4.09 & \\
\hline
\end{tabular}

fractionate (at lowest $\mathrm{MgO}$ ) to concentrations in excess of $300 \mathrm{ppm}$. Interestingly, there are some systematic differences between the southernmost Tonga arc volcano of 'Ata and the remaining Tongan lavas, with the 'Ata lavas being more Ba enriched at given MgO levels. Such differences extend to other trace elements. Moreover, a significant overlap is evident between the modern Tonga and the Site $839 \mathrm{Ba}-\mathrm{MgO}$ data. Within the Lau Basin itself, it is evident that Valu Fa and KTJ lavas are Ba enriched compared to the CLSC and ELSC lavas.

Reference to the $\mathrm{Zr}-\mathrm{MgO}$ data reveals complementary comparisons, with the modern arc lavas relatively $\mathrm{Zr}$ depleted, and the CLSC and ELSC lava relatively $\mathrm{Zr}$ enriched. The Valu Fa and King's Triple Junction are intermediate in their abundance patterns, overlapping those of Sites 835-838. Overlap occurs between Site 834 and CLSC lavas, whereas Sites $835-838$ overlap with the ELSC and Valu Fa fields.

Finally, it is relevant to compare the incompatible element patterns between the Tongan axial volcanics, the north Tongan boninites, and the Site 839 olivine-phyric, highly magnesian lavas (most especially Unit 3). In terms of $\mathrm{Zr}$, the two groups of Tonga lavas are closely comparable; however, with the boninites, they are more enriched in $\mathrm{Ba}$.
Compared with Site 839, the boninites are depleted in $\mathrm{Zr}$ (although with some slight overlap) but much more enriched in $\mathrm{Ba}$.

In summary, it is evident that the abundance patterns for $\mathrm{Zr}$ and $\mathrm{Ba}$, although clearly affected by fractional crystallization processes, are nevertheless distinct within the various subprovinces of the arc-backarc system. In particular, the extremes of the compositional spectra occur in the CLSC at the one end, and the modern arc lavas at the other end, with the ELSC, Valu Fa, and King's Triple junction lavas lying at intermediate points. Significantly, parallel variations are seen within the Sites 834-839 data, with Site 834 lavas similar to the CLSC lavas, and Site 839 lavas showing closest similarities to the modern arc lavas and the north Tonga boninites. These differences are consistent with the regional variations shown by especially $\mathrm{Na}_{2} \mathrm{O}$ and $\mathrm{TiO}_{2}$.

Compatible element behavior (Fig. 14) is illustrated by $\mathrm{Ni}$ and serves to emphasize the effects of fractionation. Thus, Ni ranges from relatively high concentrations ( $>300 \mathrm{ppm}$ ) to depleted abundances in the most fractionated magmas, all suites exhibiting continuous ranges of variation. The $\mathrm{Ni}$ abundances correlate with $\mathrm{MgO}$, the highest abundances occurring in the more abundant magnesian lavas of the CLSC and ELSC, the boninites, and Site 839 lavas of Unit 3. The Ni-MgO fractionation trends for these lavas follow similar trajectories that are clearly olivine dominated. The generally less magnesian lavas of the active arc volcanoes and Valu Fa, however, seem to represent the terminations of somewhat shallower $\mathrm{Ni}-\mathrm{MgO}$ fractionation trends, possibly indicative of the more important role of clinopyroxene during fractionation. If so, this implies higher pressure fractionation in comparison with the CLSC and ELSC magmas, but the possibility that these could also represent mixing trends cannot be excluded.

Although not shown, covariance between $\mathrm{TiO}_{2}$ and $\mathrm{V}$ exists and seems to reflect the control of both the concentration and depletion by the specific stages of Fe-Ti oxide precipitation. In the Lau-Tonga lavas, the oxides evidently precipitate at relatively advanced stages of the fractionation processes, with the basaltic and basaltic andesites typically being free of phenocrystal and microphenocrystal oxide phases, excepting $\mathrm{Cr}$-spinel.

\section{Composite Trace Element Comparisons}

The previous major and trace data serve to emphasize the systematic regional patterns of geochemical variation, both within the backarc basin, and also within the arc volcanoes themselves. In Figures 15-19, therefore, a series of spidergrams are shown enabling more general geochemical comparisons to be made between the lavas of Sites $834-839$, the Lau Basin spreading centers (plus the subaerial Ocean Island Basalt (OIB) volcano of Niuafo'ou), the modern Tongan arc volcanoes, the north Tonga boninites, the Kermadec axial volcanoes, and the Lau islands. The spidergrams have been compiled for all data available for each subprovince considered, and are normalized to the $\mathrm{N}-\mathrm{MORB}$ values of Sun and McDonough (1989). Also shown are the averaged normalized values for N-MORB given by Hofmann (1988), these being based on a subset of slightly less magnesian samples $(7.58 \% \mathrm{MgO})$ compared to the Sun and McDonough values, and the minimum N1-MORB values of Viereck et al. (1989). These three sets of values thus give some indication of the range of variation of typical N-MORB abundance patterns, an important factor when comparing other data sets with average MORB data. Data sets illustrated in the various spidergrams have utilized the more $\mathrm{Mg}$-rich samples from each subprovince to attempt to minimize superimposed fractionation effects such that no samples with $<4 \% \mathrm{MgO}$ are included. Although not a highly stringent filter, the relatively fractionated chemistries of the arc lavas make a higher level of $\mathrm{MgO}$ discrimination impractical. This criterion, however, excludes data from Sites 837 and 838 .

Comparison of the Leg 135 site data (Fig. 15) further suggests progressive changes from the Site 834 lavas, which are relatively "N-MORB-like," through Sites 836 and 835 and 839, the latter sequences exhibiting the marked depletions of HFSEs, together with LILE enrichments characteristic of arc lavas. Even the Site 834 data, 
Table 3. New major and trace element analyses of lavas from Sites $\mathbf{8 3 5}$ to $\mathbf{8 3 8}$.

\begin{tabular}{|c|c|c|c|c|c|c|c|c|c|c|c|c|c|c|}
\hline Hole: & \multicolumn{2}{|r|}{$835 \mathrm{~B}$} & \multicolumn{2}{|c|}{$835 \mathrm{~B}$} & $835 B$ & \multicolumn{2}{|c|}{$836 \mathrm{~A}$} & $836 \mathrm{~A}$ & $836 \mathrm{~A}$ & & $836 \mathrm{~A}$ & $836 \mathrm{~B}$ & & $836 \mathrm{~B}$ \\
\hline Core, section: & \multicolumn{2}{|r|}{$4 \mathrm{R}-1$} & \multicolumn{2}{|c|}{$7 \mathrm{R}-1$} & $7 \mathrm{R}-2$ & \multicolumn{2}{|c|}{$3 \mathrm{H}-3$} & $3 \mathrm{H}-3$ & $3 \mathrm{H}-4$ & & $4 \mathrm{H}-\mathrm{CC}$ & $5 R-2$ & & $6 \mathrm{R}-1$ \\
\hline Interval $(\mathrm{cm})$ : & \multicolumn{2}{|c|}{$134-141$} & \multicolumn{2}{|c|}{$15-22$} & $75-84$ & \multicolumn{2}{|c|}{$30-90$} & $33-43$ & $88-100$ & & $0-13$ & $65-74$ & & $105-110$ \\
\hline Unit or subunit: & \multicolumn{2}{|r|}{1} & \multicolumn{2}{|c|}{1} & 1 & \multicolumn{2}{|c|}{1} & 1 & 2 & & 3 & $4 \mathrm{~B}$ & & $4 \mathrm{~B}$ \\
\hline Major elements & t\%): & & & & & & & & & & & & & \\
\hline $\mathrm{SiO}_{2}$ & & 50.45 & & & 50.80 & & & 55.51 & 57.03 & & 49.49 & 49.45 & & 49.13 \\
\hline $\mathrm{TiO}_{2}^{2}$ & & 0.96 & & & 1.04 & & & 1.35 & 1.21 & & 0.81 & 0.83 & & 0.71 \\
\hline $\mathrm{Al}_{2} \mathrm{O}_{3}$ & & 16.13 & & & 15.52 & & & 14.95 & 14.70 & & 16.36 & 15.95 & & 16.80 \\
\hline $\mathrm{Fe}_{2} \mathrm{O}_{3}$ & & 3.11 & & & 4.15 & & & 2.94 & 2.78 & & 2.00 & 3.58 & & 2.90 \\
\hline $\mathrm{FeO}^{3}$ & & 6.36 & & & 5.75 & & & 9.45 & 8.93 & & 6.65 & 5.28 & & 5.40 \\
\hline $\mathrm{MnO}$ & & 0.16 & & & 0.13 & & & 0.20 & 0.26 & & 0.16 & 0.15 & & 0.14 \\
\hline $\mathrm{MgO}$ & & 7.66 & & & 8.19 & & & 3.98 & 3.65 & & 9.09 & 9.59 & & 9.68 \\
\hline $\mathrm{CaO}$ & & 12.39 & & & 11.43 & & & 8.45 & 8.12 & & 13.43 & 13.51 & & 13.11 \\
\hline $\mathrm{Na}_{2} \mathrm{O}$ & & 2.13 & & & 2.59 & & & 3.39 & 3.26 & & 2.03 & 2.17 & & 2.10 \\
\hline $\mathrm{K}_{2} \mathrm{O}$ & & 0.23 & & & 0.12 & & & 0.23 & 0.28 & & 0.07 & 0.05 & & 0.05 \\
\hline $\mathrm{P}_{2} \mathrm{O}_{5}$ & & 0.08 & & & 0.07 & & & 0.13 & 0.13 & & 0.05 & 0.04 & & 0.04 \\
\hline Total & & 99.66 & & & 99.79 & & & 100.58 & 100.35 & & 100.14 & 100.60 & & 100.05 \\
\hline LOI & & 1.86 & & & 3.00 & & & 1.68 & 2.06 & & 1.15 & 3.21 & & 4.21 \\
\hline Trace elements ( & m): & & & & & & & & & & & & & \\
\hline & a & b & a & b & a & a & b & a & a & a & b & a & a & b \\
\hline Cs & 0.09 & $<0.1$ & 0.11 & $<0.1$ & & 0.15 & 0.10 & & & 0.01 & $<0.1$ & & 0.01 & $<0.1$ \\
\hline $\mathrm{Rb}$ & 2.4 & & 2.6 & & 1.9 & 4.7 & & 2.7 & 4.4 & 1.8 & & 1.0 & 1.2 & \\
\hline $\mathrm{Sr}$ & 127 & & 123 & & 123 & 132 & & 136 & 134 & 136 & & 136 & 140 & \\
\hline $\mathrm{Zr}$ & 44.4 & & 43.5 & & 47.7 & 70.8 & & 71.6 & 76.9 & 42.6 & & 39.5 & 36.9 & \\
\hline $\mathrm{Nb}$ & 0.52 & & 0.49 & & 0.7 & 1.00 & & 1.6 & 2.1 & 0.45 & & 0.95 & 0.41 & \\
\hline $\mathrm{Y}$ & 21.8 & & 21.5 & & 21.9 & 28.1 & & 30.4 & 32.5 & 17.6 & & 16.6 & 14.9 & \\
\hline $\mathrm{U}$ & 0.06 & & 0.08 & & & 0.11 & & & & 0.04 & & & 0.05 & \\
\hline Th & 0.11 & & 0.18 & & & 0.10 & & & & 0.00 & & & 0.005 & \\
\hline $\mathrm{Pb}$ & 0.72 & & 0.77 & & 1.0 & 1.23 & & & 1.4 & 0.93 & & 0.94 & 1.39 & \\
\hline $\mathrm{Ni}$ & 64 & & 65 & & 58 & 14 & & 11 & 13 & 109 & & 95 & 116 & \\
\hline $\mathrm{Cr}$ & 192 & 180 & 190 & 190 & 108 & 15 & 13 & 10 & 4 & 384 & 330 & 254 & 371 & 340 \\
\hline V & 278 & & 274 & & 289 & 427 & & 431 & 389 & 251 & & 248 & 218 & \\
\hline Sc & 44 & 39 & 41 & 40 & 33 & 43 & 37 & 40 & 40 & 50 & 42 & 30 & 40 & 41 \\
\hline $\mathrm{Co}$ & 43 & 41 & 43 & 42 & 36 & 38 & 37 & 31 & 34 & 46 & 45 & 41 & 45 & 43 \\
\hline $\mathrm{Cu}$ & 68 & & 65 & & 85 & 104 & & 109 & 120 & 86 & & 108 & 79 & \\
\hline $\mathrm{Zn}$ & 81 & & 82 & & 97 & 112 & & 113 & 112 & 67 & & 69 & 53 & \\
\hline $\mathrm{Ga}$ & 19.5 & & 20.8 & & 20.8 & 20.0 & & 20.0 & 20.2 & 17.2 & & 17.0 & 16.7 & \\
\hline $\mathrm{Ba}$ & 27.6 & 35 & 26.1 & 30 & 46 & 63.7 & 50 & 65 & 79 & 7.93 & 20 & 19 & 7.99 & 10 \\
\hline $\mathrm{La}$ & 2.00 & 2.1 & 2.36 & 1.9 & & 2.91 & 2.7 & & & 0.7 & 1.5 & & 1.01 & 1.3 \\
\hline $\mathrm{Ce}$ & 5.15 & 5.2 & 6.07 & 5.1 & & 9.05 & 7.7 & & & 2.18 & 4.4 & & 3.24 & 3.7 \\
\hline $\mathrm{Pr}$ & 0.94 & & 1.16 & & & 1.70 & & & & 0.44 & & & 0.63 & \\
\hline $\mathrm{Nd}$ & 5.07 & 4.5 & 6.5 & 4.7 & & 9.41 & 7.2 & & & 2.68 & 3.9 & & 3.61 & 2.7 \\
\hline $\mathrm{Sm}$ & 1.97 & 1.9 & 2.50 & 1.9 & & 3.27 & 2.6 & & & 0.9 & 1.5 & & 1.24 & 1.3 \\
\hline $\mathrm{Eu}$ & 0.76 & 0.84 & 0.97 & 0.84 & & 1.19 & 1.09 & & & 0.37 & 0.70 & & 0.52 & 0.60 \\
\hline $\mathrm{Gd}$ & 2.69 & 3.1 & 3.55 & 2.9 & & 4.27 & 4.2 & & & 1.31 & 2.2 & & 1.77 & 1.9 \\
\hline $\mathrm{Tb}$ & 0.49 & 0.6 & 0.67 & 0.6 & & 0.80 & 0.7 & & & 0.26 & 0.5 & & 0.34 & 0.4 \\
\hline Dy & 3.27 & & 4.35 & & & 5.05 & & & & 1.76 & & & 2.19 & \\
\hline Ho & 0.71 & 0.8 & 0.92 & 0.8 & & 1.14 & 1.1 & & & 0.4 & 0.7 & & 0.49 & 0.5 \\
\hline Er & 2.01 & & 2.69 & & & 3.25 & & & & 1.14 & & & 1.4 & \\
\hline $\mathrm{Tm}$ & 0.30 & & 0.40 & & & 0.47 & & & & 0.15 & & & 0.19 & \\
\hline $\mathrm{Yb}$ & 1.97 & 2.4 & 2.68 & 2.5 & & 3.10 & 3.3 & & & 0.98 & 1.9 & & 1.23 & 1.6 \\
\hline $\mathrm{Lu}$ & 0.29 & 0.36 & 0.43 & 0.37 & & 0.50 & 0.50 & & & 0.16 & 0.29 & & 0.2 & 0.25 \\
\hline $\mathrm{Ta}$ & 0.03 & & 0.04 & & & 0.07 & & & & 0.03 & & & 0.03 & \\
\hline $\mathrm{Hf}$ & 1.12 & 1.0 & 1.24 & 1.0 & & 1.96 & 1.6 & & & 1.18 & 0.8 & & 1.00 & 0.6 \\
\hline $\mathrm{Sb}$ & & 0.15 & & 0.10 & & & $<0.1$ & & & & $<0.1$ & & & $<0.1$ \\
\hline W & 0.04 & & 0.05 & & & 0.09 & & & & 0.04 & & & 0.02 & \\
\hline $\mathrm{Tl}$ & 0.28 & & 0.19 & & & 0.57 & & & & 0.2 & & & 0.22 & \\
\hline $\mathrm{Be}$ & 0.19 & & 0.16 & & 0.22 & 0.16 & & & 0.26 & 0.17 & & 0.19 & 0.17 & \\
\hline $\mathrm{Li}$ & 6.3 & & 6.46 & & 8.1 & 6.02 & & & 6.9 & 4.6 & & 5.6 & 8.7 & \\
\hline
\end{tabular}

Note: See Table 2 for explanation of terms.

however, do contain slightly enriched alkali, $\mathrm{Ba}, \mathrm{Sr}$, and $\mathrm{Pb}$ abundances, and slightly depleted $\mathrm{Nb}$ and Ta compared to N-MORB. The status of the $\mathrm{Pb}$ data is uncertain, possibly reflecting slight inconsistency in $\mathrm{Pb}$ analyses (cf. Appendix), whereas the higher alkali abundances, at least in part, reflect mild low-temperature alteration within some of the lavas (see Parson, Hawkins, Allan, et al., 1992). The overall data for Site 834 are interpreted to be consistent with a chemistry similar to, but not exactly comparable with N-MORB. Hergt and Nilsson (this volume), in their detailed study of Site 834, show that significant trace element variation exists between the units, with Unit 7 being in fact closest to N-MORB. The lavas from the other sites, however, more clearly deviate from N-MORB, this being least for Sites 835 and 836 and greatest for Site 839 .

Comparison of the data for Sites 834-839 with the Lau Basin spreading centers (Fig. 16) again shows systematic differences and similarities. Thus, the CLSC and ELSC lavas are clearly closest to $\mathrm{N}-\mathrm{MORB}$ in chemistry, but exhibit some alkali, and possibly $\mathrm{Pb}$, enrichment, and a trend toward slight HFSE depletion; they are generally comparable to Sites 834-836. The Valu Fa data, however, are distinct and strongly arc-like. The KTJ lavas from northeast Lau are similar to N-MORB for all elements except the alkalis, which also are enriched, whereas the Niuafo' ou lavas have similarly enhanced alkali, $\mathrm{Ba}$, and $\mathrm{Pb}$ abundances. In many respects, however, this oceanic island volcano is surprisingly MORB-like in its geochemistry (e.g., see also Reay et al., 1974).

The comparative abundance patterns from Tonga (Fig. 17) show the classic arc-type patterns, extending also to the north Tonga boninites. It is evident, however, even from the qualitative comparison of the patterns, that differences exist in the relative depletion of the elements from $\mathrm{Zr}$ to Lu. Thus, the lavas from the northernmost volcano, Tafahi, are exceptionally depleted, similar to those of the more extreme boninite compositions. The lavas from 'Ata (southernmost Tongan volcano), Tofua, and Kao are the least depleted with respect to these same elements. There is certainly an indication that the more northerly volcanoes in the modern Tonga Arc are geochemically most strongly depleted with respect to HFSEs and the middle- and heavy-rare-earth elements (MREEs and HREEs). Figure 18 compares available data from the Kermadec islands, which have been divided into three major island groups. As was recognized by Ewart and Hawkesworth (1987), the southernmost Kermadec Island of L'Esperance is most MORB- 
Table 3 (continued).

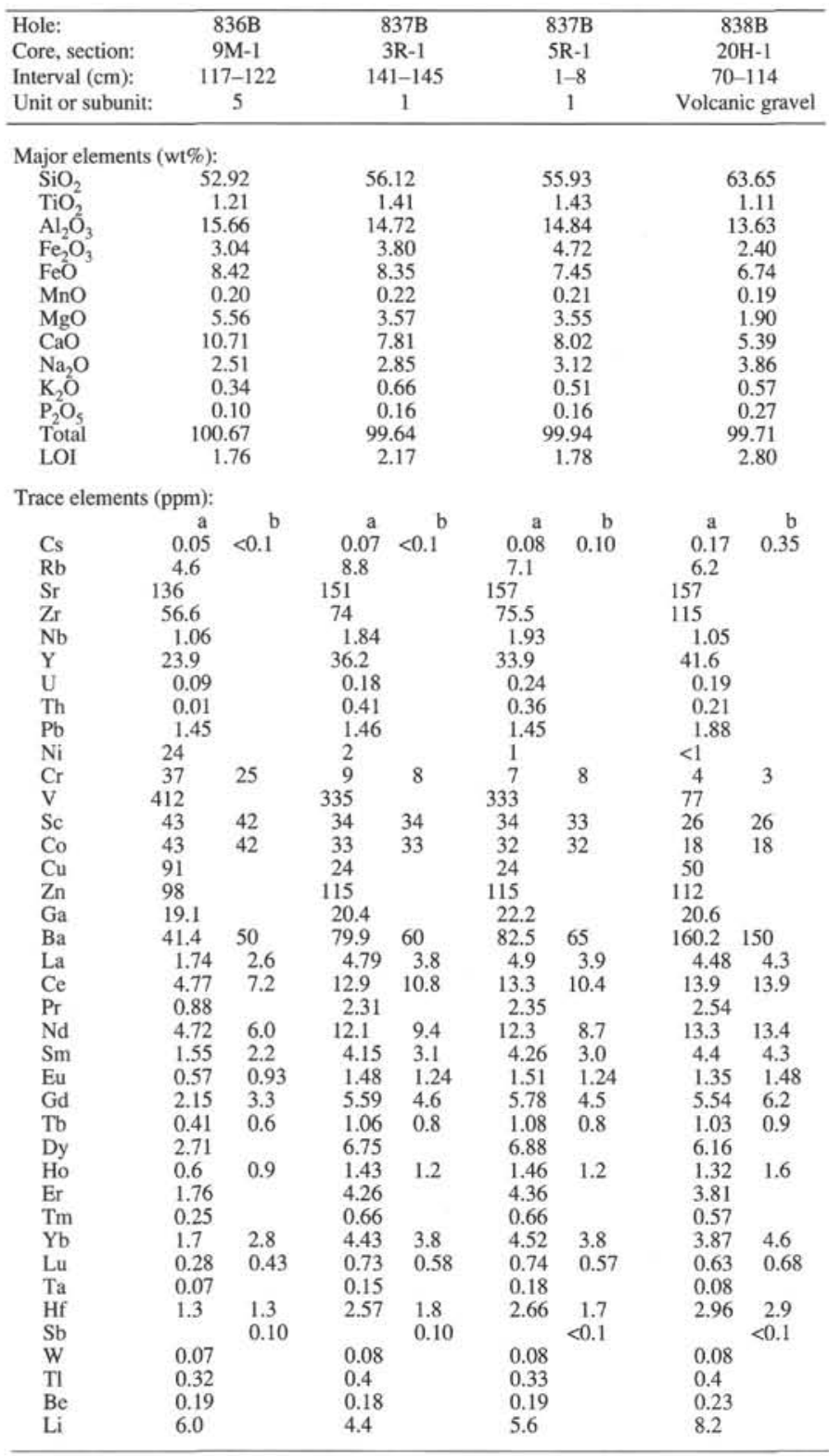

like, but the characteristic arc-like HFSE depletions are still present. The islands of the Raoul Group and Macauley are comparable to the Tonga lavas in their overall geochemical abundance patterns, although they demonstrate a relatively wide range of abundances. These are greater than is readily explained by crystal fractionation alone (e.g., Ewart and Hawkesworth, 1987) and is suggestive of more heterogeneous magma sources than is characteristic of Tonga, an observation consistent with $\mathrm{Pb}$-isotopic compositions (e.g., Oversby and Ewart, 1972).

The final spidergram comparison (Fig. 19) appropriate in the context of the broad regional geochemical patterns being considered here is for the Lau Islands, which form the western boundary to the Lau-Tonga system. There are two distinct arc-like phases of volcanicity on these islands: the earlier widespread Lau Volcanic Group (LVG; 14.0-5.4 Ma), and the more restricted Korobasaga Volcanic Group (KVG: 4.4-2.4 Ma) (Cole et al., 1985, 1990). The youngest volcanics (Mago Volcanic Group; 2.0-0.3 Ma) comprise a more alkaline basalthawaiite association, geochemically and isotopically unrelated to the earlier volcanic phases, and not considered further in this report.

The spidergrams from the Lau and Korobasaga groups exhibit typical arc-like patterns, with extreme HFSE depletions that are more clearly developed in the Korobasaga lavas. Compared to Tonga and the northern Kermadec islands, however, the Lau and Korobasaga volcanics do not exhibit the same degrees of HFSE, MREE, and HREE depletion, an observation that applies also to comparisons with the Site 839 and Valu Fa data.

\section{Rare-earth Elements}

In view of the evidence pointing to the existence of lava compositions extending from N-MORB-like to arc-like within the Lau Basin, it is relevant to compare the REE data for the basalts from the Leg 135 sites with those of the modern Tonga-Kermadec lavas (Fig. 20).

The Site 834 REE patterns are clearly distinct from those of the remaining sites, being typically N-MORB-like with LREE depletion, and with abundances of MREEs to HREEs between $15 \times$ and $25 \times$ chondritic. In contrast, Site 839 data have clearly lower REE abundances $(5 x-12 \times$ chondritic) and flat to LREE-depleted patterns. Such patterns are comparable with those of the arc volcanoes, which vary from the very strongly depleted patterns of Tafahi (north Tonga) to the near N-MORB-like patterns of L'Esperance (southern Kermadec islands). Within the arc lavas, there is again a tendency for the more northerly volcanoes in both the Tonga and Kermadec arc segments to exhibit the most depleted REE abundance patterns. In the case of the Tonga Arc, the lavas from Kao are conspicuously the least depleted.

Within the Lau Basin Leg 135 sites, the lavas from Sites 835 and 836 are also noteworthy for exhibiting LREE depletion and relatively low total REE abundances, especially pronounced in Site 836. These features are consistent, therefore, with the somewhat transitional spidergram patterns described above.

The REE data for the more silicic lava types are illustrated (Fig. $20 \mathrm{G})$, the generally relatively low abundances reflecting the depleted parental abundances, and the lack of LREE enrichment reflecting both the parental LREE depletions and the phase assemblages involved in the fractionation processes controlling the evolution of these magmas (Ewart and Hawkesworth, 1987).

\section{DISCUSSION \\ Introduction}

We have attempted to bring together all available chemical data from the modern Lau Basin spreading centers, the Lau Ridge, the modern Tonga and Kermadec arc volcanoes, and the north Tonga boninites. The primary reason for this synthesis is to put the Leg 135 site data into the proper perspective for the overall regional geochemistry. Perhaps one of the most critical observations is that the geochemical variations and affinities of the lavas sampled at Sites 834-839 can be equated to the lavas erupted either in the various Lau Basin spreading centers and/or by the modern arc volcanoes on the Tonga-Kermadec Ridges. Moreover, the observed differences in the overall geochemical variations observed across the Lau Basin, and along the arc ridges, are inferred to be characteristics inherited from source, although clearly the absolute abundances have been modified by superimposed crystal fractionation and mixing processes. Thus, the regional variations in chemistry imply a strongly heterogeneous LauTonga-Kermadec upper mantle.

In a study of the petrogenesis of the Tonga-Kermadec magmas, Ewart and Hawkesworth (1987) identified two main factors thought to be responsible for the inferred heterogeneity of the mantle wedge beneath the arc volcanoes.

1. The development of relatively refractory peridotitic sources as a result of prior depletion (or multistage depletion) by previous magma extraction(s). These would be equivalent to the second and even third stage melts of Duncan and Green (1987). Experimental data relevant to the nature of such melts is given by Falloon et al. (1988). The development of such refractory source(s) is thought to be 
Table 4. New major and trace element analyses of lavas from Site 839.

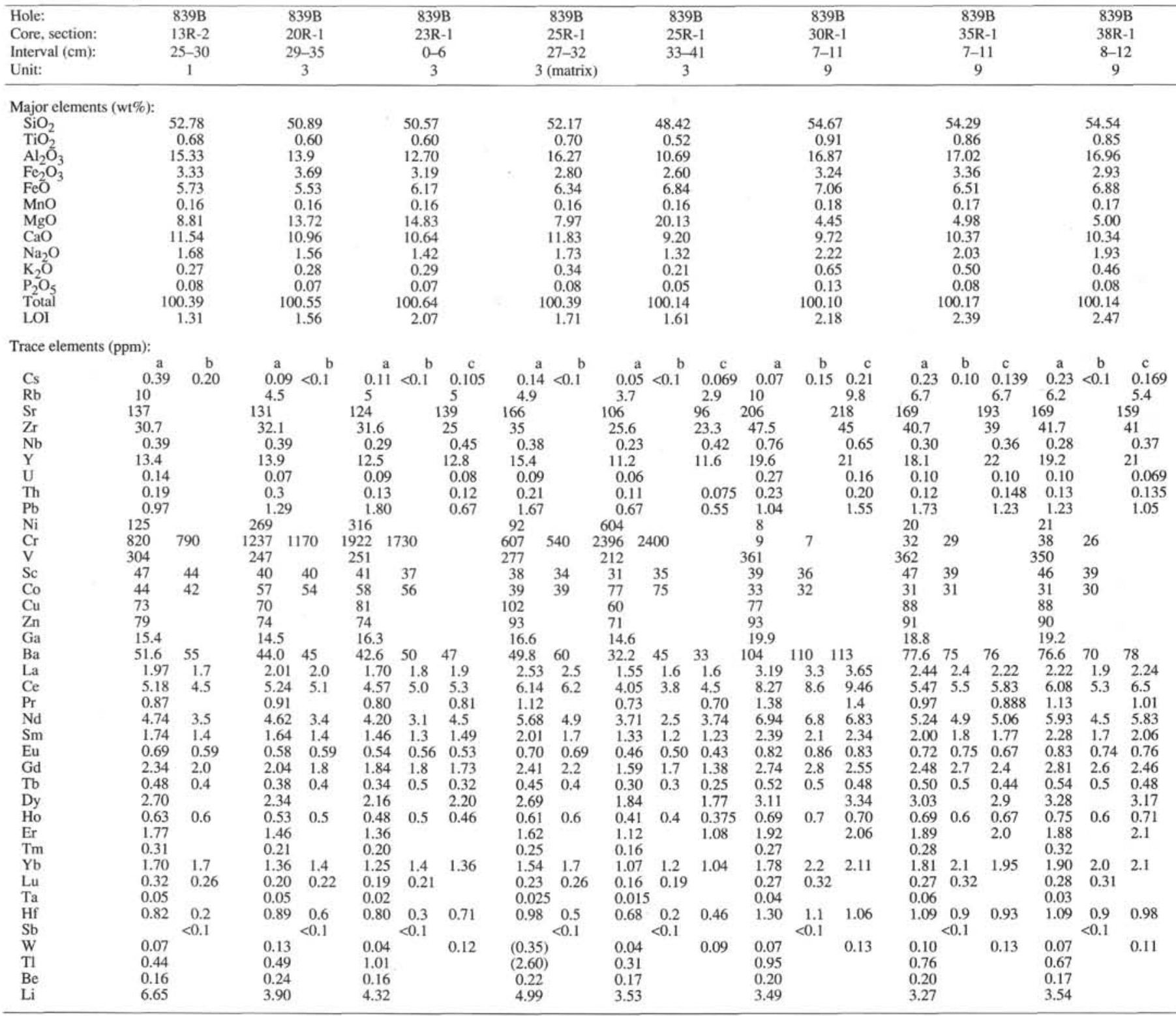

Note: See Table 2 for explanation of terms.

primarily responsible here for the depletions of immobile HFSEs such as $\mathrm{Zr}, \mathrm{Hf}, \mathrm{Nb}, \mathrm{Ta}, \mathrm{Ti}$, and REEs, plus also LILEs. The phases of multistage melt extraction are specifically linked to the coupled backarcarc dynamic systems.

2. Modification of this mantle wedge by replenishment (addition) of "mobile" LILEs (e.g., K, Rb, Cs, Sr, Ba, Pb, and U) derived from dehydration reactions within the subducting slab. Moreover, the imprints of such mantle wedge "metasomatism" will be enhanced by prior depletion through melt extractions from this mantle wedge.

\section{Modeling of HFSE and LILE Source Depletion}

Depletions of HFSEs, especially $\mathrm{Nb}, \mathrm{Ta}$, and $\mathrm{Ti}$ relative to $\mathrm{N}$ MORB, have long been recognized as characteristic of arc-type magmas (e.g., Chayes and Velde, 1965; Gill, 1981), although no consensus has been reached as to the cause(s) of these geochemical signatures. The previous discussion suggests that such features are sourceinherited and develop as a consequence of multistage peridotitic source depletion, which, in principle, should be amenable to numerical modeling.

The results of two pairs of calculated fractional melting models are illustrated in Figure 21 (Models 1-4), based on spinel-pyroxene peridotite and amphibole peridotite model sources. Mineral phase abundances are from McKenzie and O'Nions (1991), and the assumed nonmodal phase melting ratios are listed on the figures. Initial melt fractions, melt increments, and amount of melt remaining in residue are all assumed to be 0.01 . Data are plotted as element ratios for each melt fraction, normalized to the starting composition. Element orders are the same as in previously presented spidergrams, except for Sr. The two sets of models differ in respect to the partition coefficient $\left(\mathrm{K}_{\mathrm{D}}\right)$ values used, especially for REEs (the choices of which clearly determine the outcome of the models). Models 1 and 2 utilize slightly modified $\mathrm{K}_{\mathrm{D}}$ values from basaltic andesites listed in Ewart and Hawkesworth (1987), except Ti (taken from McKenzie and O'Nions [1991] for all four models). In Models 3 and 4, $K_{D}$ values are slightly modified from Ewart and Hawkesworth (1987) and McKen- 

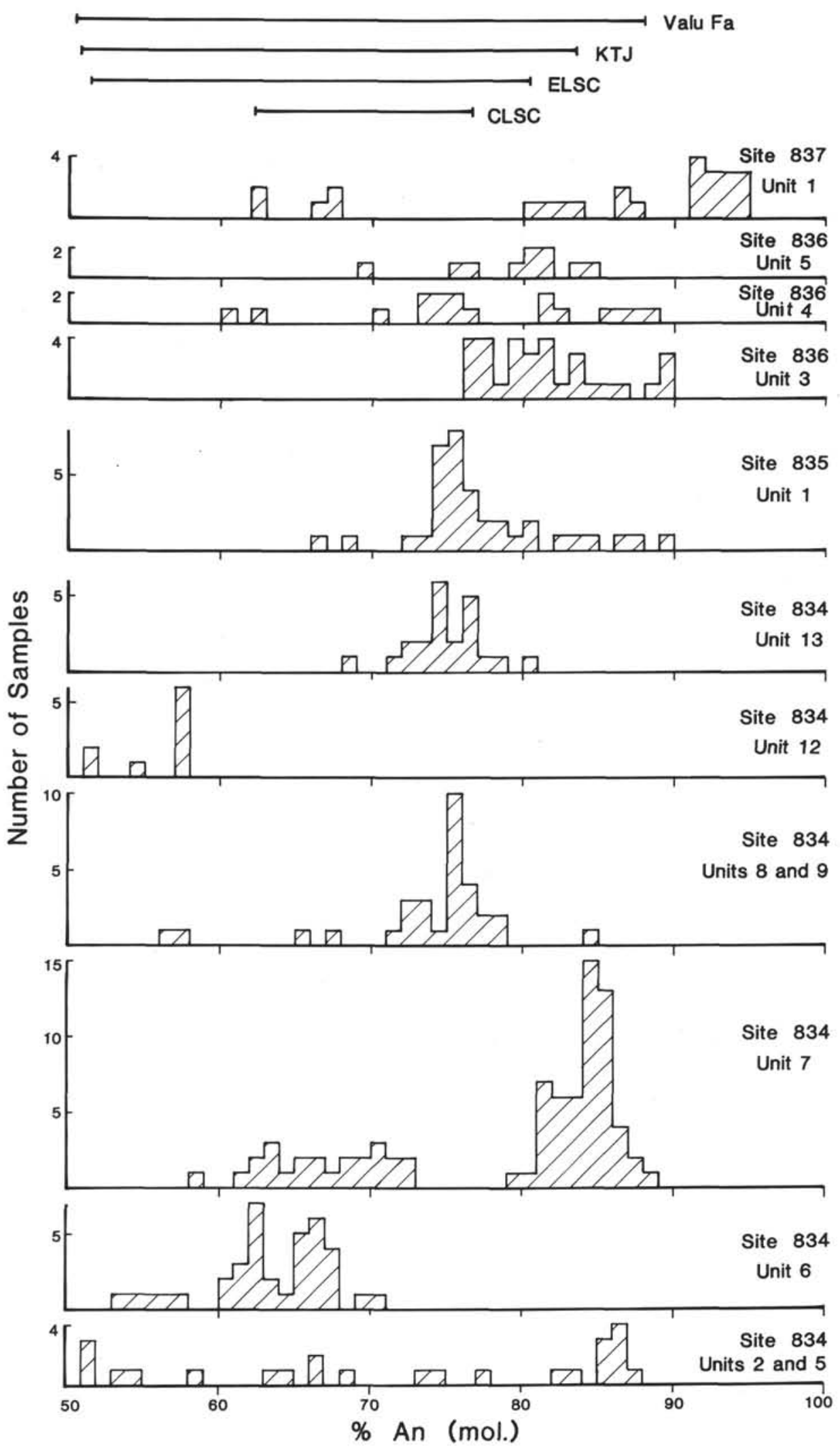

Figure 2. Compilation of plagioclase phenocryst and groundmass compositions, based on electron microprobe determinations, in lavas from Sites 834 to 837 . The published ranges of compositions of plagioclases from CLSC, ELSC, KTJ, and VF are shown for comparison. 
Table 5. Major element and new trace element analyses of modern Tonga-Kermadec lavas.

\begin{tabular}{|c|c|c|c|c|c|c|c|c|c|c|c|c|c|c|c|}
\hline $\begin{array}{l}\text { Island: } \\
\text { Sample: }\end{array}$ & & $\begin{array}{r}\text { Tong } \\
\text { Ta } \\
\mathrm{T}\end{array}$ & $\begin{array}{l}\text { Arc } \\
\text { hi } \\
6\end{array}$ & & $\begin{array}{l}\text { Tonga Are } \\
\text { Fonualei } \\
\text { F31 }\end{array}$ & To & $\begin{array}{l}\text { onga Arc } \\
\text { Late } \\
\text { L3 }\end{array}$ & $\mathrm{T}$ & $\begin{array}{l}\text { Tonga Arc } \\
\text { Metis } \\
11108\end{array}$ & $\begin{array}{r}\text { Tong: } \\
\mathrm{K} \\
10\end{array}$ & $\begin{array}{l}\text { Arc } \\
0 \\
\text { C }\end{array}$ & $\begin{array}{r}\text { Tong: } \\
\text { Tof } \\
\text { FN }\end{array}$ & $\begin{array}{l}\text { Arc } \\
\text { ua } \\
32\end{array}$ & $\begin{array}{l}\text { Tong: } \\
\text { Tof } \\
\text { FN }\end{array}$ & $\begin{array}{l}\text { Arc } \\
12 \\
12\end{array}$ \\
\hline Major ele & ts (wt\%) & & & & & & & & & & & & & & \\
\hline $\mathrm{SiO}_{2}$ & & & & & 60.57 & & 54.58 & & 64.25 & 53. & & 56. & & 56. & \\
\hline $\mathrm{TiO}_{2}$ & & & & & 0.66 & & 0.60 & & 0.39 & & 83 & 0. & & & 7 \\
\hline $\mathrm{Al}_{2} \mathrm{O}_{3}$ & & & & & 14.67 & & 15.86 & & 12.53 & 16. & & 14. & & 14. & \\
\hline $\mathrm{Fe}_{2} \mathrm{O}_{3}$ & & & 37 & & 4.17 & & 4.02 & & 1.36 & & 5 & & 25 & & 5 \\
\hline $\mathrm{FeO}^{\circ}$ & & & 90 & & 6.16 & & 6.85 & & 5.27 & & 72 & & 11 & & 1 \\
\hline $\mathrm{MnO}$ & & & 18 & & 0.21 & & 0.20 & & 0.12 & & 17 & & 19 & & 9 \\
\hline $\mathrm{MgO}$ & & & 97 & & 2.60 & & 4.94 & & 5.15 & & 83 & & 81 & & 1 \\
\hline $\mathrm{CaO}$ & & & & & 7.41 & & 10.26 & & 7.03 & 10. & & & 35 & & 35 \\
\hline $\mathrm{Na}_{2} \mathrm{O}$ & & & 6 & & 2.70 & & 1.69 & & 2.60 & & 31 & & 22 & & 2 \\
\hline $\mathrm{K}_{2} \mathrm{O}$ & & & 15 & & 0.72 & & 0.56 & & 0.91 & & 34 & & 88 & & 88 \\
\hline $\mathrm{P}_{2} \mathrm{O}_{5}$ & & & 94 & & 0.17 & & 0.09 & & 0.07 & & 14 & & 11 & & 1 \\
\hline Total & & & 80 & & 100.04 & & 99.65 & & 99.68 & 99. & & 99. & & 99. & \\
\hline LOI & & & 55 & & 0.46 & & 0.13 & & 0.91 & & 03 & & 15 & & 5 \\
\hline Trace ele & its (ppm): & & & & & & & & & & & & & & \\
\hline & a & b & c & a & b & a & b & a & b & a & b & a & b & a & b \\
\hline Cs & 0.04 & $<0.1$ & 0.106 & 0.18 & 0.35 & 0.13 & 0.20 & 0.79 & 0.70 & 0.12 & 0.15 & 0.17 & 0.30 & 0.17 & 0.30 \\
\hline $\mathrm{Rb}$ & 2 & & 2.3 & 11 & & 7 & & 14 & & 5.1 & & 7.6 & & 7.6 & \\
\hline $\mathrm{Sr}$ & 145 & & 108 & 305 & & 215 & & 140 & & 223 & & 207 & & 207 & \\
\hline $\mathrm{Zr}$ & 8 & & 13.8 & 37 & & 29 & & 46 & & 51.7 & & 42.6 & & 42.6 & \\
\hline $\mathrm{Nb}$ & 0.47 & & 0.55 & 1.39 & & 0.61 & & 0.48 & & 0.4 & & 0.34 & & 0.34 & \\
\hline $\mathrm{Y}$ & 6 & & 7.3 & 21 & & 17 & & 21 & & 18.4 & & 19.6 & & 19.6 & \\
\hline $\mathrm{U}$ & 0.08 & & 0.057 & 0.34 & & 0.19 & & 0.26 & & 0.16 & & 0.19 & & 0.19 & \\
\hline Th & 0,15 & & 0.106 & 0.32 & & 0.23 & & 0.30 & & 0.23 & & 0.2 & & 0.2 & \\
\hline $\mathrm{Pb}$ & 1.2 & & 1.24 & 2.63 & & 1.67 & & 4.44 & & 2.71 & & 2.63 & & 2.63 & \\
\hline $\mathrm{Ni}$ & 23 & & & & & 24 & & 53 & & 21 & & 10 & & 10 & \\
\hline $\mathrm{Cr}$ & 62 & 50 & & 6 & 4 & 43 & 38 & 313 & 250 & 39 & 34 & 15 & 11 & 15 & 11 \\
\hline V & 315 & & & 190 & & 320 & & 175 & & 338 & & 392 & & 392 & \\
\hline $\mathrm{Sc}$ & & 45 & & & 35 & & 48 & & 32 & 47 & 41 & 50 & 41 & 50 & 41 \\
\hline Co & 41 & 40 & & 24 & 23 & 39 & 37 & 28 & 27 & 40 & 38 & 36 & 35 & 36 & 35 \\
\hline $\mathrm{Cu}$ & 67 & & & 32 & & 160 & & 88 & & 77 & & 123 & & 123 & \\
\hline $\mathrm{Zn}$ & 72 & & & 113 & & 90 & & 58 & & 81 & & 107 & & 107 & \\
\hline $\mathrm{Ga}$ & 17.2 & & & 18.2 & & 16.8 & & 10.9 & & 15.8 & & 17.5 & & 17.5 & \\
\hline $\mathrm{Ba}$ & 47.9 & 55 & 45.5 & 186.1 & 180 & 136 & 110 & 362 & 330 & 137.4 & 120 & 173.4 & 170 & 173.4 & 170 \\
\hline $\mathrm{La}$ & 1.05 & 1.1 & 0.93 & 3.3 & 3.4 & 2.36 & 1.9 & 3.13 & 3.0 & 3.1 & 2.6 & 2.27 & 2.4 & 2.27 & 2.4 \\
\hline $\mathrm{Ce}$ & 2.28 & 2.3 & 2.53 & 7.64 & 8.1 & 5.95 & 5.0 & 7.23 & 7.0 & 8.48 & 7.2 & 5.93 & 6.2 & 5.93 & 6.2 \\
\hline $\operatorname{Pr}$ & 0.37 & & 0.385 & 1.27 & & 1.06 & & 1.19 & & 1.54 & & 1.05 & & 1.05 & \\
\hline Nd & 1.98 & [1.1] & 2.07 & 6.29 & 6.3 & 5.4 & 3.6 & 5.64 & 4.9 & 8.15 & 6.3 & 5.61 & 5.2 & 5.61 & 5.2 \\
\hline $\mathrm{Sm}$ & 0.75 & 0.6 & 0.75 & 2.09 & 1.9 & 1.84 & 1.3 & 1.88 & 1.5 & 2.73 & 2.1 & 2.09 & 1.9 & 2.09 & 1.9 \\
\hline $\mathrm{Eu}$ & 0.31 & 0.31 & 0.321 & 0.72 & 0.69 & 0.66 & 0.55 & 0.71 & 0.46 & 0.95 & 0.83 & 0.75 & 0.74 & 0.75 & 0.74 \\
\hline Gd & 1.12 & 1.1 & 1.05 & 2.67 & 2.3 & 2.36 & 1.8 & 2.29 & 2.0 & 3.47 & 2.8 & 2.97 & 2.7 & 2.97 & 2.7 \\
\hline $\mathrm{Tb}$ & 0.22 & {$[0.3]$} & & 0.49 & 0.5 & 0.43 & 0.4 & 0.42 & 0.4 & 0.62 & 0.6 & 0.57 & 0.5 & 0.57 & 0.5 \\
\hline Dy & 1.48 & & 1.43 & 3.05 & & 2.78 & & 2.64 & & 3.88 & & 3.66 & & 3.66 & \\
\hline Ho & 0.32 & 0.3 & 0.312 & 0.65 & 0.6 & 0.59 & 0.5 & 0.59 & 0.6 & 0.8 & 0.8 & 0.77 & 0.8 & 0.77 & 0.8 \\
\hline Er & 0.98 & & 0.946 & 1.95 & & 1.8 & & 1.70 & & 2.38 & & 2.34 & & 2.34 & \\
\hline $\mathrm{Tm}$ & 0.15 & & & 0.3 & & 0.27 & & 0.28 & & 0.36 & & 0.36 & & 0.36 & \\
\hline $\mathrm{Yb}$ & 1.03 & 1.1 & 0.95 & 2.09 & 2.1 & 1.9 & 1.7 & 1.87 & 1.9 & 2.45 & 2.2 & 2.42 & 2.3 & 2.42 & 2.3 \\
\hline $\mathrm{Lu}$ & 0.17 & 0.17 & & 0.35 & 0.33 & 0.32 & 0.27 & 0.29 & 0.30 & 0.4 & 0.34 & 0.39 & 0.36 & 0.39 & 0.36 \\
\hline $\mathrm{Ta}$ & 0.03 & & & 0.07 & & 0.09 & & 0.04 & & 0.04 & & 0.03 & & 0.03 & \\
\hline $\mathrm{Hf}$ & 0.51 & $<0.1$ & 0.344 & 1.18 & 0.7 & 1.07 & 0.5 & 1.38 & 0.9 & 1.65 & 0.9 & 1.25 & 0.8 & 1.25 & 0.8 \\
\hline $\mathrm{Sb}$ & & $<0.1$ & & & $<0.1$ & & $<0.1$ & & 0.75 & & $<0.1$ & & 0.10 & & 0.10 \\
\hline W & 0.05 & & 0.14 & 0.18 & & 0.91 & & 0.14 & & 0.1 & & 0.05 & & 0.05 & \\
\hline $\mathrm{Tl}$ & 0.15 & & & 0.44 & & 0.63 & & 1.21 & & 0.4 & & 0.44 & & 0.44 & \\
\hline $\mathrm{Be}$ & 0.23 & & & 0.19 & & 0.18 & & 0.22 & & 0.17 & & 0.21 & & 0.21 & \\
\hline $\mathrm{Li}$ & 4.5 & & & 7.4 & & 6.1 & & 11.1 & & 4.5 & & 4.7 & & 4.7 & \\
\hline
\end{tabular}

Note: See Table 2 for explanation of terms.

zie and O'Nions (1991), the latter authors using very low values for LREE for olivines and pyroxenes. The $K_{D}$ values are listed in Table 6. The progressive increments of fractional melts will, in principle, simulate the changing melt and source compositions during multistage magma extraction (initially taken as N-MORB).

Results indicate that both spinel-pyroxene peridotite models predict preferential $\mathrm{Nb}$-Th-Ti depletions at melt fractions exceeding 0.10 (Models 1 and 3), together with even stronger LILE depletions (emphasizing the necessity of subduction-related replenishment of these elements in such models for the arc magmas; cf. Figs. 16-19). The major difference between Models 1 and 3 is in the extent of LREE depletion, which is extreme in Model 3. Such extreme LREE depletions are not observed in arc magmas, suggesting that, in the context of the present models, either the very low $\mathrm{K}_{\mathrm{D}}$ values for the LREEs are inappropriate or the LREEs are also selectively replenished with LILEs from the subduction source. The amphibole peridotite fractional melting models (Models 2 and 4) do not predict the same degree of $\mathrm{Nb}$ depletion, although they still produce limited $\mathrm{Ti}$ depletion, as a result of the effective buffering of $\mathrm{Nb}$, and to a lesser extent $\mathrm{Ti}$, by amphibole. The LILEs exhibit strong preferential depletions, as in Models 1 and 3.

Thus, the models point to the plausibility that multistage magma extraction from spinel-pyroxene peridotite (in which amphibole is no more than a minor phase) has the capability of producing melts with progressive selective depletion in $\mathrm{Nb}$ and $\mathrm{Ti}$; other HFSEs will also be depleted but at a less rapid rate. The obvious implication, which is considered relevant to the Lau-Tonga-Kermadec arc-backarc system, is that the further the multistage melt extraction processes have advanced, the more extreme are the relative HFSE depletions.

\section{Geochemical Evidence for Variable Source Depletion}

Ewart and Hawkesworth (1987) utilized parameters such as $\mathrm{TiO}_{2} /$ $\mathrm{CaO}$ and $\mathrm{TiO}_{2} / \mathrm{Al}_{2} \mathrm{O}_{3}$ as measures of source depletion, and the ratios $\mathrm{Zr} / \mathrm{Ba}$ and $\mathrm{Sr} / \mathrm{Nd}$ as convenient trace element ratios with which to illustrate the balance between "immobile" element depletion and su- 
Table 5 (continued).

\begin{tabular}{|c|c|c|c|c|c|c|c|c|c|c|c|c|}
\hline $\begin{array}{l}\text { Island: } \\
\text { Sample: }\end{array}$ & $\begin{array}{r}\text { Tor } \\
\text { Hung } \\
1\end{array}$ & $\begin{array}{l}\text { ara Arc } \\
\text { a Ha'apai } \\
\mathrm{HH} 1\end{array}$ & & $\begin{array}{l}\text { Tonga } \\
\text { iua fo'ou } \\
\text { N107 }\end{array}$ & $\begin{array}{r}\text { Kermac } \\
\text { Raol } \\
710\end{array}$ & $\begin{array}{l}\text { decs } \\
\text { ul } \\
1\end{array}$ & $\begin{array}{r}\text { Kerm } \\
\mathrm{Ra} \\
23\end{array}$ & $\begin{array}{l}\text { adecs } \\
\text { oul } \\
76\end{array}$ & $\begin{array}{r}\text { Kerm } \\
\text { Mac } \\
10\end{array}$ & $\begin{array}{l}\text { adecs } \\
\text { uley } \\
15\end{array}$ & $\begin{array}{r}\text { Kerm } \\
\text { L'Esp } \\
14\end{array}$ & $\begin{array}{l}\text { decs } \\
\text { rance } \\
37\end{array}$ \\
\hline \multicolumn{13}{|c|}{ Major elements (wt \%): } \\
\hline $\mathrm{SiO}_{2}$ & \multicolumn{2}{|c|}{54.56} & & 49.32 & \multicolumn{2}{|c|}{50.98} & \multicolumn{2}{|c|}{53.90} & \multicolumn{2}{|c|}{49.04} & \multicolumn{2}{|c|}{51.87} \\
\hline $\mathrm{TiO}_{2}^{2}$ & \multicolumn{2}{|r|}{0.49} & & 1.78 & \multicolumn{2}{|c|}{0.85} & \multicolumn{2}{|c|}{0.64} & \multicolumn{2}{|c|}{0.55} & \multicolumn{2}{|c|}{1.01} \\
\hline $\mathrm{Al}_{2} \mathrm{O}_{3}$ & \multicolumn{2}{|c|}{18.56} & & 15.73 & \multicolumn{2}{|c|}{18.79} & \multicolumn{2}{|c|}{14.00} & \multicolumn{2}{|c|}{17.41} & & \\
\hline $\mathrm{Fe}_{2} \mathrm{O}_{3}$ & & 2.08 & & 4.97 & 2.6 & & & 18 & & 17 & & 59 \\
\hline $\mathrm{FeO}$ & & 6.74 & & 6.73 & 7.6 & & & 78 & & 65 & & 39 \\
\hline $\mathrm{MnO}$ & & 0.16 & & 0.21 & 0.1 & & & 18 & & 17 & & 24 \\
\hline $\mathrm{MgO}$ & & 4.17 & & 6.08 & 4.19 & & & 22 & & 31 & & 99 \\
\hline $\mathrm{CaO}$ & & 1.33 & & 11.18 & 12.2 & & & 31 & & & & 31 \\
\hline $\mathrm{Na}_{2} \mathrm{O}$ & & 1.78 & & 3.49 & 2.0 & & & 05 & & 32 & & 34 \\
\hline $\mathrm{K}_{2} \mathrm{O}$ & & 0.24 & & 0.24 & 0.2 & & & 29 & & 14 & & 30 \\
\hline $\mathrm{P}_{2} \mathrm{O}_{5}$ & & 0.06 & & 0.15 & 0.0 & & & 07 & & 01 & & 6 \\
\hline Total & & 00.17 & & 99.88 & 99.9 & & & 71 & & & & \\
\hline LOI & & 0.22 & & 0.22 & 1.0 & & & 09 & & 47 & & 14 \\
\hline Trace eleme & & & & & & & & & & & & \\
\hline & a & b & a & b & a & b & a & b & a & b & a & b \\
\hline Cs & 0.13 & 0.15 & 0.04 & $<0.1$ & 0.11 & 0.30 & 0.11 & 0.20 & 0.05 & 0.10 & 0.17 & 0.45 \\
\hline $\mathrm{Rb}$ & 4 & & 3.4 & & 4.5 & & 4.3 & & 1.6 & & 6.70 & \\
\hline $\mathrm{Sr}$ & 185 & & 170 & & 200 & & 153 & & 185 & & 210 & \\
\hline $\mathrm{Zr}$ & 24 & & 120 & & 32 & & 44.9 & & 15 & & 45 & \\
\hline $\mathrm{Nb}$ & 0.52 & & 4.51 & & 0.4 & & 0.46 & & 0.22 & & 0.41 & \\
\hline $\mathrm{Y}$ & 16 & & 32 & & 21 & & 16.1 & & 13 & & 20 & \\
\hline $\mathrm{U}$ & 0.14 & & 0.11 & & 0.12 & & 0.14 & & 0.05 & & 0.19 & \\
\hline Th & 0.14 & & 0.37 & & 0.31 & & 0.31 & & 0.13 & & 0.51 & \\
\hline $\mathrm{Pb}$ & 1.09 & & 1.27 & & 1.96 & & 1.72 & & 1.58 & & 2.98 & \\
\hline $\mathrm{Ni}$ & 26 & & 38 & & 15 & & & & 49 & & 15 & \\
\hline $\mathrm{Cr}$ & 54 & 42 & 215 & 200 & 36 & 24 & 196 & 170 & 150 & 50 & 23 & 12 \\
\hline V & 260 & & 265 & & 360 & & 301 & & 280 & & 360 & \\
\hline $\mathrm{Sc}$ & & 41 & 50 & 50 & & 39 & 47 & 45 & & 48 & & 42 \\
\hline $\mathrm{Co}$ & 30 & 29 & 46 & 44 & 40 & 39 & 44 & 43 & 45 & 43 & 42 & 40 \\
\hline $\mathrm{Cu}$ & 130 & & 73 & & 87 & & & & 84 & & 42 & \\
\hline $\mathrm{Zn}$ & 75 & & 83 & & 83 & & & & 60 & & 99 & \\
\hline $\mathrm{Ga}$ & 18.1 & & 20.6 & & 21.3 & & 16.2 & & 15.3 & & 21.8 & \\
\hline $\mathrm{Ba}$ & 141 & 110 & 45.8 & 60 & 91.8 & 80 & 96.5 & 100 & 50.8 & 50 & 141.40 & 30 \\
\hline $\mathrm{La}$ & 1.8 & 1.4 & 5.74 & 5.9 & 2.52 & 2.6 & 2.71 & 2.7 & 1.23 & 1.2 & 3.12 & 3.1 \\
\hline $\mathrm{Ce}$ & 4.59 & 3.1 & 15.5 & 16.6 & 6.40 & 6.8 & 7.01 & 7.5 & 3.28 & 3.2 & 7.87 & 8.1 \\
\hline $\mathrm{Pr}$ & 0.82 & & 2.61 & & 1.11 & & 1.16 & & 0.57 & & 1.33 & \\
\hline $\mathrm{Nd}$ & 4.34 & 2.6 & 13.6 & 13.4 & 5.84 & 5.4 & 5.84 & 5.5 & 3.14 & 2.4 & 6.79 & 6.4 \\
\hline $\mathrm{Sm}$ & 1.56 & 1.1 & 4.61 & 4.1 & 2.030 & 1.9 & 1.94 & 1.8 & 1.15 & 1.0 & 2.31 & 2.0 \\
\hline $\mathrm{Eu}$ & 0.58 & 0.46 & 1.61 & 1.66 & 0.730 & 0.78 & 0.66 & 0.69 & 0.47 & 0.47 & 0.90 & 0.91 \\
\hline Gd & 2.16 & 1.7 & 6.42 & 5.8 & 2.67 & 2.6 & 2.53 & 2.4 & 1.55 & 1.5 & & 2.9 \\
\hline $\mathrm{Tb}$ & 0.4 & 0.3 & 1.2 & 1.1 & 0.51 & 0.5 & 0.47 & 0.6 & 0.29 & {$[0.4]$} & 3.11 & 0.6 \\
\hline Dy & 2.66 & & 7.36 & & 3.17 & & 2.96 & & 1.82 & & 0.59 & \\
\hline Ho & 0.58 & 0.5 & 1.52 & 1.5 & 0.67 & 0.7 & 0.62 & 0.6 & 0.37 & 0.4 & 3.76 & 0.6 \\
\hline $\mathrm{Er}$ & 1.74 & & 4.44 & & 1.99 & & 1.84 & & 1.09 & & 2.31 & \\
\hline $\mathrm{Tm}$ & 0.27 & & 0.67 & & 0.30 & & 0.29 & & 0.16 & & 0.35 & \\
\hline $\mathrm{Yb}$ & 1.88 & 1.5 & 4.31 & 4.3 & 2.05 & 2.1 & 1.95 & 1.9 & 1.06 & 1.2 & 2.42 & 2.2 \\
\hline $\mathrm{Lu}$ & 0.31 & 0.26 & 0.68 & 0.62 & 0.34 & 0.32 & 0.32 & 0.30 & 0.17 & 0.19 & 0.39 & 0.35 \\
\hline $\mathrm{Ta}$ & 0.03 & & 0.32 & & 0.05 & & 0.04 & & 0.02 & & 0.04 & \\
\hline $\mathrm{Hf}$ & 0.91 & 0.3 & 3.34 & 2.8 & 1.19 & 0.5 & 1.27 & 0.8 & 0.57 & & 1.28 & 0.8 \\
\hline $\mathrm{Sb}$ & & 0.15 & & $<0.1$ & & 0.10 & & & & 0.10 & & 0.10 \\
\hline W & 0.06 & & 0.08 & & 0.05 & & 0.05 & & 0.03 & & 0.24 & \\
\hline $\mathrm{Tl}$ & 0.44 & & 0.19 & & 0.26 & & 0.26 & & 0.20 & & 0.42 & \\
\hline $\mathrm{Be}$ & 0.23 & & 0.23 & & 0.20 & & 0.19 & & 0.22 & & 0.19 & \\
\hline $\mathrm{Li}$ & 4.9 & & 6.0 & & 4.7 & & 5.2 & & 4.7 & & 4.1 & \\
\hline
\end{tabular}

perimposed LILE enrichment. Plots of $\mathrm{TiO}_{2} / \mathrm{CaO}$ vs. $\mathrm{Zr} / \mathrm{Ba}$ (Fig. 22) and $\mathrm{Sr} / \mathrm{Nd}$ (Fig. 23) present data from all major subprovinces of the region, again however, only including rock data for which $\mathrm{MgO}>$ $4 \%$. For reference, Figure 22 also shows the ranges of $\mathrm{TiO}_{2} / \mathrm{CaO}$ of the experimental equilibrium melts from model Hawaiian pyrolite (undepleted), but rather high $\mathrm{TiO}_{2}$ ) and Tinaquillo lherzolite (depleted) sources (Falloon et al., 1988), which clearly confirm the low $\mathrm{TiO}_{2} / \mathrm{CaO}$ ratios of melts to be expected from relatively refractory peridotitic sources.

Considering first the Leg 135 site data in Figure 22, there is a clear trend of decreasing $\mathrm{TiO}_{2} / \mathrm{CaO}$ and $\mathrm{Zr} / \mathrm{Ba}$ ratios going from Site 834 , through Sites 835 and 836 , to Site 839 . This trend is matched by the data fields for the modern Lau spreading centers in which there is a parallel trend of decreasing ratios from CLSC to ELSC and KTJ to Valu Fa. These trends are here broadly correlated with both increasing source depletion, and increasing LILE source "metasomatism" toward Site 839 and Valu Fa. Reference to the fields for the modern arc volcanoes (shown, in part, in the inset to Fig. 22) and the boninites indicate a clear continuation of these "depletion" trends through Tonga to the boninites. This plot, in fact, suggests a progressive evolution of the Tongan lavas, with those of 'Ata and Kao defining the more "fertile" end of the data array. The Kermadec volcanoes exhibit more variable trends, consistent with their greater variability of bulk chemistry; the lavas of the southern Kermadec volcano of L'Esperance are again distinct from those of the northern Kermadec arc. Finally, attention is drawn to the Lau Ridge volcanics, namely the Lau and Korobasaga Volcanic Groups. Although the latter are more pronounced in their arc-like geochemistry, as noted by Cole et al. (1990), neither group exhibits the degree of depletion implied by the data for Tonga, most of the Kermadec lavas, and the boninites.

Figure 23, the complementary $\mathrm{Sr} / \mathrm{Nd}$ plot, reveals a similar pattern of compositional changes. For example, the change toward "arc-like" chemistry is apparent in the Site 839 and Valu Fa data compared to the Sites 834, 835, the CLSC, and ELSC. Similarly, the arc lavas and boninites exhibit overlapping compositional characteristics, the main difference being that the boninites do not extend to the same high $\mathrm{Sr} / \mathrm{Nd}$ ratios as the northern Tongan lavas.

As a further illustration of the inferred systematically changing source depletion characteristics, Figure 24 illustrates the changing ratios of $\mathrm{Zr} / \mathrm{Sm}$. According to the data of Sun and McDonough (1989), 


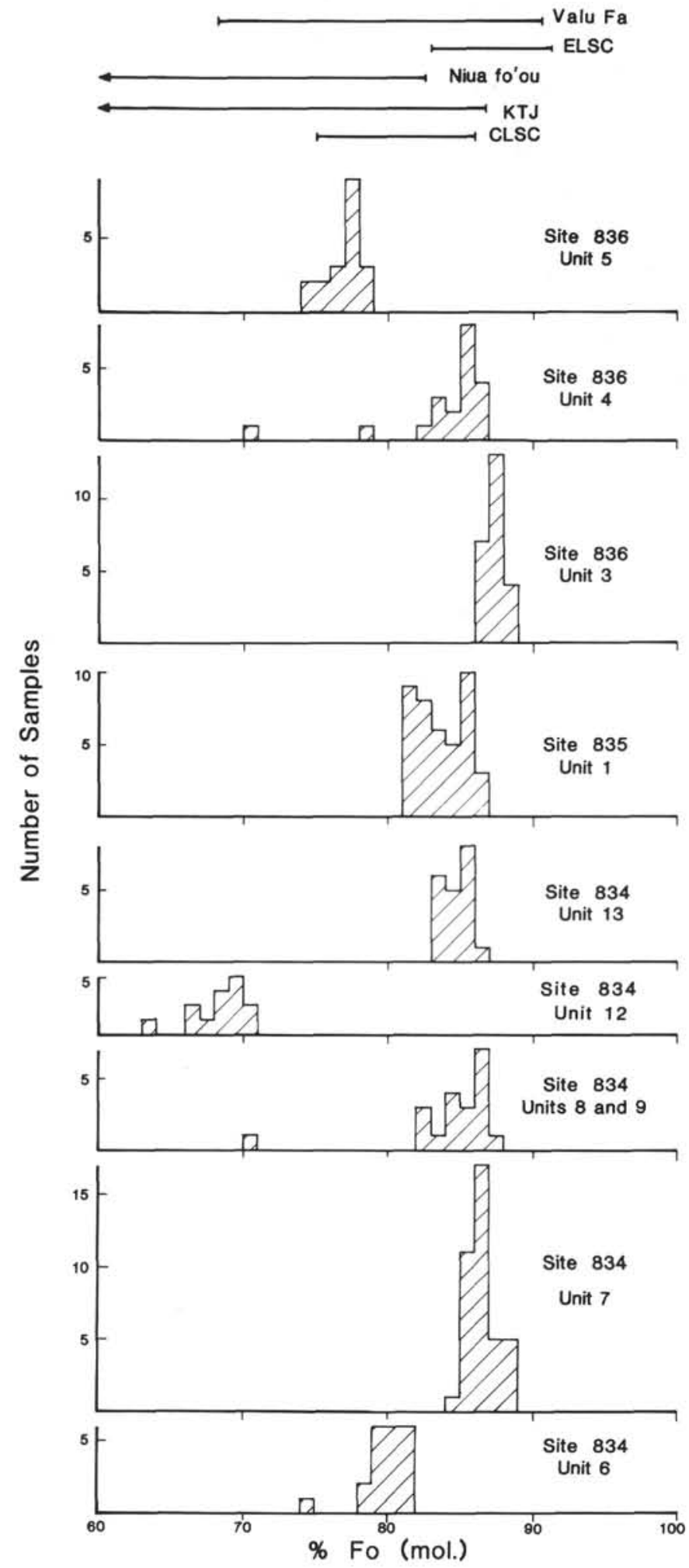

Figure 3. Compilation of olivine phenocryst and microphenocryst compositions, based on electron microprobe determinations, in lavas from Sites 834 to 836. The published ranges of compositions of olivines from CLSC, ELSC, KTJ, VF, and Niuafo'ou are also shown for comparison. these two elements behave coherently in N-MORB, enriched midocean-ridge basalts (E-MORB), and ocean-island basalt magmas (OIB; with ${ }^{87} \mathrm{Sr} /{ }^{86} \mathrm{Sr}$ of approximately 0.7035 ), the averaged $\mathrm{Zr} / \mathrm{Sm}$ ratios lying close to 28 . The Lau-Tonga-Kermadec data indicate a generally decreasing $\mathrm{Zr} / \mathrm{Sm}$ ratio that drops to between 10 and 20 with decreasing $\mathrm{Zr} / \mathrm{Ba}$. It is important to note that fractional crystallization has only minor effects on the $\mathrm{Zr} / \mathrm{Sm}$ ratios, as shown by the small change in the matrix Sample 135-839B-25R-1, 27-32 cm, of 17.4 compared with the whole-rock value of 19.2 .

The experimental data of Falloon et al. (1988) provide important constraints on the bulk compositions of liquids produced by equilibrium partial melting of model peridotite sources that are undepleted (Hawaiian pyrolite) and depleted (Tinaquillo lherzolite). A major conclusion is the confirmation of the relatively silica-saturated compositions of the melts derived from the more refractory sources. Figures 9-11 compare the $\mathrm{CaO}, \mathrm{Na}_{2} \mathrm{O}$, and $\mathrm{TiO}_{2}$ abundances of these experimental liquids; the data clearly show the lower $\mathrm{Na}_{2} \mathrm{O}, \mathrm{TiO}_{2}$, and higher $\mathrm{CaO}$ contents of the Tinaquillo equilibrium melts. These trends, particularly $\mathrm{Na}_{2} \mathrm{O}$ and $\mathrm{TiO}_{2}$, are entirely consistent with the directions of "depletion" shown by the trace element data. The survey of phenocryst mineralogical compositions, previously presented, are also consistent with mineralogically heterogeneous sources, due to varying prior melt extraction processes. For example, amongst the Site 839 lavas, the highly magnesian olivines (Unit 3) and calcic plagioclases (Unit 9) indicate relatively refractory sources, as do the Cr-rich spinels in Units 1 and 3 (Allan, this volume).

In Figures 6 and 7, the normative compositions of the experimental liquids are shown projected (from plagioclase) into the silica-olivineclinopyroxene, and from clinopyroxene into the olivine-plagioclasesilica systems. The data are approximately contoured according to the residual phases in equilibrium with these liquids. These data suggest that the less silica-saturated to silica-undersaturated compositions as found, for example, in Sites 834, 836, and the CLSC and KTJ, are more consistent with less depleted, MORB-like sources. The compositional fields, however, for the northern Tonga boninites, and the Site 839 data, imply refractory sources, possibly in equilibrium with a near-harzburgitic mineralogy (e.g., Duncan and Green, 1987). It is further possible that the small shifts in the compositional fields toward olivine, as seen for example in the CLSC, ELSC, ILSC, and Valu Fa data, may also reflect changing source characteristics toward slightly more refractory chemistries.

In view of the previous interpretations of the existence of magma source heterogeneities within the coupled Lau-Tonga mantle, it is relevant to view these geographically. Thus, in Figure 25, the ranges of $\mathrm{Zr} / \mathrm{Ba}$ ratios observed in the various volcanic zones and centers are plotted, including the Leg 135 drill sites (the ratios listed in Table 7). As previously discussed, $\mathrm{Zr} / \mathrm{Ba}$ ratios are inferred to reflect melt source characteristics, are only slightly affected by moderate degrees of fractional crystallization, and are readily measured by XRF techniques (thus providing a good data set); these ratios may, however, be modified by magma mixing and assimilation-fractional crystallization processes (e.g., Hergt and Nilsson, this volume).

Figure 25 shows that within the Lau Basin, $\mathrm{Zr} / \mathrm{Ba}$ ranges are greater, and generally higher than observed in the arc lavas of the Tonga and Lau ridges, but that a southerly decrease of $\mathrm{Zr} / \mathrm{Ba}$ occurs, most notably at Site 839 and Valu Fa. On the Lau Ridge, the LVG possess ratios significantly higher than either the associated KVG or the modern Tofua Arc lavas. Along the Tofua Arc, there is an overall trend of northerly decreasing $\mathrm{Zr} / \mathrm{Ba}$ ratios (especially noting the lower ratio limits), with the exception of the youthful volcano of Kao in the central Tofua Arc. Comparing the arc volcanos of the Lau and Tonga ridges, the LVG magma sources appear less depleted than those beneath the Tofua Arc, although the younger KVG of the Lau Ridge exhibit similar $\mathrm{Zr} / \mathrm{Ba}$ ratios to those of Tonga. It has already been shown, however, that both arc-related volcanic groups from the Lau Ridge have much less depleted HFSE abundances than occur in the Tofua Arc magmas (cf. Fig. 19). It is thus thought that magma sources beneath the Lau 

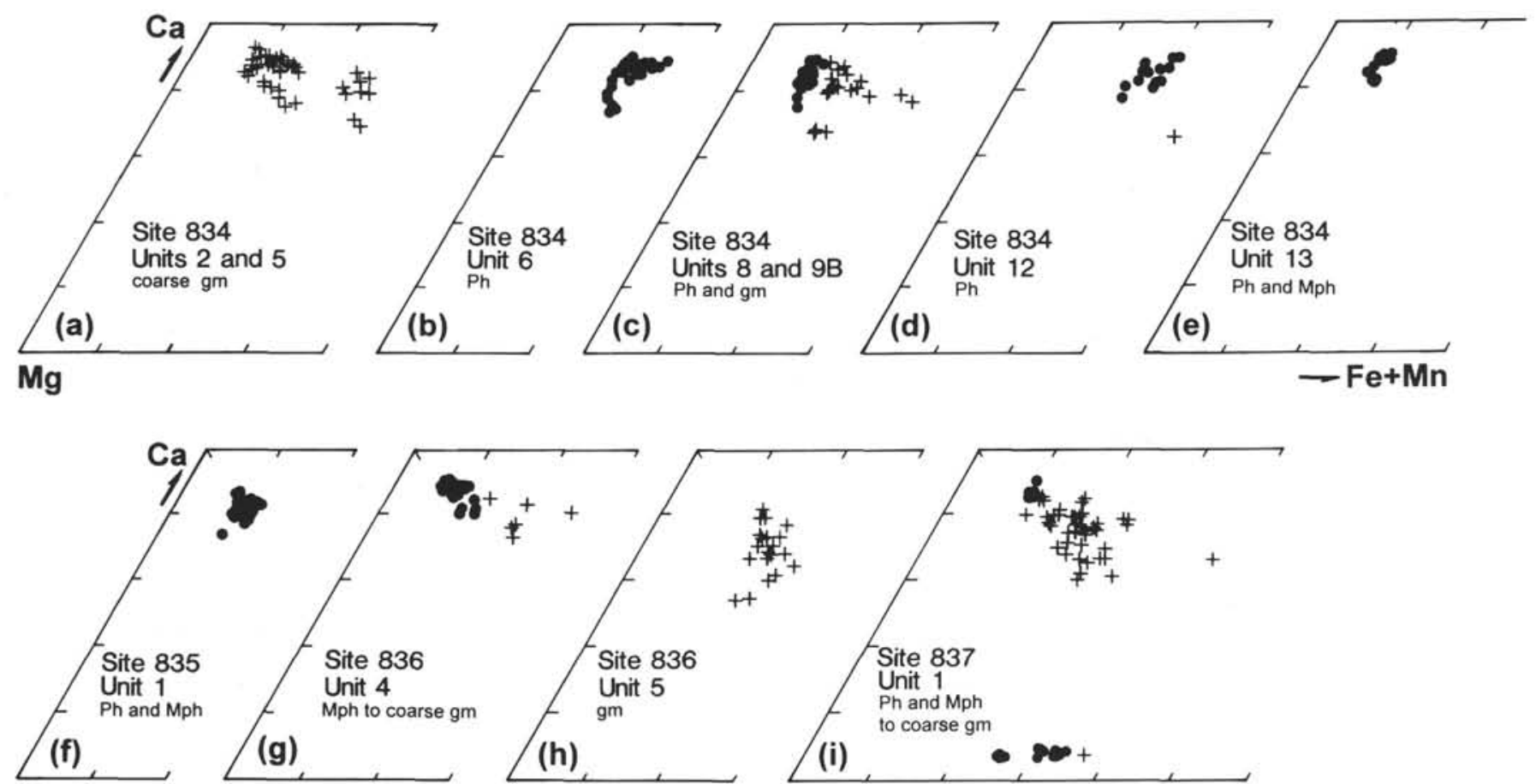

$\mathrm{Mg}$

$-\mathrm{Fe}+\mathrm{Mn}$

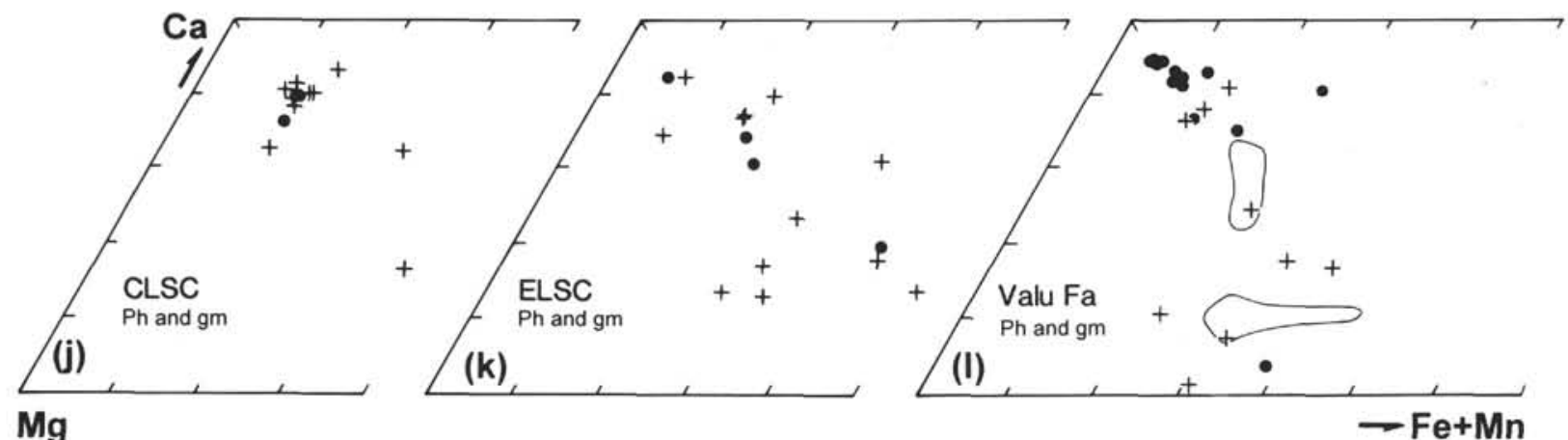

Figure 4. Compilation of pyroxene compositions, based on electron microprobe determinations, in lavas from Sites 834 to 837 (Figs. 4A-4I). Data plotted in terms of $\mathrm{Ca}, \mathrm{Mg}$, and $\mathrm{Fe}+\mathrm{Mn}$ (atomic \%). Also shown (Figs. 4J-4L) are comparative published data from CLSC, ELSC, and VF. Phenocryst/microphenocryst (Ph) data are plotted as solid circles, whereas groundmass (gm) phases are plotted as crosses.

Ridge were less refractory than currently exist beneath the modern Tonga Ridge.

The overall pattern emerging is that within the Lau Basin, the ELSC-Valu Fa propagator is becoming strongly "arc-like" geochemically as it approaches the modern Tofua Arc, with the Leg 135 sites also becoming more "arc-like" southeastward across the older, western segment of Lau Basin crust, presumably also reflecting increasing proximity toward the arc environment before the renewed opening of the central eastern Lau Basin by the ELSC propagator system. A compilation of the ranges of significant element ratios from the various subregions of Lau-Tonga illustrating the regional and temporal changes of geochemistry, is presented in Table 7.

\section{A POSSIBLE MODEL}

Parson and Hawkins (this volume) have developed a two-stage model of Lau Basin evolution, the following summarized from their paper: The active Lau-Fiji-Tonga proto-arc underwent protracted extension commencing sometime after $10 \mathrm{Ma}$, resulting in opening of a largely amagmatic basin floor characterized by irregular horstand-graben topography, through the period before 5.5 Ma. At approximately $5.5 \mathrm{Ma}$, true backarc spreading initiated in the north central Lau Basin and propagated southward from the Peggy Ridge, forming the ELSC, the southern limit of which is now the Valu Fa Ridge. Axial spreading results in fan-shaped opening of the eastern portion of the Lau Basin. A later southward moving propagator, the CLSC, commenced from the southeastern limit of the Peggy Ridge between 1.2 and 1.5 Ma. Isotopic data by Hergt and Hawkesworth (this volume) has shown that an influx of asthenosphere with Indian Ocean mantle isotopic affinities accompanied the younger phase of true, backarc spreading, displacing older asthenosphere with Pacific Ocean mantle isotopic affinities beneath the backarc region. As previously noted, the isotopic data further indicate that mixing between the two asthenospheric end-members has occurred. The implications, therefore, point to dominantly "Pacific" mantle beneath the Lau Ridge, the western part of the Lau Basin, and the Tonga (Kermadec) Ridge, with 


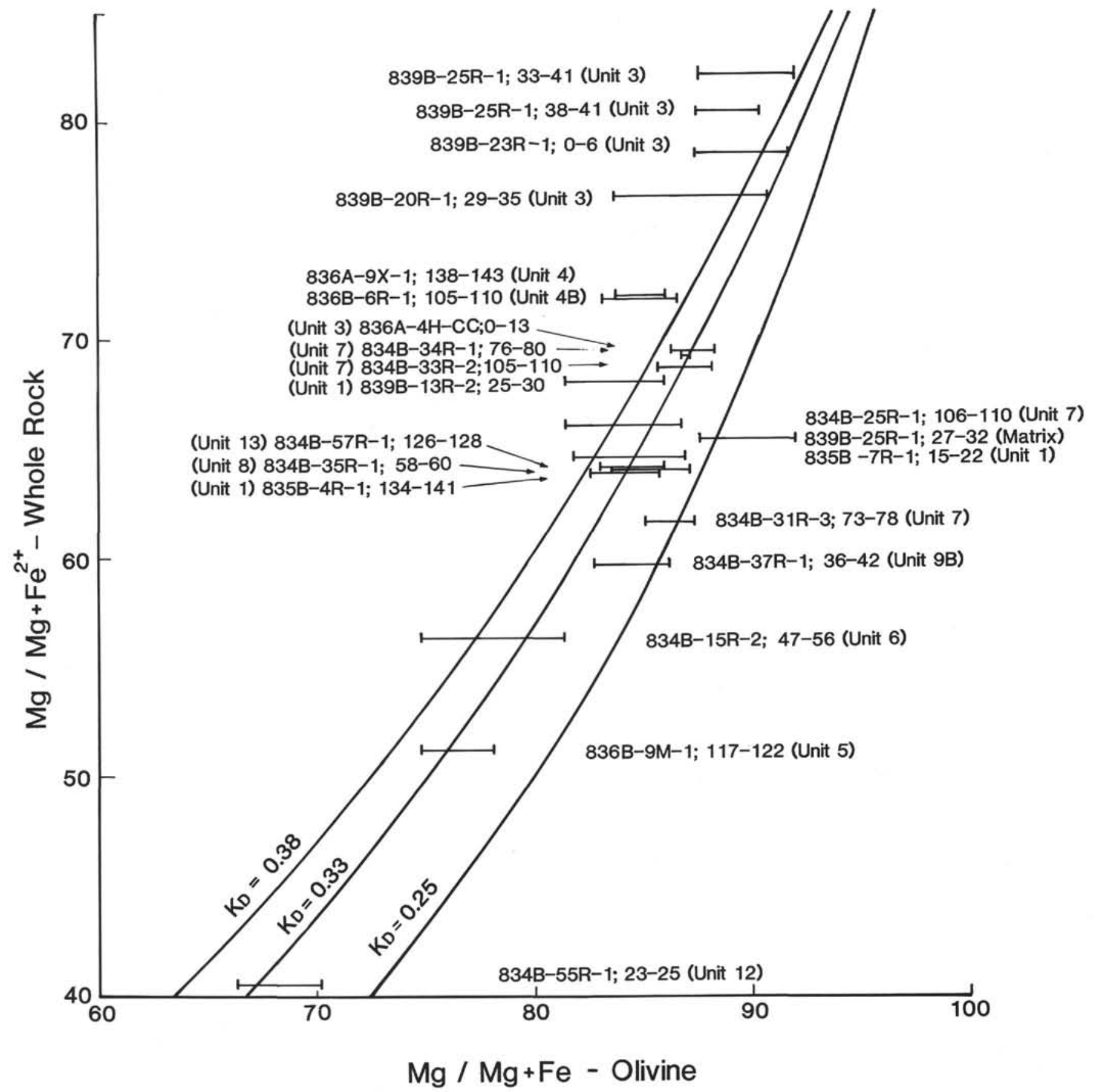

Figure 5. Ranges of olivine compositions (microprobe determinations; expressed as atomic\% $\mathrm{Mg} /\left(\mathrm{Mg}+\mathrm{Fe}_{t}\right.$ ) in lava samples from Sites $834,835,836$, and 839 , compared to their bulk-rock (and one-matrix) compositions, expressed as $\mathrm{Mg}$ values (atomic $\% \mathrm{Mg} /\left(\mathrm{Mg}+\mathrm{Fe}^{2+}\right.$ ), assuming $\mathrm{Fe}_{2} \mathrm{O}_{3} / \mathrm{FeO}^{2}=0.2$ ). Three sets of $\mathrm{Fe}-\mathrm{Mg}$ partition coefficient curves are shown.

"Indian" mantle beneath the wedge-shaped eastern portion of the Lau Basin, at least south of the Peggy Ridge. The systematics north of the Peggy Ridge are still unclear.

The above interpretation also clearly implies that the western "horst-and-graben" segment of the Lau Basin, before propagator activity, lay adjacent to the Tonga Ridge and arc, and thus significantly closer to the subduction zone. This is believed to be the reason why the lavas from Sites 835 and 837-839 exhibit such strong, although variable, arc-like geochemical signatures. In fact, it is proposed that Site 839 may actually represent an abandoned arc volcanic construct belonging to an early phase of the Tongan arc volcanism, now stranded within the Lau Basin by the subsequent opening up the eastern part of the Lau Basin by propagator activity (see Ewart, Hergt and Hawkins, this volume, for further discussion of Site 839).

Arc-related volcanism on the Lau Ridge occurred continuously from 14 to $5.4 \mathrm{Ma}$ (Lau Volcanic Group), and 4.4 to $2.4 \mathrm{Ma}$ (Korobasaga Volcanic Group), clearly overlapping the earlier phase of Lau Basin extension (Cole et al., 1985, 1990). However, data compiled by Jarrard (1986) indicate that the age at which the tip of the Tongan slab began subduction was approximately $9.6-10 \mathrm{Ma}$, suggesting that the present Tongan (and Kermadec) subduction zone was not associated with at least the earliest stages of Lau Ridge arc volcanism. 

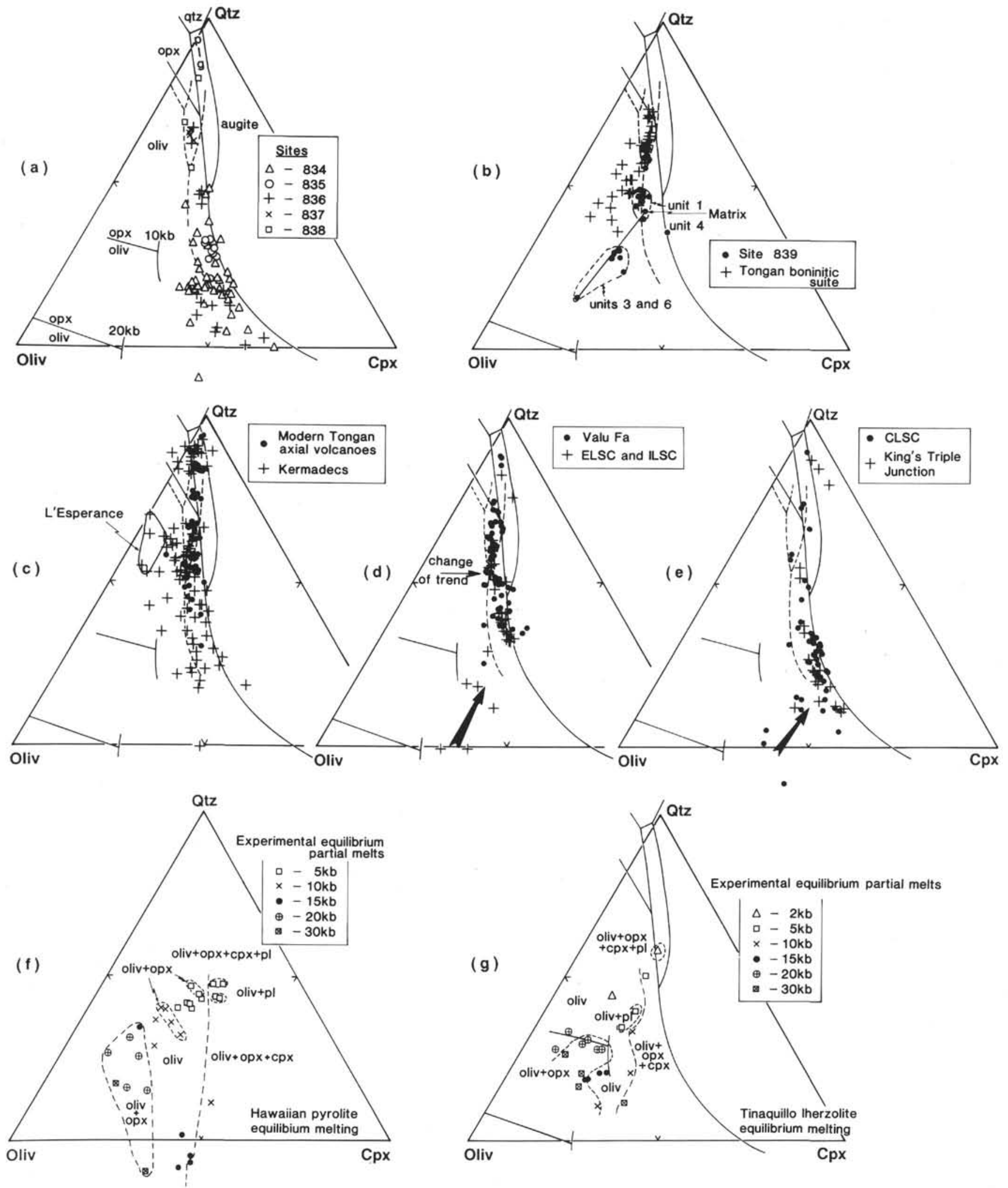

Figure 6. Compositions of lava from Sites 834 to 839 , the Lau Basin spreading centers, the modern Tongan and Kermadec axial volcanoes, and the northern Tongan boninites, plotted in terms of olivine (Oliv), silica (Qtz), and clinopyroxene ( $\mathrm{Cpx}$ ) (projected from plagioclase). The solid lines are the 1-atm. cotectics and reaction curves (after Grove and Bryan, 1983), as are the projected 10- and 20-Kbar cotectics. The dashed curves are inferred cotectics and reaction curves, at $\mathrm{P}_{\mathrm{H}_{2} \mathrm{O}}=1000$ bars, after Grove et al. (1982). Projection scheme calculation after Grove et al. (1982). Data sources for this, and following figures, listed in text. In Figures $6 \mathrm{~F}$ and 6G, the experimental equilibrium liquid compositions, at various pressures, are plotted after Falloon et al. (1988); the residual mineral assemblages in equilibrium with these liquids are approximately contoured. 

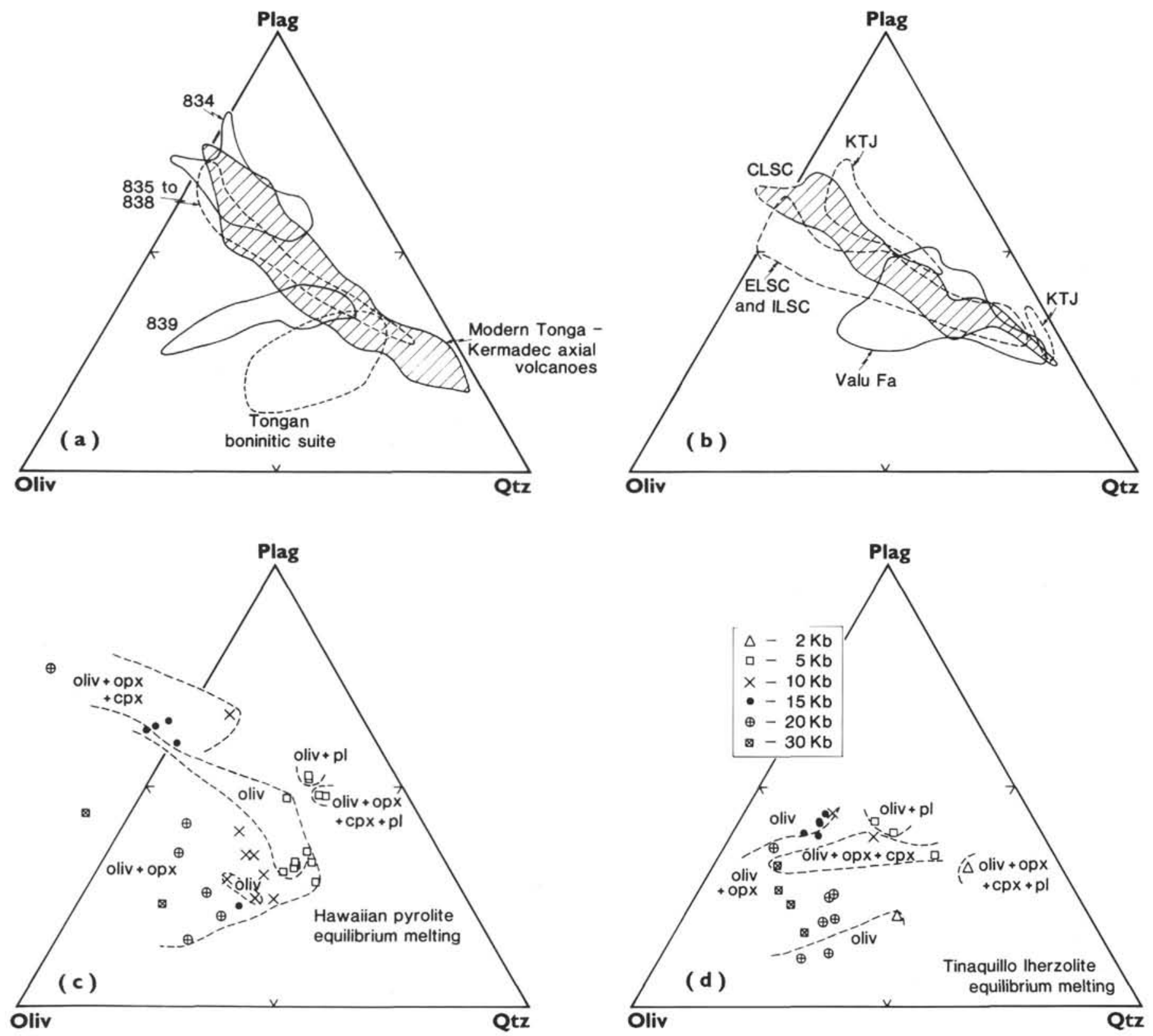

Figure 7. Compositions of lavas from Sites 834 to 839, the Lau Basin spreading centers, the modern Tonga-Kermadec axial volcanoes, and the northern Tongan boninites plotted in terms of olivine (Oliv), silica (Qtz), and plagioclase (Plag), projected from clinopyroxene. Projection scheme after Grove et al. (1982). In Figures 7C and 7D, the experimental liquid compositions, at various pressures, are plotted after Falloon et al. (1988), and the residual mineral assemblages that are in equilibrium with these liquids are approximately contoured.

The primary event, therefore, which is thought to have caused initiation of Lau-Tonga extension, and subsequent backarc spreading, is an abrupt jump in the position of the subduction zone. The reason for such a jump would plausibly be extended slab rollback. If correct, such a jump is inferred to have caused a change in mantle streamline flow resulting in a tensional regime sufficient to initiate rifting of the formerly continuous Lau-Tonga ridge system (see Fig. 26).

Analyses of deep seismic data for the Tonga-Kermadec region by Giardini and Woodhouse (1984) show a zone of very contorted seismicity extending to $650 \mathrm{~km}$, which these authors correlate with a strongly sheared and displaced subducted slab. These seismic profiles suggest a possible break in the zone at near $400 \mathrm{~km}$ depth; if this represents the front of a newer descending slab, then it is consistent with a subduction jump at $\sim 6 \mathrm{Ma}$ (using the data from Jarrard, 1986), and would imply that the deeper seismicity would represent the remnants of the previously subducted slab. It is significant that the seismic profiles of Louat and Dupont (1982) also show slab imbrication at depths of $>500 \mathrm{~km}$. Alternatively, the inferred age of 9.6-10 Ma for the whole of the Tongan slab is still consistent with the inferred age of initial Lau Basin extension (between 5.5 and a maximum of $10 \mathrm{Ma}$; Parson and Hawkins, this volume), implying that the original, but now inactive, Lau-Tonga Ridge subducted slab is no longer detectable through active seismicity.

Figure 26 summarizes the inferred evolution of the Lau Basin. The sequence of mantle streamlines is based on the premise that the processes of backarc magma generation are responsible for the inferred depletion of the mantle wedge, which, in turn, convects into the region beneath the active arc volcanism from which arc magmas (and bonin- 
REGIONAL GEOCHEMISTRY OF LAU-TONGA SYSTEMS
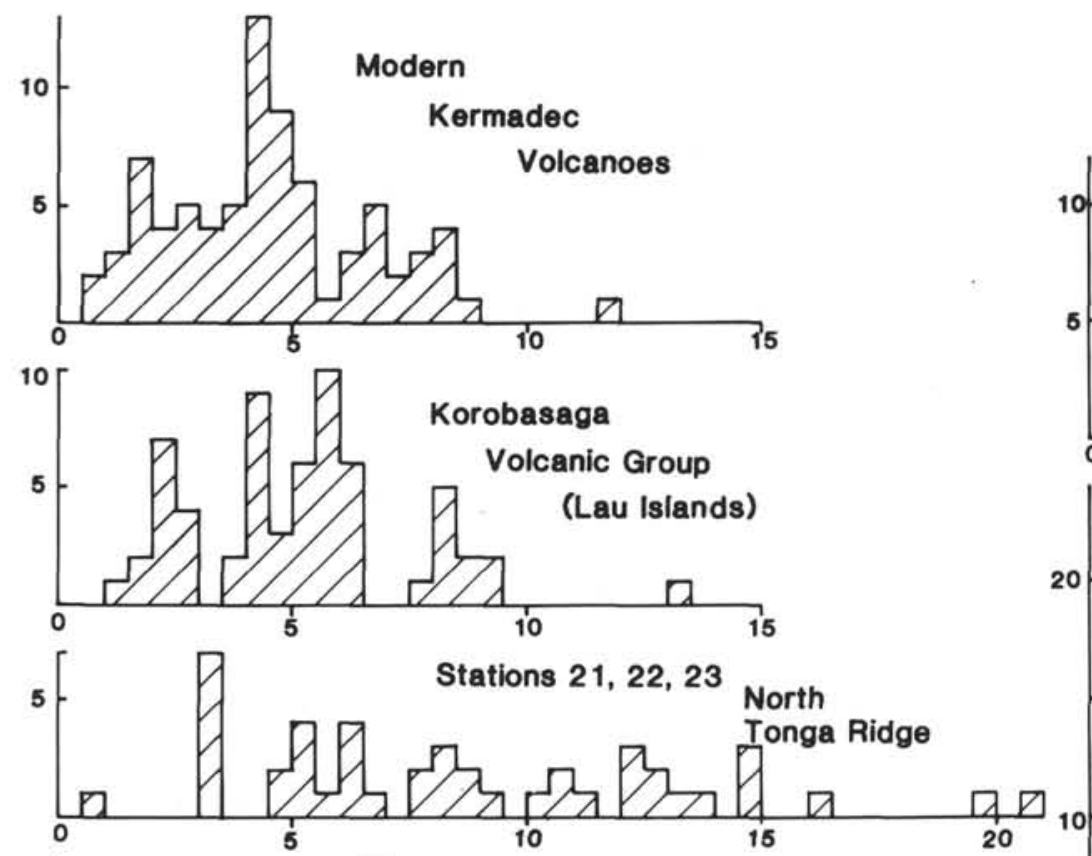

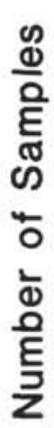

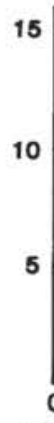

Site 839

(including glasses)

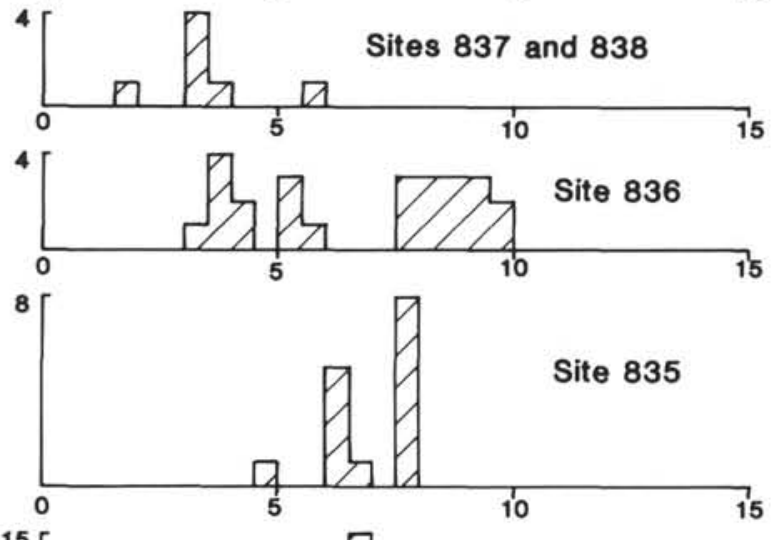

15
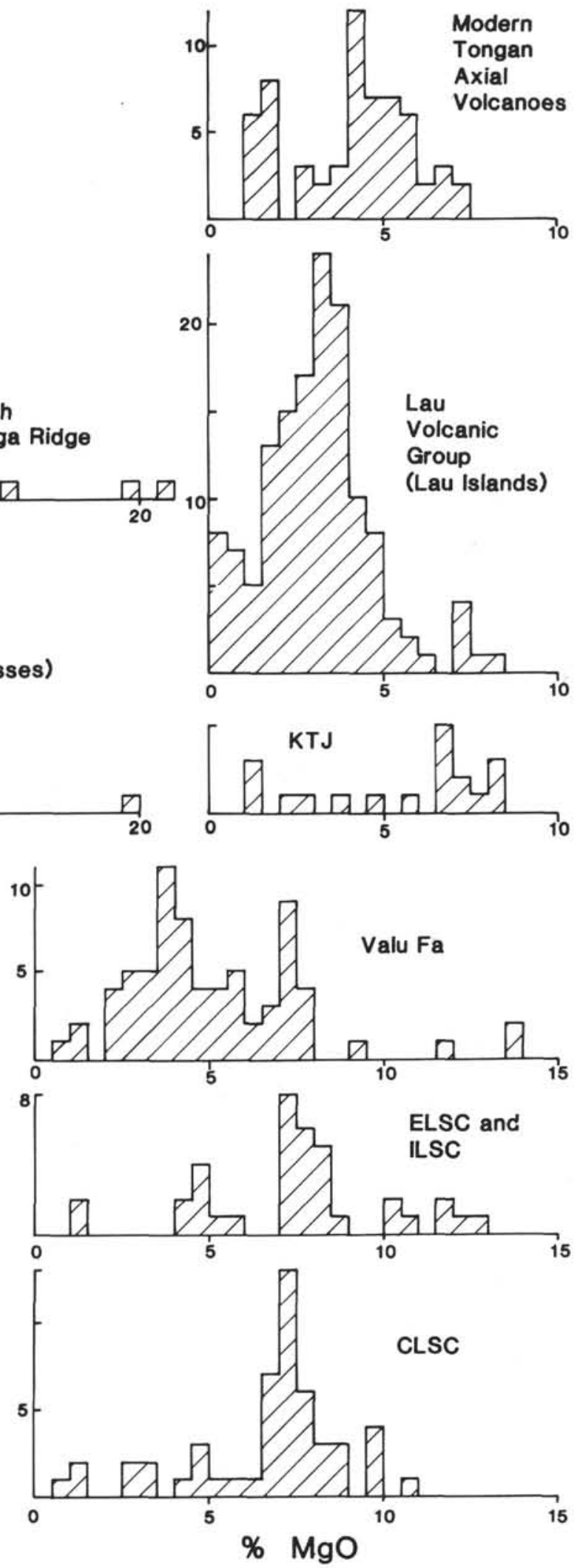

Figure 8. Histograms illustrating the distribution of $\% \mathrm{MgO}$ in lavas from Sites 834 to 839 , the Lu Basin Spreading Centers and the Eau Ridge, the modern Tongan and Kermadec arc volcanoes, and the northern Tongan boninitic series.

403 

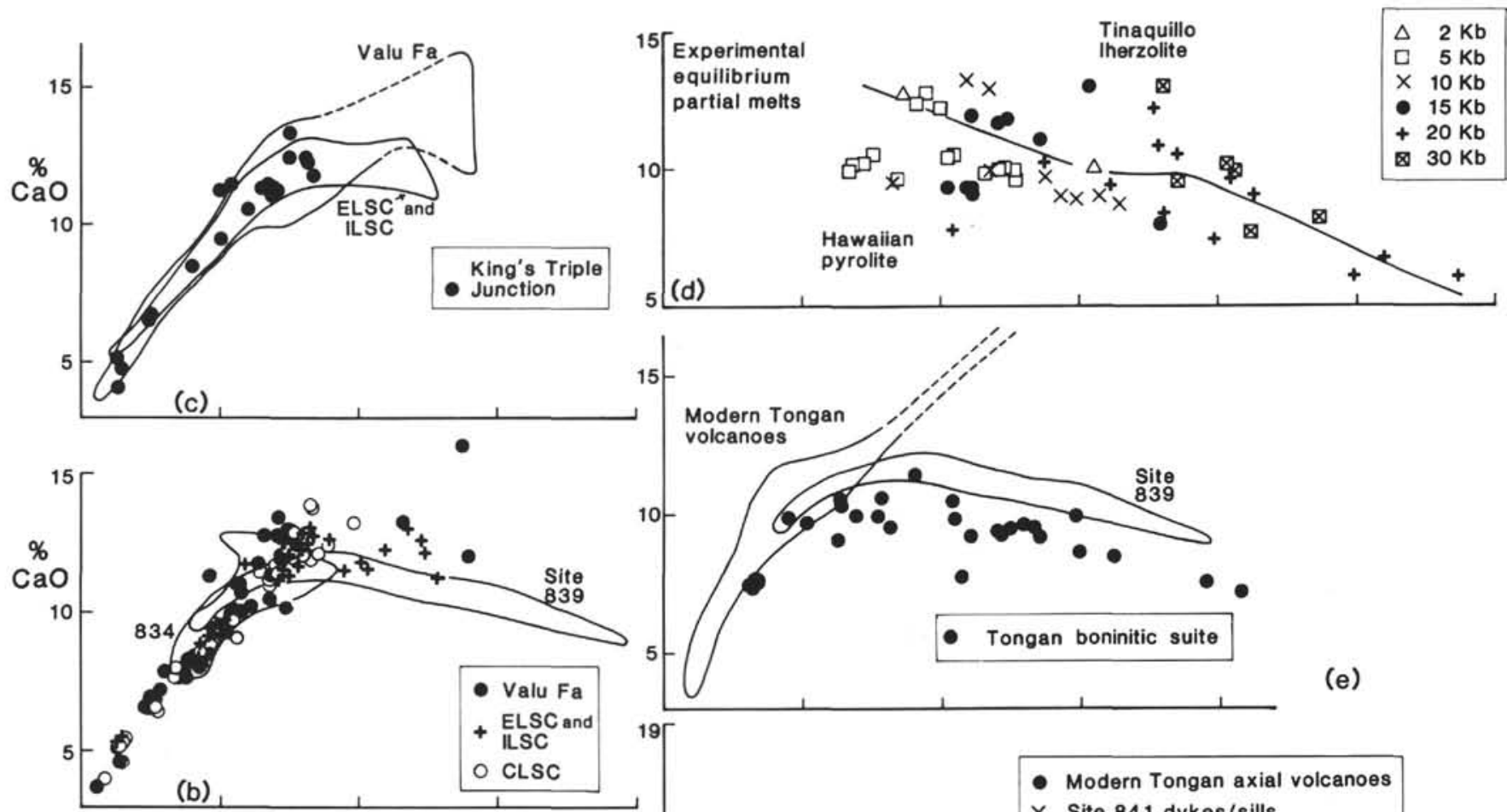

volcanoes

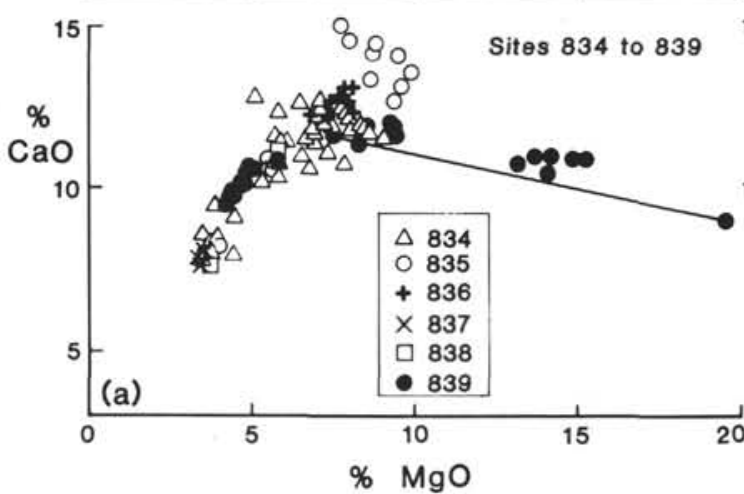

Modern Tongan axial volcanoes

$\times$ Site 841 dykes/sills

Figure 9. Compilation of $\mathrm{CaO}-\mathrm{MgO}$ data comparing lavas of the modern Lau Basin spreading centers, Sites 834-839 and 841, the modern Tonga-Kermadec volcanoes, and the northern Tongan boninites. Also shown are the experimental equilibrium liquids, at various pressures, after Falloon et al. (1988). The tie-line joins a coexisting whole rock-matrix pair.

Table 6. Partition coefficients used in fractional melting models (Fig. 21, Models 1-4).

\begin{tabular}{|c|c|c|c|c|c|c|c|c|c|}
\hline & Olivine $^{\mathrm{a}}$ & Olivine $^{\mathrm{b}}$ & Orthopyroxene ${ }^{a}$ & Orthopyroxene ${ }^{b}$ & Clinopyroxene $^{a}$ & Clinopyroxene ${ }^{b}$ & Spinel $^{c}$ & Spinel $^{d}$ & Amphibole \\
\hline $\mathrm{Rb}, \mathrm{K}$ & 0.0002 & 0.0002 & 0.0006 & 0.01 & 0.011 & 0.004 & 0.0001 & 0.0001 & 0.2 \\
\hline $\mathrm{Ba}$ & 0.0086 & 0.0001 & 0.014 & 0.01 & 0.077 & 0.005 & 0.0001 & 0.0001 & 0.33 \\
\hline $\mathrm{Sr}$ & 0.05 & 0.0002 & 0.007 & 0.01 & 0.067 & 0.086 & 0.0001 & 0.0001 & 0.12 \\
\hline Th & 0.014 & 0.01 & 0.0001 & 0.05 & 0.152 & 0.05 & 0.02 & 0.02 & 0.60 \\
\hline $\mathrm{Nb}$ & 0.01 & 0.01 & 0.02 & 0.03 & 0.05 & 0.04 & 0.01 & 0.01 & 0.80 \\
\hline $\mathrm{La}$ & 0.0018 & 0.0005 & 0.238 & 0.029 & 0.158 & 0.082 & 0.029 & 0.029 & 0.17 \\
\hline $\mathrm{Ce}$ & 0.0018 & 0.0008 & 0.20 & 0.031 & 0.223 & 0.096 & 0.032 & 0.032 & 0.26 \\
\hline Nd & 0.0018 & 0.0013 & 0.144 & 0.034 & 0.36 & 0.182 & 0.041 & 0.037 & 0.44 \\
\hline $\mathrm{Zr}$ & 0.10 & 0.023 & 0.05 & 0.04 & 0.25 & 0.14 & 0.02 & 0.02 & 0.40 \\
\hline $\mathrm{Hf}$ & 0.10 & 0.022 & 0.01 & 0.04 & 0.233 & 0.21 & 0.02 & 0.02 & 0.50 \\
\hline $\mathrm{Sm}$ & 0.0019 & 0.0019 & 0.144 & 0.047 & 0.36 & 0.261 & 0.041 & 0.053 & 0.76 \\
\hline $\mathrm{Eu}$ & 0.0019 & 0.0019 & 0.141 & 0.06 & 0.424 & 0.26 & 0.053 & 0.063 & 0.88 \\
\hline $\mathrm{Ti}$ & 0.006 & 0.006 & 0.024 & 0.024 & 0.10 & 0.10 & 0.048 & 0.048 & 0.69 \\
\hline $\mathrm{Yb}$ & 0.0094 & 0.004 & 0.257 & 0.244 & 0.563 & 0.227 & 0.10 & 0.11 & 0.59 \\
\hline $\mathrm{Lu}$ & 0.0118 & 0.0048 & 0.28 & 0.300 & 0.55 & 0.19 & 0.105 & 0.091 & 0.51 \\
\hline
\end{tabular}

Notes: Partition coefficents slightly modified from McKenzie and O'Nions (1991) and Ewart and Hawkesworth (1987).

${ }^{a}$ Models 1 and 2.

${ }^{b}$ Models 3 and 4 .

c Model 1 .

${ }^{\mathrm{d}}$ Model 3

e Models 2 and 4. 


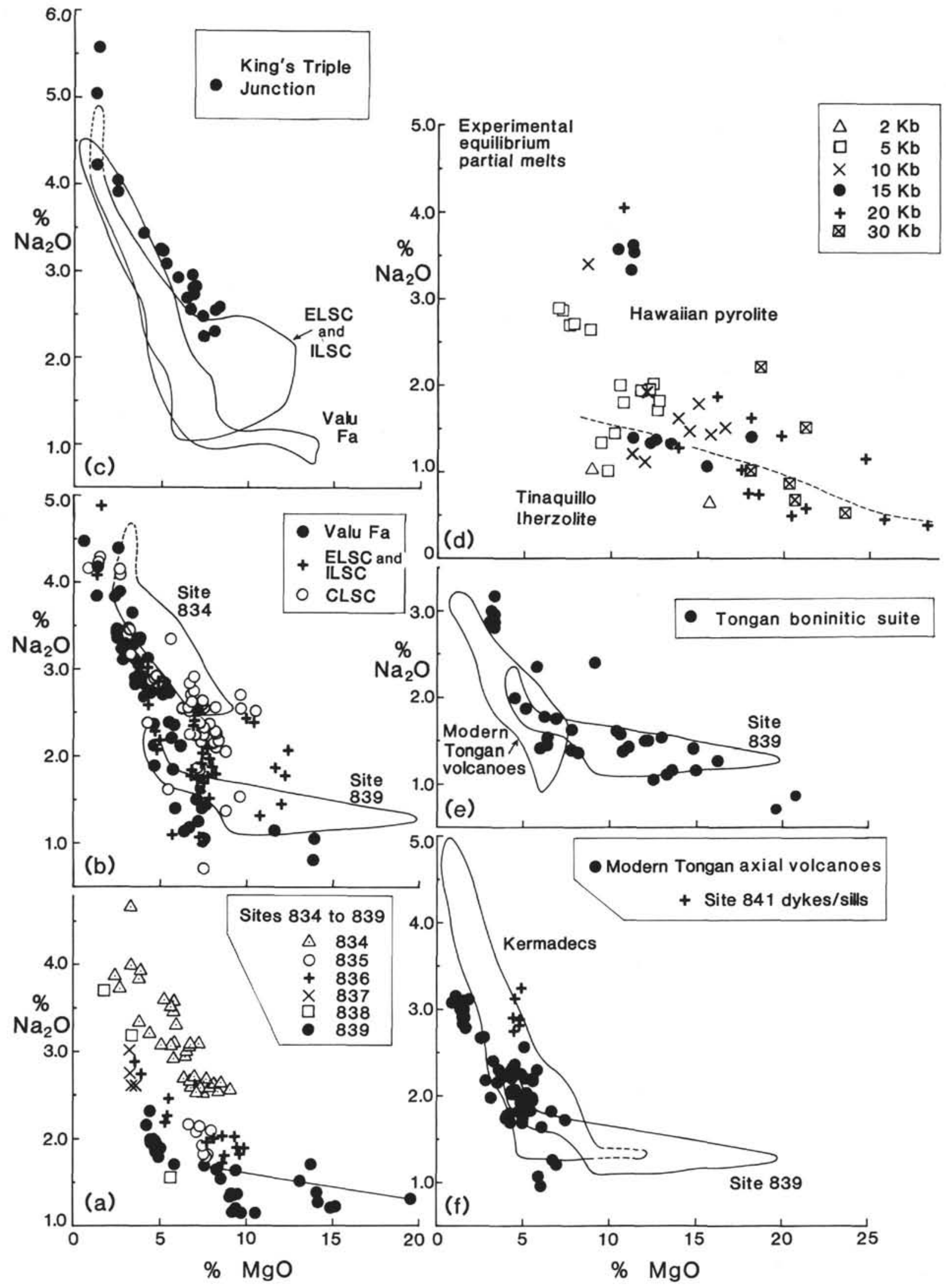

Figure 10. Compilation of $\mathrm{Na}_{2} \mathrm{O}-\mathrm{MgO}$ data, as in Figure 9. 

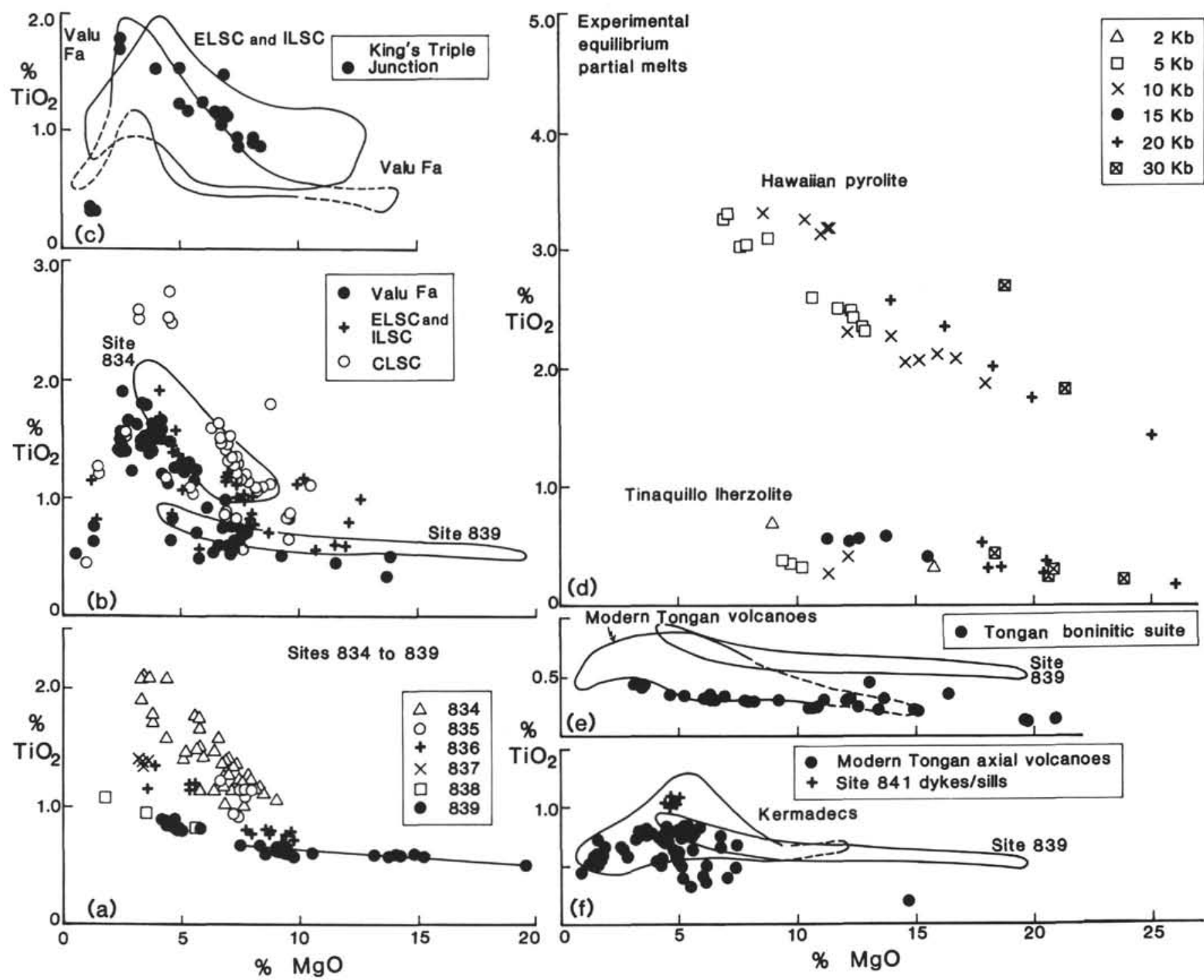

(d)

Tinaquillo Iherzolite

Modern Tengan volcanoes
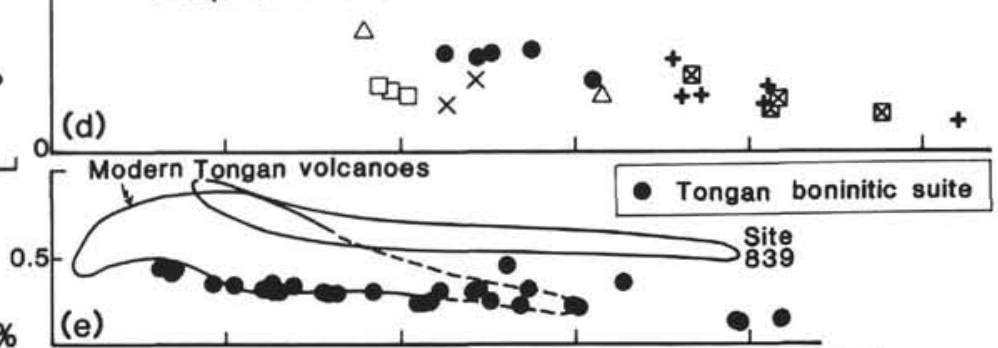

Figure 11. Compilation of $\mathrm{TiO}_{2}-\mathrm{MgO}$ data, as in Figure 9.

ites) are themselves derived. Thus, the most intensive zones of source depletion (i.e., most refractory sources) are correlated with the widest zones of backarc magmatism, that is, toward the northern end of the Tonga Ridge and increasing northward within the Kermadec Arc. It is further noted that there appears to be, and in fact is predicted to be, a net increase in the refractory character of the source of the arc magmas toward the east, with the Lau Ridge arc magmas sourced from less refractory mantle than those of Tonga. It is noted, however, that the streamlines shown in Figure 26 do not coincide with those predicted by recent geophysical modeling (e.g., Spiegelman and McKenzie, 1987), although both models still require focusing of streamlines into the volcanic front. Such geophysically modeled streamline configurations are not easily reconciled into the coupled arc-backarc systems inferred here to operate in the Lau-Tonga system.

The effect of increasing proximity to the modern Tonga subduction zone, and the arc volcanism, is suggested as the reason for the change of geochemical character of the ELSC lavas (weak arc signatures) toward the Valu Fa Ridge (strong arc signatures); the younger CLSC magmas now occurring in the central Lau Basin are geochemically nearer N-MORB. The development of arc-like signatures in the lavas from Sites 835,837 , and 838 are similarly attributed to their closer proximity to the Tongan subduction zone during eruption, be- fore the propagator activity displacing the arc and subduction zone further eastward.

It is further suggested that the development of the Lau Basin, with its consequent net eastward movement of the Tongan-Kermadec arcs, is just the latest stage in the progressive eastward fragmentation of the southwest Pacific arc systems, resulting in stranded extinct arcs (e.g., Loyality and Three Kings arcs) and accompanying basins (e.g., South Fiji Basin), as outlined by Kroenke (1984).

\section{ACKNOWLEDGMENTS}

We thank the staff and crew of the JOIDES Resolution and Ocean Drilling Program for their enthusiastic and skilled work during the Leg 135 drilling. Analytical work on which this paper is based were conducted at the Departments of Earth Sciences at Monash University, University of Queensland, and Australian National University. Thanks are owed to the staff in these departments for extensive assistance. Mrs E. Burdin, University of Queensland, drafted all figures. The manuscript received much technical and editorial assistance and improvement from reviews by Profs. J. Cole and J. Hawkins, Dr. C.J. Stephens, ODP editorial staff, and an unnamed reviewer. Part of this research was funded by a Special Project Grant, University of Queensland. 


\section{REFERENCES}

Baker, P.E., Harris, P.G., and Reay, A., 1971. The geology of Tofua Island, Tonga. In Cook Bicentenary Expedition in the South-West Pacific. Bull.R. Soc. N.Z., 8:67-69.

Bauer, G.R., 1970. The geology of Tofua Island, Tonga. Pac. Sci., 24:333-350.

Boespflug, X., Dosso, L., Bougault, H., and Joron, J.L., 1990. Trace element and isotopic ( $\mathrm{Sr}$ and $\mathrm{Nd}$ ) geochemistry of volcanic rocks from the Lau Basin. In von Stackelberg, U., and von Rad, U. (Eds.), Geological Evolution and Hydrothermal Activity in the Lau and North Fiji Basins, Southwest Pacific Ocean (Results of SONNE Cruise SO-35). Geol. Jahrb. 92:503-516.

Chappell, B.W., and Hergt, S.M., 1989. The use of known Fe content as a flux monitor in neutron activation analysis. Chem. Geol., 78:151-158.

Chayes, F., and Velde, D., 1965. On distinguishing basaltic lavas of circumoceanic and oceanic-island type by means of discriminant functions. Am. J. Sci., 263:206-222.

Cole, J.W., Gill, J.B., and Woodhall, D., 1985. Petrologic history of the Lau Ridge, Fiji. In Scholl, D.W., and Vallier, T.L. (Eds.), Geology and Offshore Resources of Pacific Island Arcs-Tonga Region. Circum-Pac. Counc. Energy Miner. Resour., Earth Sci. Ser., 2:379-414.

Cole, J.W., Graham, I.J., and Gibson, I.L., 1990. Magmatic evolution of Late Cenozoic volcanic rocks of the Lau Ridge, Fiji. Contrib. Mineral. Petrol., 104:540-554

Collier, J., and Sinha, M., 1990. Seismic images of a magma chamber beneath the Lau Basin back-arc spreading center. Nature, 346:646-648.

Duncan, R.A., and Green, D.H., 1987. The genesis of refractory melts in the formation of oceanic crust. Contrib. Mineral. Petrol., 96:326-342.

Ernewein, M., Pearce, J.A., Bloomer, S.H., Parson, L.M., Murton, B.J., and Johnson, L.E., in press. Geochemistry of Lau Basin volcanic rocks: influence of ridge segmentation and arc proximity. In Smellie.. J. (Ed.), Volcanism Associated with Extension at Consuming Plate Margins. Geol. Soc. Spec. Publ. London.

Ewart, A., 1976. A petrological study of the younger Tongan andesites and dacites and olivine tholeiites of Niuafo'ou Island, S.W. Pacific. Contrib. Mineral. Petrol., 58:1-21.

Ewart, A., Brothers, R.N., and Mateen, A., 1977. An outline of the geology and geochemistry, and the possible petrogenetic evolution of the volcanic rocks of the Tonga-Kermadec-New Zealand island arc. J. Volcanol. Geotherm. Res., 2:205-250.

Ewart, A., Bryan, W.B., and Gill, J., 1973. Mineralogy and geochemistry of the younger volcanic islands of Tonga, southwest Pacific. J. Petrol., $14: 429-465$.

Ewart, A., and Hawkesworth, C.J., 1987. The Pleistocene-Recent Tonga-Kermadec arc lavas: interpretation of new isotope and rare earth data in terms of a depleted mantle source model. J. Petrol., 28:495-530.

Falloon, T.J., and Crawford, A.J., 1991. The petrogenesis of high-calcium boninite lavas dredged from the northern Tonga ridge. Earth Planet. Sci. Lett., 102:375-394.

Falloon, T.J., Green, D.H., and Crawford, A.J., 1987. Dredged igneous rocks from the northern termination of the Tofua magmatic arc. Tonga and adjacent Lau Basin. Aust. J. Earth Sci., 34:487-506.

Falloon, T.J., Green, D.H., Hatton, C.J., and Harris, K.L., 1988. Anhydrous partial melting of a fertile and depleted peridotite from 2 to $30 \mathrm{~Kb}$ and application to basalt petrogenesis. J. Petrol., 29:1257-1282.

Falloon, T.J., Green, D.H., McCulloch, M.T., 1989. Petrogenesis of high-Mg and associated lavas from the north Tonga trench. In Crawford, A.J. (Ed.), Boninites and Related Rocks: London (Unwin Hyman), 357-395.

Falloon, T.J., Malahoff, A., Zonenshain, L.P., and Bogdanov, Y., 1992. Petrology and geochemistry of back-arc basin basalts from Lau Basin spreading ridges at 15,18 , and $19^{\circ}$ S. Mineral. Petrol., 47:1-35.

Frenzel, G., Mühe, R., and Stoffers, P., 1990. Petrology of volcanic rocks from the Lau Basin, Southwest Pacific. Geol. Jahrb., Riehe D, 92:395-479.

Giardini, D., and Woodhouse, J., 1984. Deep seismicity and modes of deformation in Tonga subduction zone. Nature, 307:505-509.

Gill, J.B., 1976. Composition and age of Lau basin and ridge volcanic rocks: implications for evolution of an interarc basin and remnant arc. Geol. Soc. Am. Bull., 87:1384-1395.

\footnotetext{
Abbreviations for names of organizations and publication titles in ODP reference lists follow the style given in Chemical Abstracts Service Source Index (published by American Chemical Society).
}

, 1981. Orogenic Andesites and Plate Tectonics: New York (Springer-Verlag)

Grove, T.L., and Bryan, W.B., 1983. Fractionation of pyroxene-phyric MORB at low pressure: an experimental study. Contrib. Mineral. Petrol., 84:293-309.

Grove, T.L., Gerlach, D.C., and Sando, T.W., 1982. Origin of calc-alkaline series lavas at Medicine Lake Volcano by fractionation, assimilation and mixing. Contrib. Mineral. Petrol., 80:160-182.

Hart, S.R., and Reid, M.R., 1991. Rb/Cs fractionation: a link between granulite metamorphism and the S-process. Geochim. Cosmochim. Acta, 55:23792838.

Hawke, M.M., 1983. Mineralogy of some igneous rocks from the Kermadec Islands and Taupo Volcanic Zone, New Zealand [unpubl. Ph.D. thesis]. Univ. of Auckland, New Zealand.

Hawkins, J.W., 1976. Petrology and geochemistry of basaltic rocks of the Lau Basin. Earth Planet. Sci. Lett., 28:283-297.

Hawkins, J.W., and Melchior, J.T., 1985. Petrology of Mariana Trough and Lau Basin basalts. J. Geophys. Res., 90:11431-11468.

Hofmann, A.W., 1988. Chemical differentiation of the Earth: the relationship between mantle, continental crust, and oceanic crust. Earth Planet. Sci. Lett., 90:297-314.

Jarrard, R.D., 1986. Relations among subduction parameters. Rev. Geophys. $24: 217-284$

Jenner, G.A., Cawood, P.A., Rautenschlein, M., and White, W.M., 1987 Composition of back-arc basin volcanics, Valu Fa Ridge, Lau Basin evidence for a slab-derived component in their mantle source. J. Volcanol. Geotherm. Res., 32:209-222.

Jochum, K.P., Seufert, H.M., Spettel, B., and Palme, H., 1986. The solar-system abundances of $\mathrm{Na}, \mathrm{Ta}$, and $\mathrm{Y}$, and the relative abundances of refractory lithophile elements in differentiated planetary bodies. Geochim. Cosmochim. Acta, 50:1173-1183.

Jochum, K.P., Seufert, H.M., and Thirlwall, M.F., 1990. High-sensitivity Nb analysis by spark-source mass spectrometry (SSMS) and calibration of XRF Nb and Zr. Chem. Geol., 81:1-16.

Johnstone, R.D., 1978. 'Ata, the most southerly volcanic island in Tonga. In Lau-Tonga 1977. Bull.-R. Soc. N.Z., 17:153-164.

Kay, R.W., and Hubbard, N.J., 1978. Trace elements in ocean ridge basalts. Earth Planet. Sci. Lett., 38:95-116.

Kroenke, L.W., 1984. Cenozoic Tectonic Development of the Southwest Pacific. U.N. Econ. Soc. Comm. Asia Pac., Suva, Fiji. CCOP/SOPAC, Tech. Bull., 6.

Loock, G., McDonough, W.F., Goldstein, S.L., and Hofmann, A.W., 1990. Isotopic compositions of volcanic glasses from the Lau Basin. Mar. Min. 9:235-245.

Louat, R., and Dupont, J., 1982. Sismicité de L'arc des Tonga-Kermadec. In Equipe de Géologie-Geophysique du Centre ORSTOM de Nouméa. Contrib. à l'étude geodynamique du Sud-Ouest Pacifique, Trav. Doc. ORSTOM, 147:299-317.

McDonough, W.F., Sun, S.-S., Ringwood, A.E., Jagoutz, E., and Hofmann, A.W., 1992. Potassium, rubidium, and cesium in the Earth and Moon and the evolution of the mantle of the Earth. Geochim. Cosmochim. Acta, 56:1001-1012.

McKenzie, D., and O'Nions, R.K., 1991. Partial melt distributions from inversion of rare earth element concentrations. J. Petrol., 32:1021-1091.

Melson, W.G., Jarosewich, E., and Lundquist, C.A., 1970. Volcanic eruption at Metis Shoal, Tonga, 1967-1968. Description and petrology. Smithson. Contrib. Earth Sci., 4.

Norrish, K., and Hutton, J.T., 1969. An accurate X-ray spectrographic method for the analysis of a wide range of geological samples. Geochim. Cosmochim. Acta, 33:431-453.

Oversby, V.M., and Ewart, A., 1972. Lead isotopic compositions of TongaKermadec volcanics and their petrogenetic significance. Contrib. Miner. Petrol., 37:181-210.

Parson, L., Hawkins, J., Allan, J., et al., 1992. Proc. ODP, Init. Repts., 135: College Station, TX (Ocean Drilling Program).

Parson, L.M., Pearce, J.A., Murton, B.J., Hodkinson, R.A., Bloomer, S. Ernewein, M., Huggett, Q.J., Miller, S., Johnson, L., Rodda, P., and Helu, S., 1990. Role of ridge jumps and ridge propagation in the tectonic evolution of the Lau back-arc basin, southwest Pacific. Geology, 18:470-473.

Reay, A., Rooke, J.M., Wallace, R.C., and Whelan, P., 1974. Lavas from Niuafo'ou Island, Tonga, resemble ocean-floor basalts. Geology, 2:605606.

Scholl, D.W., Vallier, T.L., and Maung, T.U., 1985. Introduction. In Scholl, D.W., and Vallier, T.L. (Eds.), Geology and Offshore Resources of the Pacific Island Arcs-Tonga Region. Circum-Pac. Counc. Energy Miner. Resour., Earth Sci. Ser., 2:3-15. 
Spiegelman, M., and McKenzie, D.P., 1987. Simple 2-D models for melt extraction at mid-ocean ridges and island arcs. Earth Planet. Sci. Lett., $83: 137-152$

Sun, S.-S., and McDonough, W.F., 1989. Chemical and isotopic systematics of oceanic basalts: implications for mantle composition and processes. In Saunders, A.D., and Norry, M.J. (Eds.), Magmatism in the Ocean Basins. Geol. Soc. Spec. Publ. London, 42:313-345.

Sunkel, G., 1990. Origin of petrological and geochemical variations of Lau Basin lavas (SW Pacific). Mar. Min., 9:205-234.

Tao, G.Y., Pella, P.A., and Rousseau, R.M., 1985. NBSGSC-a fortran program for quantitative X-ray fluorescence analysis. NBS Tech. Note (U.S.), 1213:124.

Taylor, S.R., and Gorton, M.P., 1977. Geochemical application of spark source mass spectrometry. III. Element sensitivity, precision and accuracy. Geochim. Cosmochim. Acta, 41:1375-1380.

Vallier, T.L., Jenner, G.A., Frey, F., Gill, J., Davis, A.S., Hawkins, J.W., Morris, J.D., Cawood, P.A., Morton, J., Scholl, D., Rautenschlein, M., White, W.M., Williams, R.W., Volpe, A.M., Stevenson, A.J., and White, L.D., 1991. Subalkaline andesite from Valu Fa Ridge, a back arc spreading center in southern Lau Basin: petrogenesis, comparative chemistry, and tectonic implication. Chem. Geol., 91:227-256.

Vallier, T.L., Stevenson, A.J., and Scholl, D.W., 1985. Petrology of igneous rocks from 'Ata Island, Kingdom of Tonga. In Scholl, D.W., and Vallier, T.L. (Eds.), Geology and Offshore Resources of Pacific Island ArcsTonga Region. Circum-Pac. Counc. Energy Miner. Resour., Earth Sci. Ser. 2:301-316.

Viereck, L.G., Flower, M.F.J., Hertogen, J., Schmincke, H.-U., and Jenner, G.A., 1989. The genesis and significance of N-MORB sub-types. Contrib. Mineral. Petrol., 102:112-126.

Volpe, A.M., Macdougall, J.D., and Hawkins, J.W., 1988. Lau basin (LBB): trace element and $\mathrm{Sr}$-Nd isotopic evidence for heterogeneity in backarc basin mantle. Earth Planet. Sci. Lett., 90:174-186.

von Stackelberg, U., and Shipboard Scientific Party, 1985. Hydrothermal sulphide deposits in back-arc spreading centres in the southwest Pacific. Bundesanst. Geowiss. Rohstoffe Circ., 2:3-14.

, 1988. Active hydrothermalism in the Lau back-arc basin (SW Pacific): first results from the Sonne 48 cruise (1987). Mar. Min., 7:431-442.

\section{Date of initial receipt: 29 June 1992 \\ Date of acceptance: 14 June 1993 \\ Ms 135SR-141}

\section{APPENDIX}

\section{Analytical Techniques}

Atomic Absorption Graphite Furnace Methods: $\mathrm{Pb}$ : Sample digested in $\mathrm{HF} / \mathrm{HNO}_{3}$ and fumed to dryness 4 times with $\mathrm{HNO}_{3}$ to convert to nitrates. After making up to volume, analyzed in a Perkin Elmer HGA300 graphite furnace and AS40 autosampler fitted to a Perkin Elmer 2380 AAS using peak area measurement. $\mathrm{A} \mathrm{Pb}$ hollow cathode lamp and deuterium background corrector were used, with matrix modification using $\mathrm{NH}_{4} \mathrm{H}_{2} \mathrm{PO}_{4}$, at a wavelength of $217.0 \mathrm{nM}$.

$\mathrm{Be}: 100 \mathrm{mg}$ of rock powder digested in $\mathrm{HF} / \mathrm{HNO}_{3}$ and fumed down 4 times with $\mathrm{HNO}_{3}$ to convert all fluorides to nitrates. Analyzed by a Perkin Elmer HGA300 graphite furnace with AS40 autosampler on a 2380 AAS. The parameters used were as follows: 15-mA lamp current plus $\mathrm{D}_{2}$ background corrector at $234.9 \mathrm{nM}$; L'vov platform; $20 \mu \mathrm{L}$ of sample plus $10 \mu \mathrm{L}$ of 2500 ppm $\mathrm{Mg}\left(\mathrm{NO}_{3}\right)_{2}$ used as matrix modifier. Detection limit approximately 0.05 $\mathrm{ppm} \mathrm{Be}$ in rock.

ICP-MS method: Approximately $0.1 \mathrm{~g}$ of sample was weighted out accurately into a $100-\mathrm{cm}^{3}$ PTFE beaker. Samples were digested on a hot plate using ultrapure $\mathrm{HF}$ followed by $\mathrm{HNO}_{3}$. The resultant nitrates were taken up in $25-\mathrm{cm}^{3} 0.5 \%$ nitric acid. The samples were made up to $100-\mu \mathrm{g} \mathrm{dm}{ }^{-3}$ with respect to indium (internal standard) and analyzed by ICP-MS (PQ2+ PlasmaQuad VG Elemental, England) in "peak jumping mode." Standards of 0.05, 0.1 , and $0.2 \mathrm{mg} \mathrm{BHVO}-1$ and RGM-1 were used to construct calibration curves. Experimental conditions were as follows: number of peak jump sweeps $=100$, points per peak $=5$, and Dac steps between points $=5$.

Electron microprobe: Mineral analyses were performed on a newly installed, fully automatic, JEOL Superprobe, at the University of Queensland Centre for Microscopy and Microanalysis. Standards comprised international oxide and mineral standards, 20 - to 30 -s count times, and $1-\mu \mathrm{m}$ focused beam (10 $\mu \mathrm{m}$ for feldspars and glasses). Full ZAF correction procedures were applied.

$X$-ray Fluorescence: Major elements were analyzed on glass discs prepared from samples weighed with lithium borate flux. Trace elements were analyzed on pressed discs, prepared from $6 \mathrm{~g}$ of powdered sample. Methods follow those described by Norrish and Hutton (1969), with major element data processing using NBS/TN-1213 software package (Tao et al., 1985). Absorption coefficients are applied to the trace element analyses by calculation from the major element analyses with correction procedures following the University of Cape Town software (A.R. Duncan, pers. comm., 1991).

INAA: Methods and instrumentation followed those described in Chappell and Hergt (1989).

SSMS Method: The method used here follows that of Taylor and Gorton (1977). About $150 \mathrm{mg}$ of powder was mixed with the same amount of graphite, which contains $\mathrm{Lu}$ (used as an internal standard) and spikes for $\mathrm{Ba}, \mathrm{Nd}$, and $\mathrm{Pb}$. This mixture was then pressed into electrodes that were analyzed on the MS7 double-focusing mass spectrometer, which employs photoplates for detection purposes. At least three photoplates were analyzed for each sample and the results were pooled. Accuracy, based on replicate analyses of international standards, is $\pm 10 \%$ for all elements except $\mathrm{Rb}$ and $\mathrm{Sr}$, which are accurate to within $20 \%$. Precision is generally better than $\pm 5 \%$ ( 2 sigma), although elements at very low or very high concentrations will have poorer precision because of the fewer number of data points that are pooled-ideally, a minimum of 20 separate determinations are used in the final results. Recent improvements to the MS7 have resulted in resolution of an interference on ${ }^{93} \mathrm{Nb}$ (because of ${ }^{29} \mathrm{Si}^{16} \mathrm{O}_{4}$; Jochum et al., 1990), which, if left unresolved, would most greatly affect samples with low $\mathrm{Nb}$ concentrations (i.e., $<1 \mathrm{ppm}$ ).

\section{Comparison of Analytical Methods}

Six samples were measured by three separate methods (i.e., ICP-MS, INAA, and SSMS), allowing comparison of results for overlapping elements, namely, $\mathrm{Ba}$, Hf, and the REEs.

For the REEs, all three analytical techniques yield results that are generally within $10 \%$ of one another, with no systematic bias displayed by any individual technique. An exception to this is Ce, where the SSMS data appear to be systematically high by $5 \%-15 \%$ when compared with those from ICP-MS or INAA.

The Ba data are within $10 \%$ for SSMS and ICP-MS. The INAA Ba is similar to that from ICP-MS and SSMS at higher concentrations; however, below $\sim 50 \mathrm{ppm}$ the INAA data tend to be higher than either ICP-MS or SSMS data. This general trend is preserved when one examines the other samples for which both ICP-MS and INAA data are available; the INAA Ba is generally higher (by up to a factor of 3 ) than the ICP-MS Ba for rocks with $<50 \mathrm{ppm}$.

$\mathrm{Hf}$ shows the poorest comparison between the three techniques, with overall variation of up to a factor of 2 , but with most results falling within $\pm 20 \%$. The ICP-MS data are consistently higher than the SSMS data. The INAA data are similar to the SSMS data at high $\mathrm{Hf}$ concentrations $(>0.9 \mathrm{ppm})$, but they show much lower values at lower levels compared with either the ICP-MS or SSMS data. Some estimate of the relative accuracy of these disparate measurements may be gained by comparing $\mathrm{Zr} / \mathrm{Hf}$ ratios. For these samples, $\mathrm{Zr}$ was measured by XRF and SSMS, and the data generally reproduced within $10 \%$. Thus, little variation in the $\mathrm{Zr} / \mathrm{Hf}$ ratio will be produced because of variation in the $\mathrm{Zr}$ data. The $\mathrm{Zr} / \mathrm{Hf}$ ratios measured by the ICP-MS are between 36 and 39 , whereas the SSMS Zr/Hf ratios lie between 35 and 44 , with the exception of one sample (135-839B-25R-1, 33-41 cm) that has a $\mathrm{Zr} / \mathrm{Hf}$ ratio of 51 (cf. 38 from ICP-MS). These values are not significantly different from the chondritic ratio of 36 (Jochum et al., 1986), although the ICP-MS results show less variation and are generally closer to the chondritic value, suggesting that the ICP-MS Hf data may be more accurate. The INAA results at high concentrations also have near-chondritic $\mathrm{Zr} / \mathrm{Hf}(41-44)$. However, the low INAA Hf results produce very high $\mathrm{Zr} / \mathrm{Hf}$ (83-116), suggesting that these $\mathrm{Hf}$ values are too low.

In addition to the comparisons made above, $\mathrm{Cs}, \mathrm{Rb}, \mathrm{Sr}, \mathrm{Zr}, \mathrm{Nb}, \mathrm{Y}, \mathrm{W}, \mathrm{U}$, $\mathrm{Th}$, and $\mathrm{Pb}$ have all been measured by SSMS and either ICP-MS (Cs, Nb, W, $\mathrm{U}$, and $\mathrm{Th}), \mathrm{XRF}(\mathrm{Rb}, \mathrm{Sr}, \mathrm{Zr}$, and $\mathrm{Y}$ ) or $\mathrm{AA}(\mathrm{Pb}) . \mathrm{Rb}, \mathrm{Zr}$, and $\mathrm{Y}$ compare well between the different techniques, with overall variations generally less than $10 \% ; \mathrm{Sr}$ is generally within $20 \%$. Th and $\mathrm{U}$ vary by as much as $70 \%$, with SSMS U generally lower than ICP-MS values. W varies by as much as a factor of 3 , with SSMS W consistently higher than ICP-MS W. Cs varies by a factor of 3 between SSMS and ICP-MS. Because XRF and SSMS Rb concentrations compare well, the $\mathrm{Rb} / \mathrm{Cs}$ ratio may be used to evaluate the reliability of the $\mathrm{Cs}$ results. Arc rocks have Rb/Cs ratios between 10 and 40 (Hart and Reid, 1991; 
McDonough et al., 1992). The arc-related samples measured here have $\mathrm{Rb} / \mathrm{Cs}$ $=27-143$ for ICP-MS Cs or Rb/Cs $=22-48$ for SSMS Cs. The single sample that gave comparable Cs from SSMS and ICP-MS (135-839B-23R-1, 0-6 cm, with $\mathrm{Cs}=0.11$ [CM-PS] or 0.105 [SSMS]) has $\mathrm{Rb} / \mathrm{Cs}=37$ (SSMS) or 45 (ICM-PS). Based on these observations, the SSMS Cs would appear to be more accurate. $\mathrm{Nb}$ varies by as much as a factor of 1.8 , with the SSMS data generally higher than the ICP-MS data. Despite this variability, all six samples show high $\mathrm{La} / \mathrm{Nb}$ ratios, similar to arc basalts. Finally, $\mathrm{Pb}$ data vary by as much as a factor of 2.4. In general, the SSMS data are lower than the AA data, with results from only one sample falling within $10 \%$ of each other. The reason for this variability is not known, but if it is a result of contamination, then the lower values (i.e., the SSMS data) would be the more accurate.

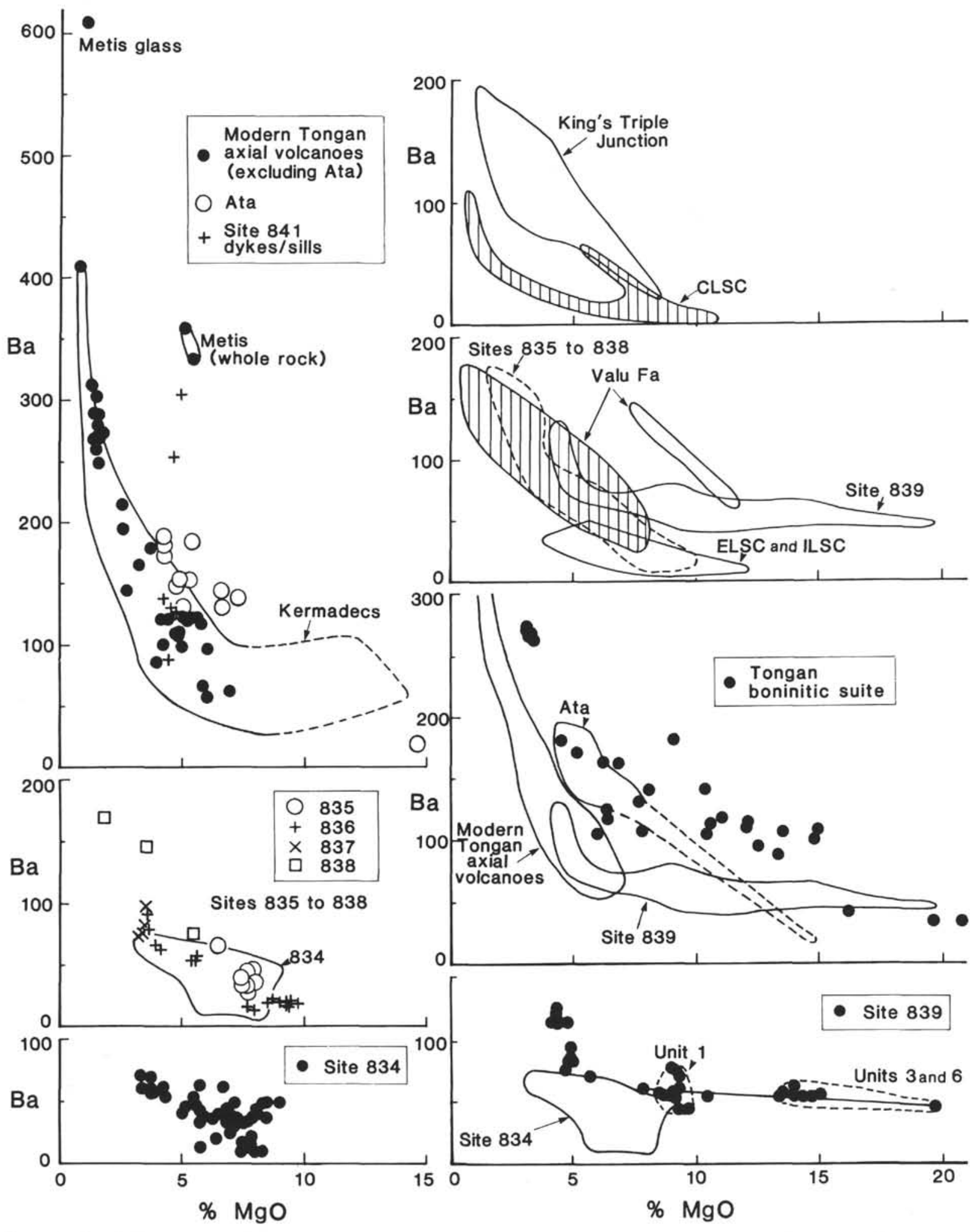

Figure 12. Compilation of Ba-MgO data for the modern Lau Basin spreading centers, Sites 834-839, the Tonga-Kermadec modern axial volcanoes, and the northern Tonga boninites. The tie-line joins a coexisting whole rock-matrix pair. 
Table 7. Selected element ratios within the various Leg 135 sites, compared with other volcanic provinces within the Lau-Tonga-Kermadec region.

\begin{tabular}{|c|c|c|c|c|c|c|c|c|c|c|c|c|c|}
\hline & $\mathrm{Rb} / \mathrm{Cs}$ & $\mathrm{K} / \mathrm{Nb}$ & $\mathrm{Ba} / \mathrm{La}$ & $\mathrm{La} / \mathrm{Nb}$ & $\mathrm{Zr} / \mathrm{Ba}$ & $\mathrm{Zr} / \mathrm{Sm}$ & $\mathrm{Sr} / \mathrm{Nd}$ & $\mathrm{Sm} / \mathrm{Hf}$ & $\mathrm{Ce} / \mathrm{Sm}$ & $\mathrm{Ce} / \mathrm{Pb}$ & $\mathrm{Nb} / \mathrm{Th}$ & $\mathrm{Nb} / \mathrm{Nb}$ (MORB) & $\mathrm{Zr} / \mathrm{Zr}(\mathrm{MORB})$ \\
\hline \multicolumn{14}{|l|}{ Leg 135: } \\
\hline Site $834(>5 \% \mathrm{MgO})$ & $5.29-45.0$ & $603-2214$ & $2.06-10.1$ & $1.23-3.13$ & $1.59-15.0$ & $26.4-35.5$ & $12.4-20.1$ & $1.01-1.54$ & $2.76-3.62$ & $6.90-14.1$ & $3.25-22.9$ & $0.39-1.06$ & $1.05-2.01$ \\
\hline Site 835 & $23.6-26.7$ & $3219-3672$ & $11.1-13.8$ & $3.85-4.82$ & $0.77-1.67$ & $17.4-22.5$ & $18.9-25.0$ & $1.76-2.02$ & $2.43-2.61$ & $7.15-7.88$ & $2.72-4.73$ & $0.21-0.22$ & $0.59-0.66$ \\
\hline Site $836(>5 \% \mathrm{MgO})$ & $92-180(31.3)$ & $1012-2584$ & $7.91-23.8$ & $1.56-2.46$ & $0.88-5.37$ & $29.8-47.3$ & $28.8-50.7$ & $0.76-1.24$ & $2.42-3.08$ & $2.33-3.29$ & $82-106$ & $0.18-0.45$ & $0.49-0.81$ \\
\hline Site 837 & $88.8-126$ & $2151-2978$ & $16.7-16.8$ & $2.54-2.60$ & $0.78-0.93$ & $17.7-17.8$ & $12.5-12.8$ & $1.60-1.61$ & $3.11-3.12$ & $8.84-9.17$ & $4.49-5.36$ & $0.79-0.83$ & $1.0-1.03$ \\
\hline Site 839 & $25.6-74.0$ & $5747-13559$ & $19.7-38.0$ & $4.20-8.13$ & $0.38-0.80$ & $13.2-21.6$ & $25.7-38.1$ & $1.73-2.15$ & $2.29-3.65$ & $2.77-9.47$ & $1.44-3.30$ & $0.077-0.33$ & $0.35-0.73$ \\
\hline \multicolumn{14}{|l|}{ Lau Basin spreading centers: } \\
\hline $\mathrm{KTJ}(>7 \% \mathrm{MgO})$ & - & 229-1845 & $3.57-11.8$ & $1.25-1.98$ & $1.37-3.17$ & $19.1-31.3$ & $14.8-15.5$ & $1.35-1.99$ & $3.29-3.73$ & - & 9.6 & $0.38-1.24$ & $0.72-1.07$ \\
\hline $\mathrm{CLSC}(>7 \% \mathrm{MgO})$ & $39.7-77.0$ & $208-2352$ & $3.98-13.9$ & $0.65-6.78$ & $1.45-7.51$ & $15.7-27.0$ & $10.3-36.7$ & $1.40-2.05$ & $1.52-3.57$ & $4.12-36.6$ & $6.77-32.9$ & $0.26-3.00$ & $0.47-1.01$ \\
\hline $\mathrm{ELSC}$ and $\mathrm{ILSC}(>7 \% \mathrm{MgO})$ & - & $218-1449$ & $4.43-13.5$ & $0.98-2.84$ & $1.49-7.85$ & $18.3-25.9$ & $10.5-37.4$ & $1.26-1.78$ & $2.14-3.28$ & $3.46-11.5$ & $3.0-16.2$ & $0.26-0.92$ & $0.46-0.85$ \\
\hline Valu $\mathrm{Fa}(>7 \% \mathrm{MgO})$ & $37.1-48.6$ & $6641-19647$ & $32.5-48.8$ & $3.35-14.7$ & $0.26-1.19$ & $18.1-22.7$ & $32.4-37.8$ & $1.94-2.00$ & $2.21-4.02$ & - & $0.58-2.38$ & $0.13-0.17$ & $0.32-0.50$ \\
\hline $\begin{array}{l}\text { Niua fo'ou: } \\
\text { (Oceanic }\end{array}$ & & & & & & & & & & & & & \\
\hline (Oceanic Island Volcano) & $67.5-85.0$ & $381-442$ & $8.0-10.5$ & $1.14-1.27$ & $2.45-3.23$ & $26.0-34.5$ & $12.5-18.3$ & $1.07-1.65$ & $3.36-4.48$ & $9.46-12.2$ & $12.2-17.6$ & $1.59-1.94$ & $1.26-1.62$ \\
\hline \multicolumn{14}{|l|}{ Lau Ridge: } \\
\hline $\mathrm{LVG}(>4 \% \mathrm{MgO})$ & - & 1992 & $19.8-26.2$ & 2 & $0.46-0.91$ & $15.0-18.7$ & $22.9-33.1$ & $2.05-2.27$ & $4.1-4.46$ & - & 4.29 & 1.29 & $1.16-0.89$ \\
\hline $\mathrm{KVG}(>4 \% \mathrm{MgO})$ & - & 5811 & 32.9 & 4 & $0.14-0.15$ & $8.84-8.97$ & $42.8-51.8$ & $2.44-3.55$ & $2.51-3.59$ & - & 4.54 & 0.86 & $0.35-0.51$ \\
\hline \multicolumn{14}{|l|}{ Tonga Ridge: } \\
\hline North Tonga-Station 21 & - & $1785-5313$ & $28.6-59.9$ & $1.56-3.94$ & $0.087-0.18$ & $9.86-17.0$ & $35.2-78.8$ & $1.04-2.56$ & $4.42-9.10$ & - & $1.22-3.23$ & $(0.43-0.86)^{\circ}$ & $0.12-0.31$ \\
\hline Tafahi Island & 20.9 & 2649 & $45.6-160$ & 2.23 & $0.12-0.29$ & $15.7-18.4$ & $73.2-116$ & 2.21 & $3.0-3.72$ & $1.0-1.9$ & 3.13 & 0.20 & $0.19-0.20$ \\
\hline Fonualei Island & $41.5-61.1$ & $4300-8528$ & $35.5-90.0$ & $2.37-3.27$ & $0.15-0.21$ & $17.7-21.3$ & $29.5-48.5$ & $1.77-1.92$ & $3.66-4.11$ & $2.30-2.90$ & $1.43-4.34$ & $0.47-0.60$ & $0.50-0.69$ \\
\hline Late Island & $10.0-53.8$ & 7621 & $35.6-89.3$ & $3.0-3.87$ & $0.19-0.28$ & $15.8-21.5$ & $43.0-95.8$ & $1.65-1.72$ & $3.23-3.62$ & $1.77-2.69$ & 2.65 & 0.26 & $0.31-0.39$ \\
\hline Metis Shoal & 17.7 & 15897 & $116-124$ & 6.66 & 0.13 & 24.5 & $24.8-26.1$ & 1.36 & $3.85-4.69$ & 1.63 & 1.57 & 0.21 & 0.62 \\
\hline Kao Island & 42.5 & $2283-5798$ & 44.3 & 7.75 & $0.38-0.42$ & 18.9 & 27.4 & 1.65 & 3.11 & 5.3 & 1.74 & $0.17-0.52$ & $0.63-0.69$ \\
\hline Tofua Island & 44.7 & 14162 & $74.9-76.4$ & 6.68 & $0.19-0.25$ & $17.6-20.4$ & $29.5-36.9$ & 1.67 & 2.84 & 2.25 & 1.70 & 0.15 & $0.58-0.72$ \\
\hline Hunga Ha'apai & 30.8 & 3832 & $78.3-98.4$ & 3.46 & $0.17-0.24$ & $15.4-27.5$ & $42.6-57.0$ & 1.71 & $2.94-3.29$ & $2.27-4.21$ & 3.71 & 0.22 & $0.32-0.41$ \\
\hline 'Ata & $28.5-95.9$ & - & $37.5-47.7$ & - & $0.23-0.32$ & $18.7-24.5$ & $33.5-45.7$ & $1.65-2.39$ & $3.63-4.92$ & $0.74-1.29$ & - & - & $0.54-0.76$ \\
\hline \multicolumn{14}{|l|}{ Kermadec Ridge: } \\
\hline Raoul Group & $20.9-40.9$ & $2398-5811$ & $35.6-68.3$ & $1.62-5.89$ & $0.26-0.83$ & $14.8-23.1$ & $21.7-58.1$ & $1.53-2.25$ & $2.63-3.61$ & $3.3-4.08$ & $1.29-2.14$ & $0.17-0.49$ & $0.22-0.93$ \\
\hline Macauley Island & 33.1 & $5283-5444$ & $41.3-72.2$ & $5.59-6.39$ & $0.23-0.44$ & $13.0-16.9$ & $31.5-93.8$ & $1.97-2.02$ & $2.85-4.95$ & $1.82-5.72$ & $1.30-1.69$ & $0.094-0.26$ & $0.16-0.54$ \\
\hline L'Esperance & $24.8-39.4$ & $3605-6074$ & $34.8-70.5$ & $4.21-7.61$ & $0.23-0.32$ & $15.3-19.5$ & $28.1-39.8$ & $1.80-1.94$ & $3.41-4.48$ & $3.11-5.53$ & $0.80-1.73$ & $0.18-0.33$ & $0.50-0.61$ \\
\hline
\end{tabular}

Notes: Data based on Tables 2-5 and published data (see text). Nb/Nb(MORB) and Zr/Zr(MORB) are N-MORB normalized, based on values from Sun and McDonough (1989). Value marked by an asterisk (*) was determined by X-ray fluorescence (XRF). KTJ $=$ King's Triple Junction, CLSC $=$ Central Lau Spreading Center, ELSC $=$ Eastern Lau Spreading Center, ILSC $=$ Intermediate Lau Spreading Center, LVG $=$ Lau Volcanic Group, and KVG $=$ Korobasaga
Volcanic Group. Tafahi, Late, Kao, Tofua, Hunga Ha'apai, and L'Esperance islands composed of basaltic andesites; North Tonga-Station 21 composed of boninitic lavas; Fonualei Island composed of andesites and dacites; Metis Shoal Volcanic Group. Tafahi, Late, Kao, Tofua, Hunga Ha'apai, and L'Esperance islands composed of basaltic andesites; North Tonga-Station 2
composed of dacite/rhyolite; 'Ata and Raoul Group composed of basalts and basaltic andesites; and Macauley Island composed of basalts. 


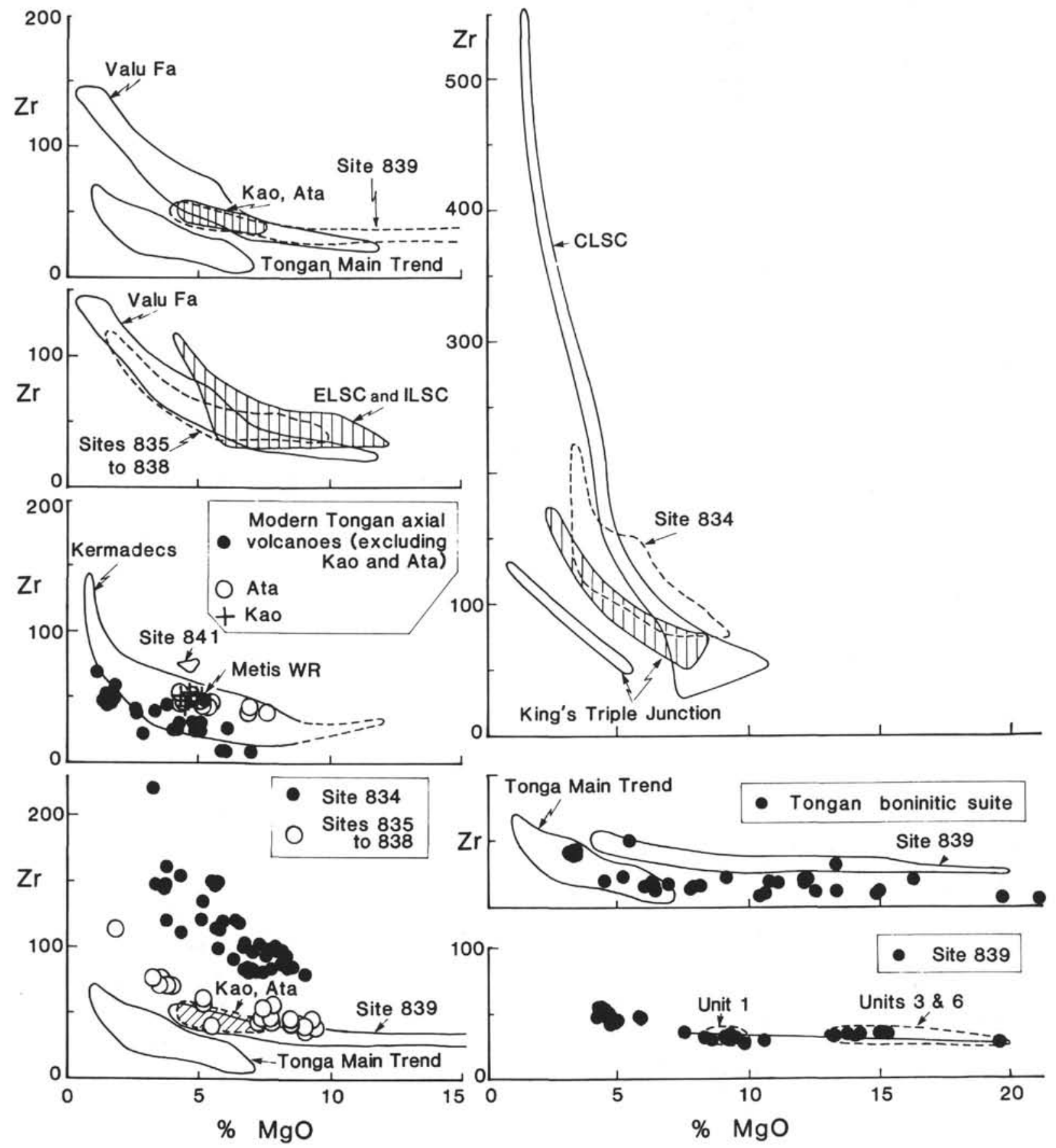

Figure 13. Compilation of $\mathrm{Zr}-\mathrm{MgO}$ data, as in Figure 12. 
A. EWART, W.B. BRYAN, B.W. CHAPPELL, R.L. RUDNICK
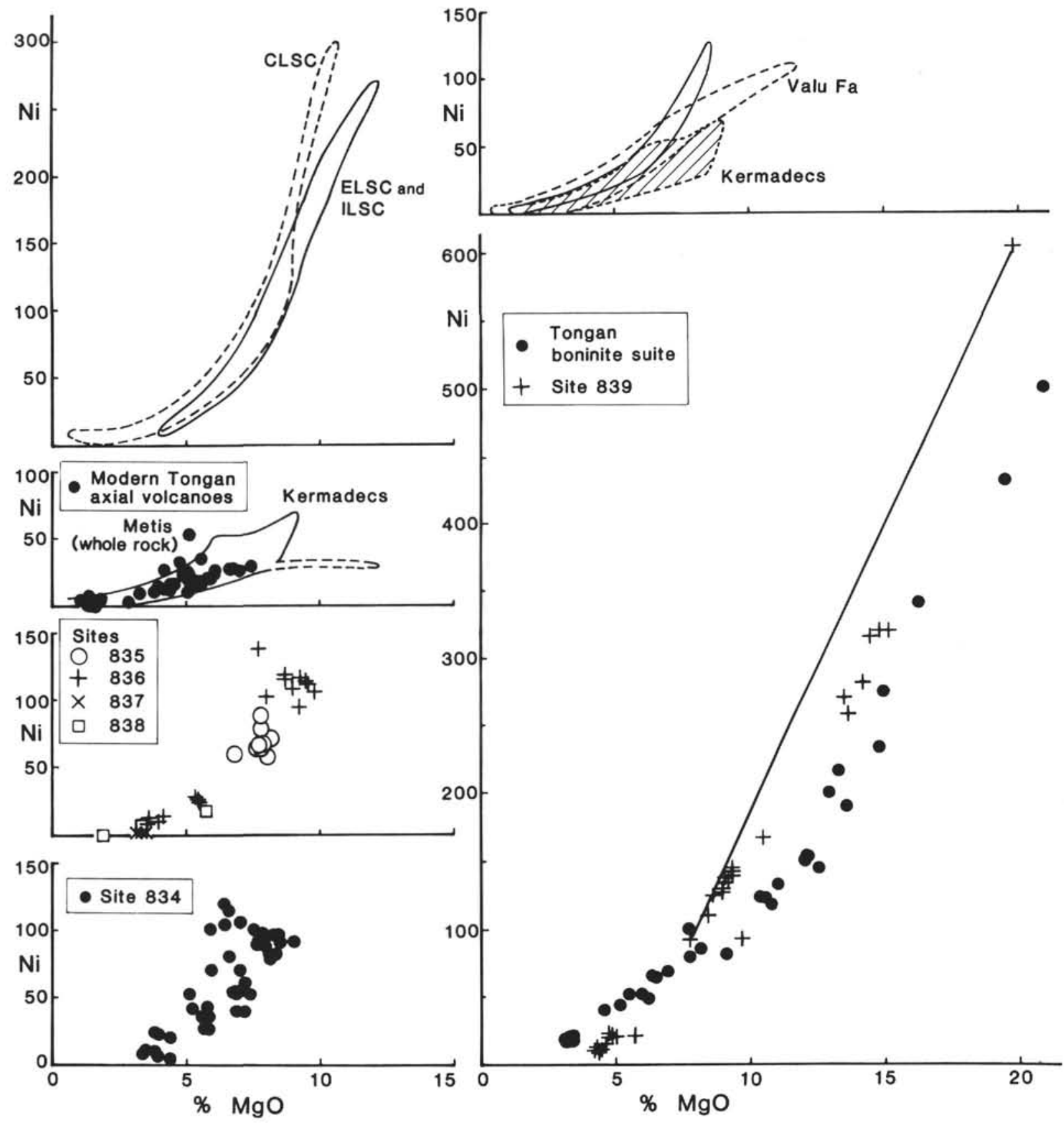

Figure 14. Compilation of $\mathrm{Ni}-\mathrm{MgO}$ data, as in Figure 12. 


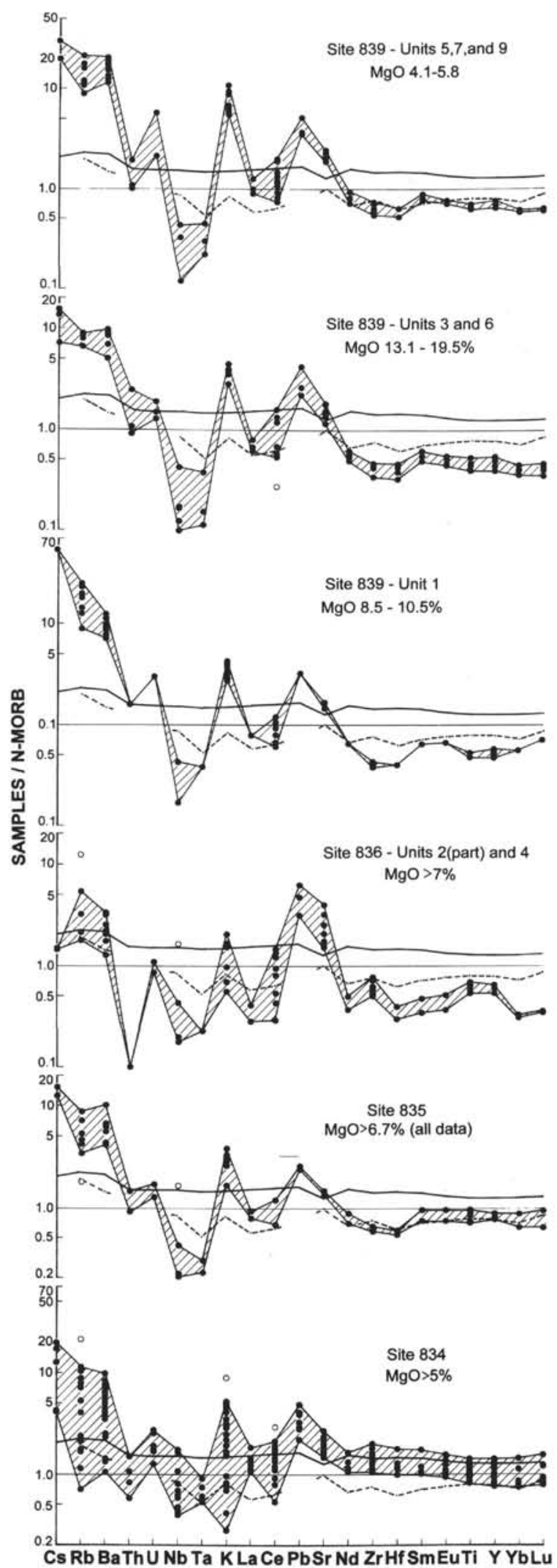

Figure 15. Element abundances of lavas from Sites 834-839 normalized to N-MORB values of Sun and McDonough (1989). Data from shipboard analyses (Parson, Hawkins, Allan, et al., 1992) and Tables 2-5. Only the more magnesian lavas are included. The open circles represent what are inferred to be outlying values. The heavy continuous line represent the N-MORB values of Hofmann (1988), whereas the heavy dashed lines are the minimum N1MORB values of Viereck et al. (1989). 


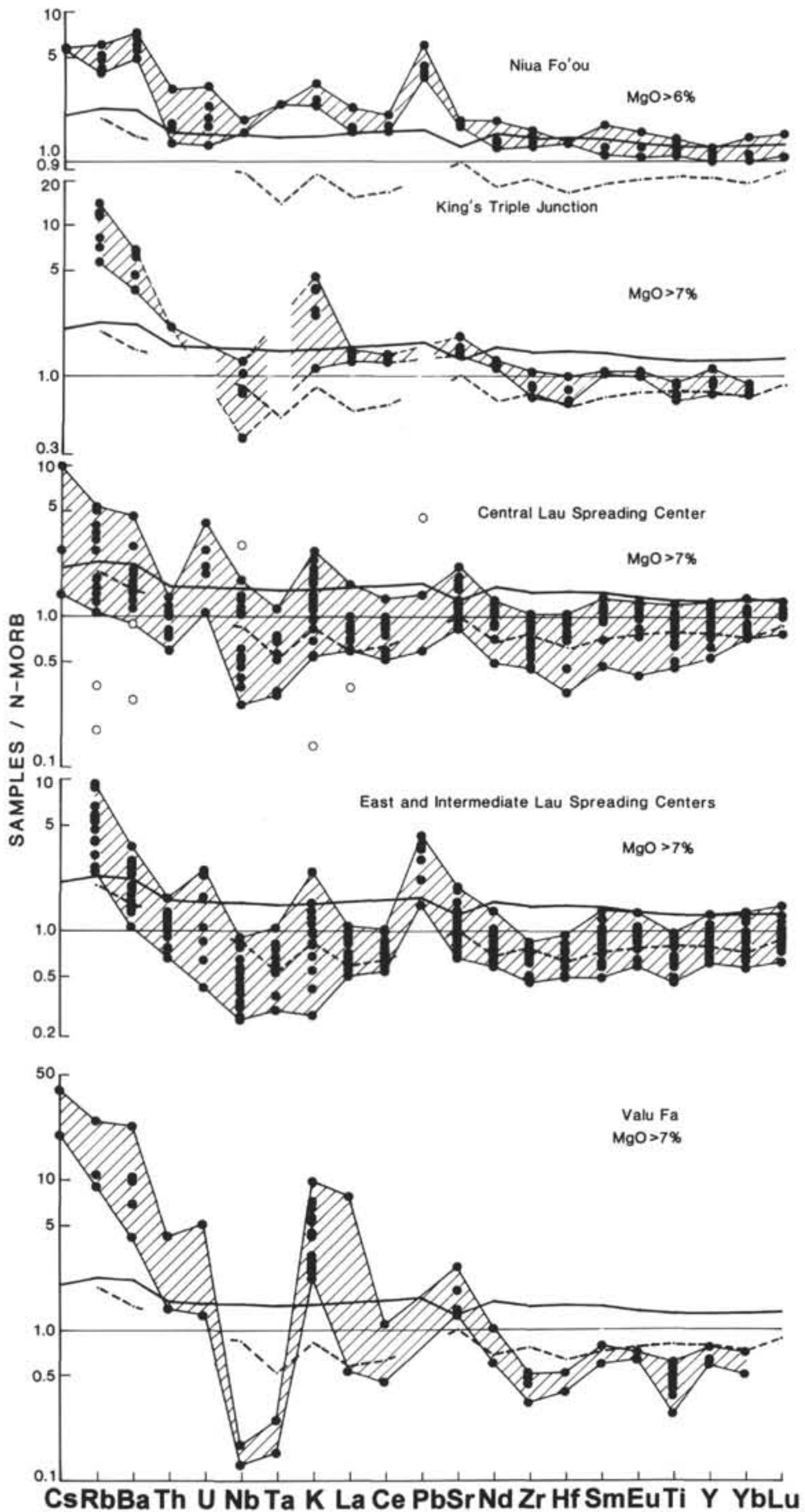

Figure 16. Element abundances of lavas from the Lau Basin spreading centers, and the island of Niuafo'ou, normalized to N-MORB values. Only the most magnesian lavas are plotted. Data sources listed in text. N-MORB values and curves as in Figure 15. 

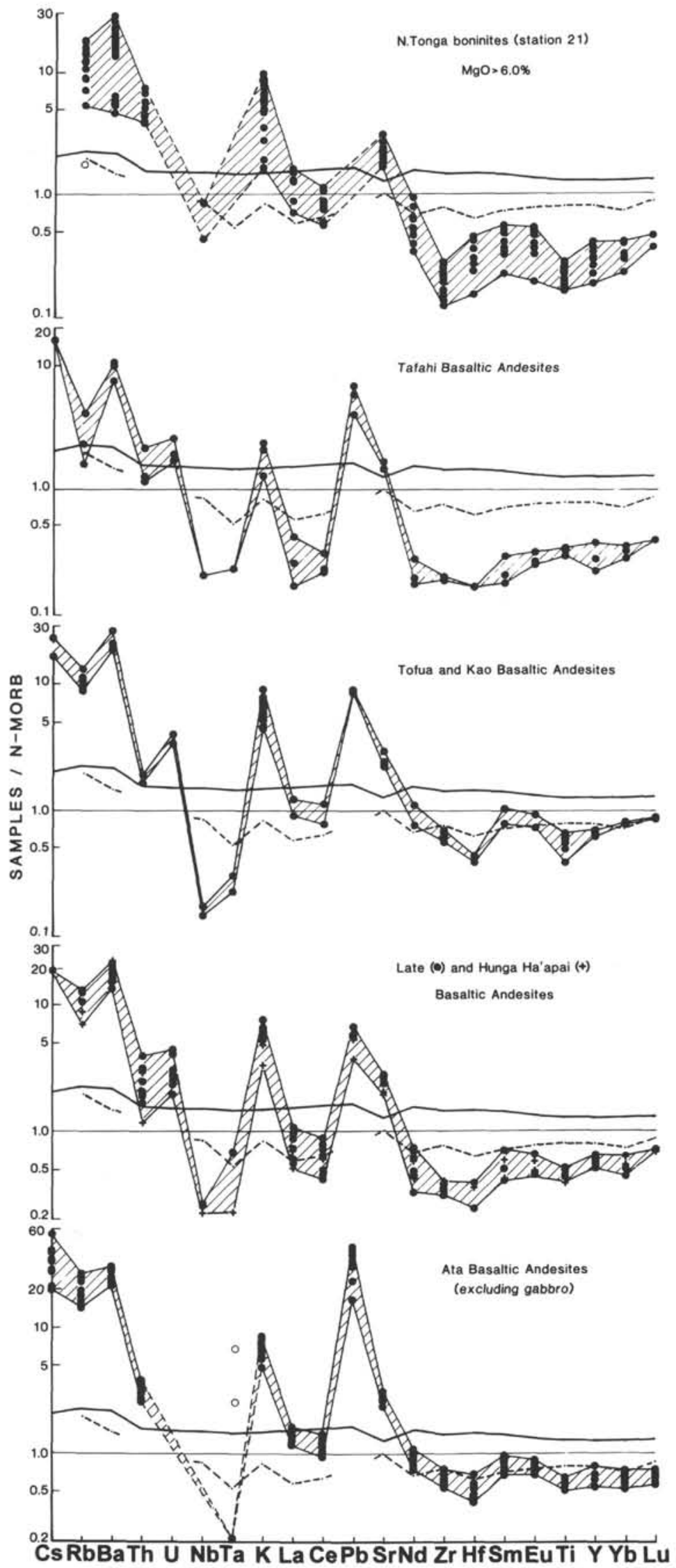

Figure 17. Element abundances of the modern Tofua Arc volcanoes (basaltic andesites only), and the northern Tonga boninites, from Station 21, normalized to N-MORB values. Normalizing factors and curves as in Figure 15. 


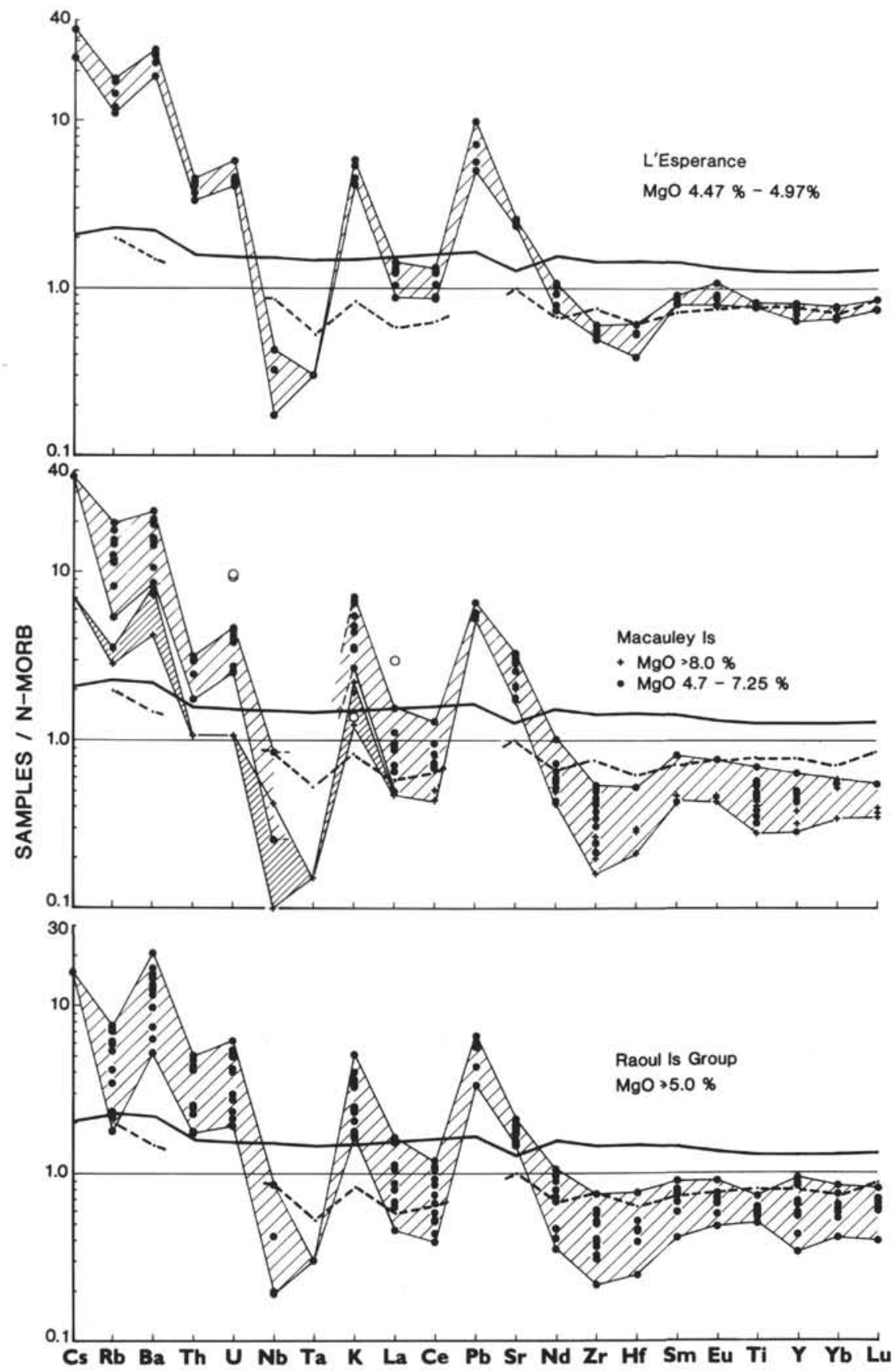

Figure 18. Element abundances of the modern Kermadec volcanoes (basalts and basaltic andesites only), normalized to N-MORB. Normalizing factors as in Figure 15. 


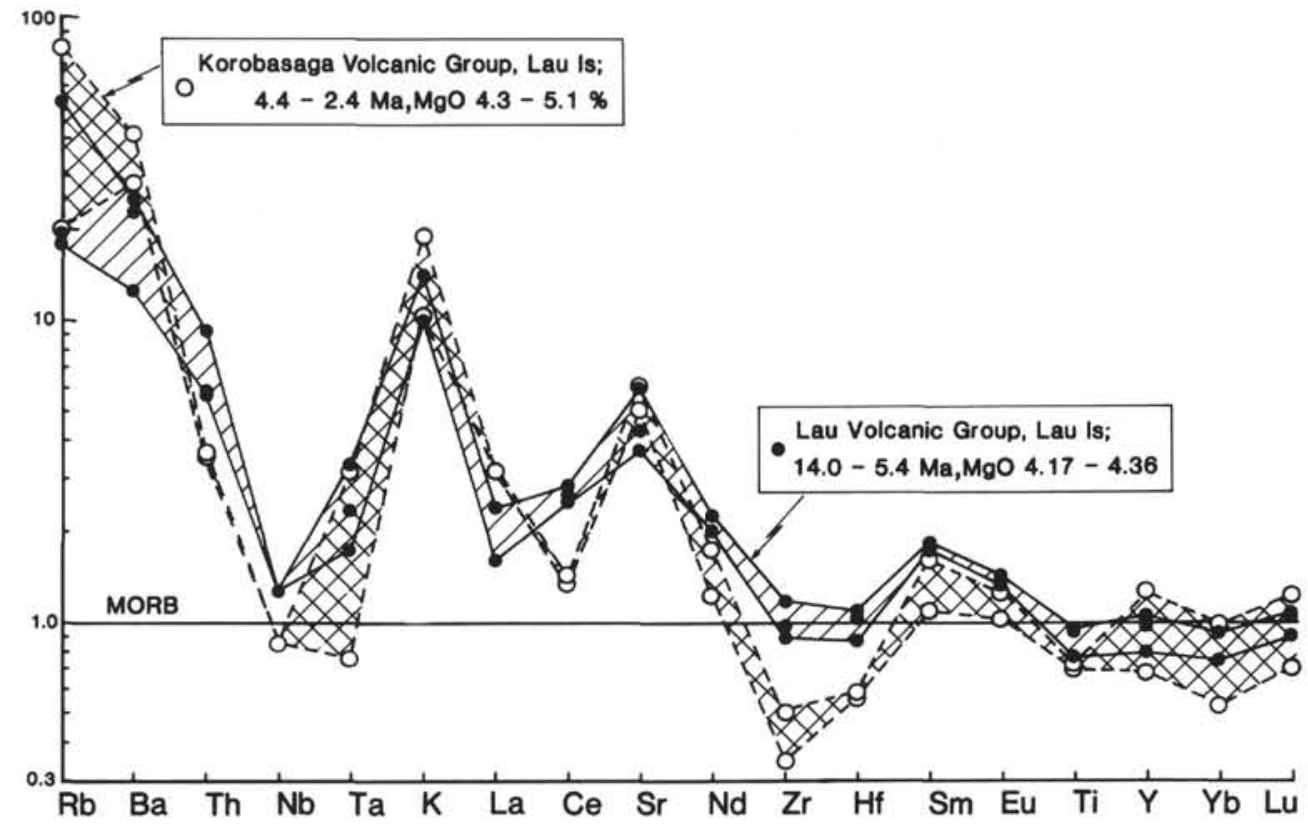

Figure 19. Element abundances of the Lau and Korobasaga Volcanic Groups, Lau Islands (after Cole et al., 1990), normalized to N-MORB. 

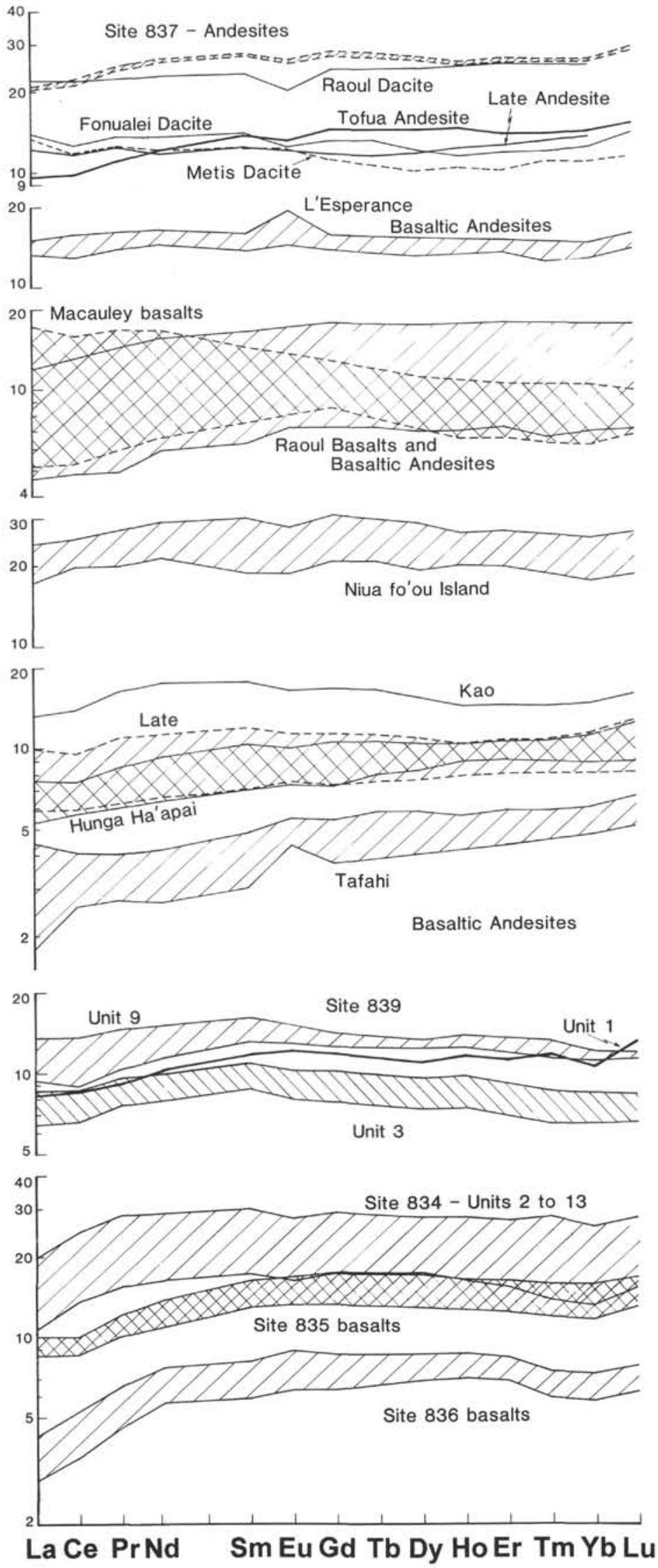

Figure 20. Chondrite normalized REE (Sun and McDonough, 1989) patterns for Sites 834-839 lavas (Tables 2-5), the modern Tofua Arc volcanoes, Niuafo'ou, and the modern Kermadec Arc volcanoes. 


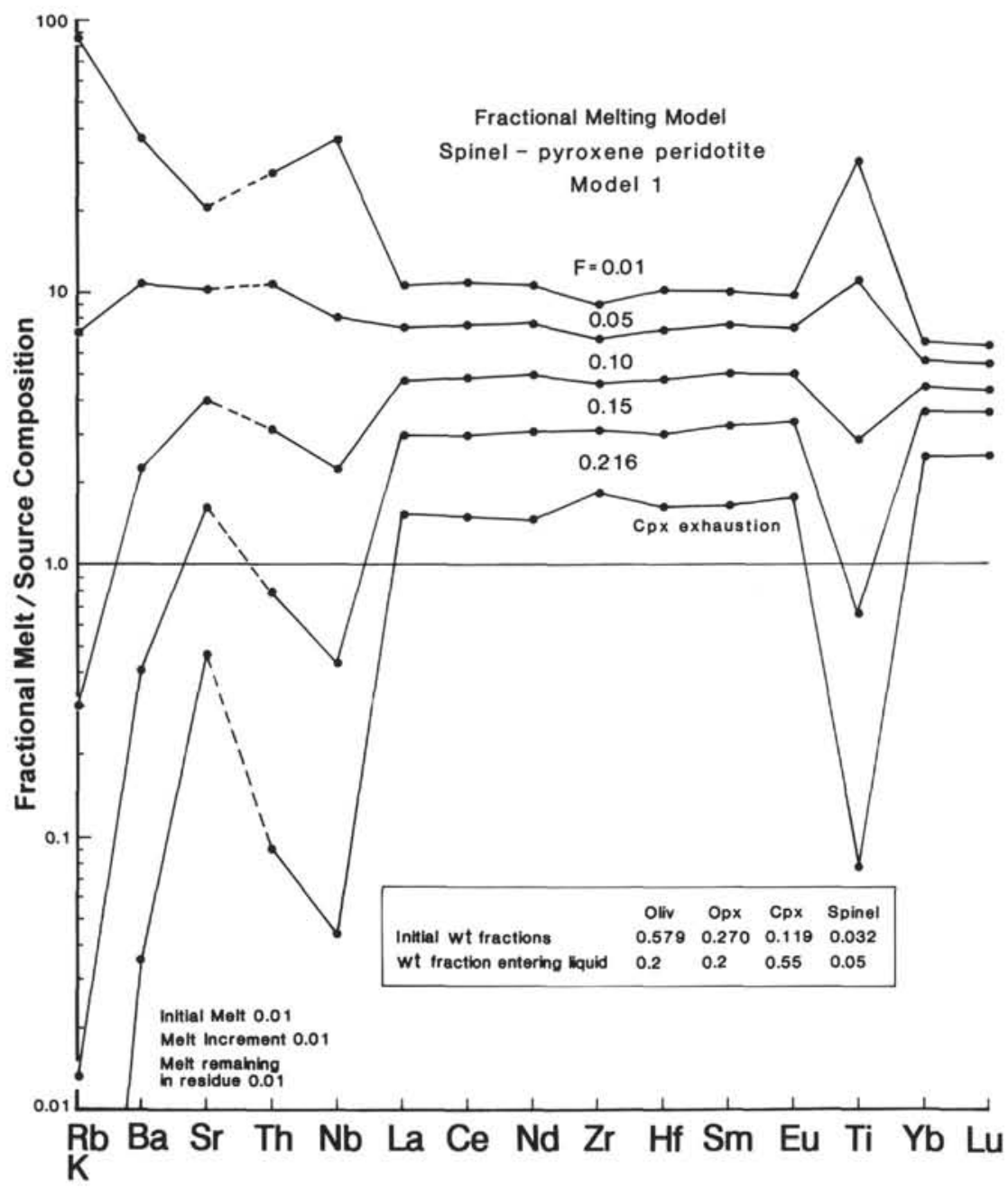

Figure 21. Results of four sets of calculations showing the progressive change of selected trace and minor element compositions in melts from two model peridotite sources undergoing fractional melting. Melt compositions normalized to starting source composition, and based on increments of melt fractions (= F) as shown. Models 1 and 3 based on spinel-pyroxene peridotite. Models 2 and 4 based on amphibole peridotite. Models 1 and 3 and Models 2 and 4 differ with respect to the partition coefficients used (listed in Table 6). Initial melt, melt increments, and melt remaining in residue are all taken as 0.01 (= melt fractions). 

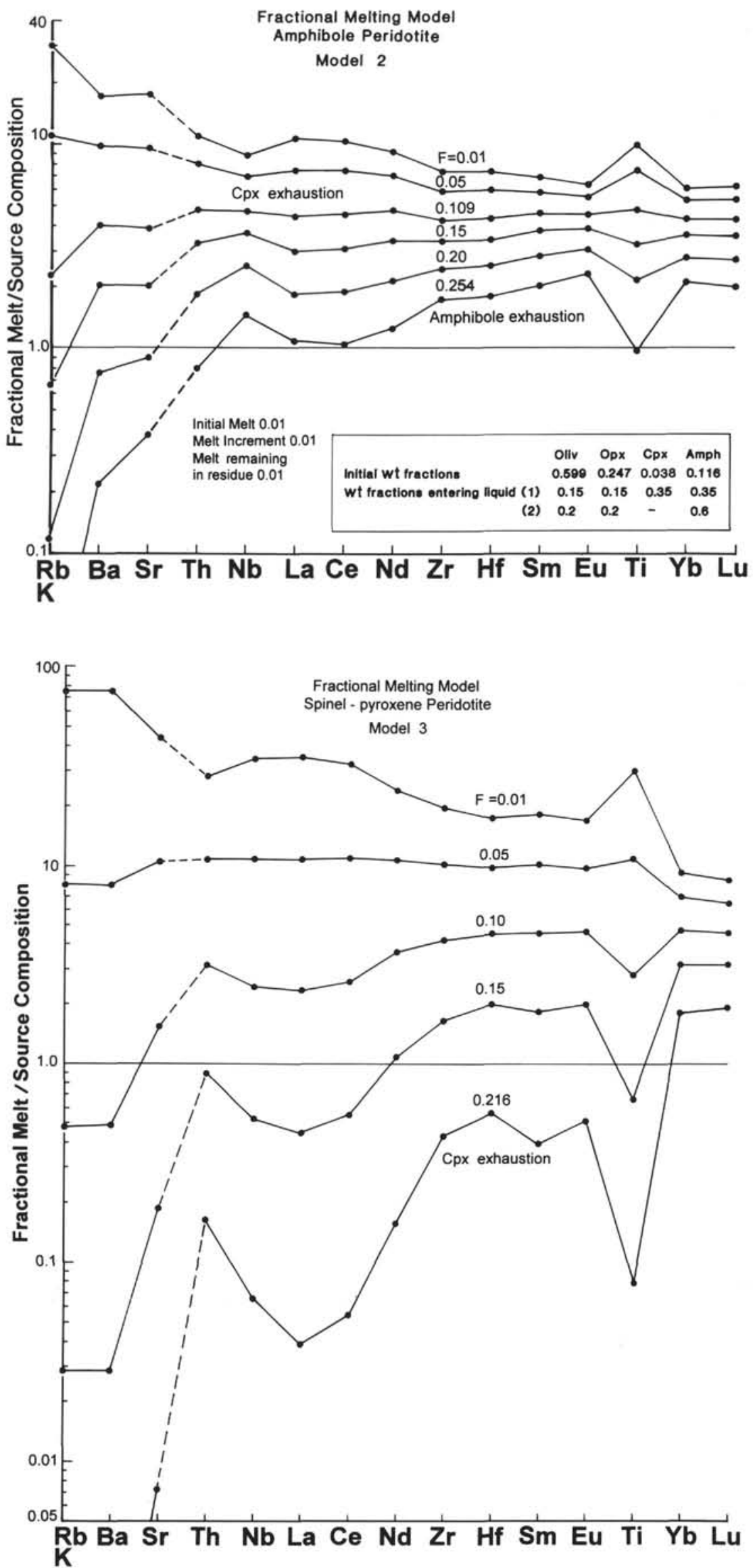

Figure 21 (continued). 


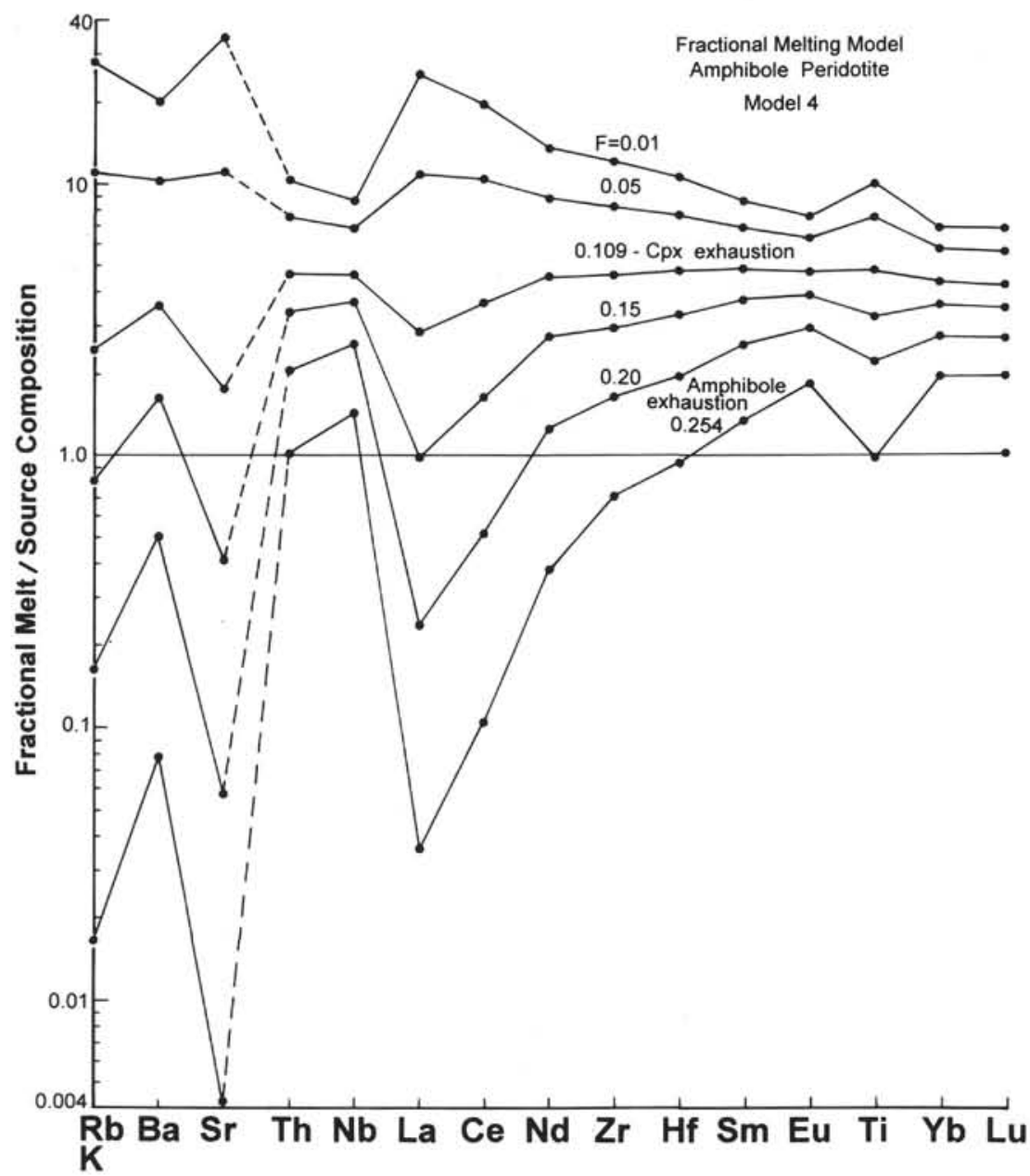

Figure 21 (continued). 


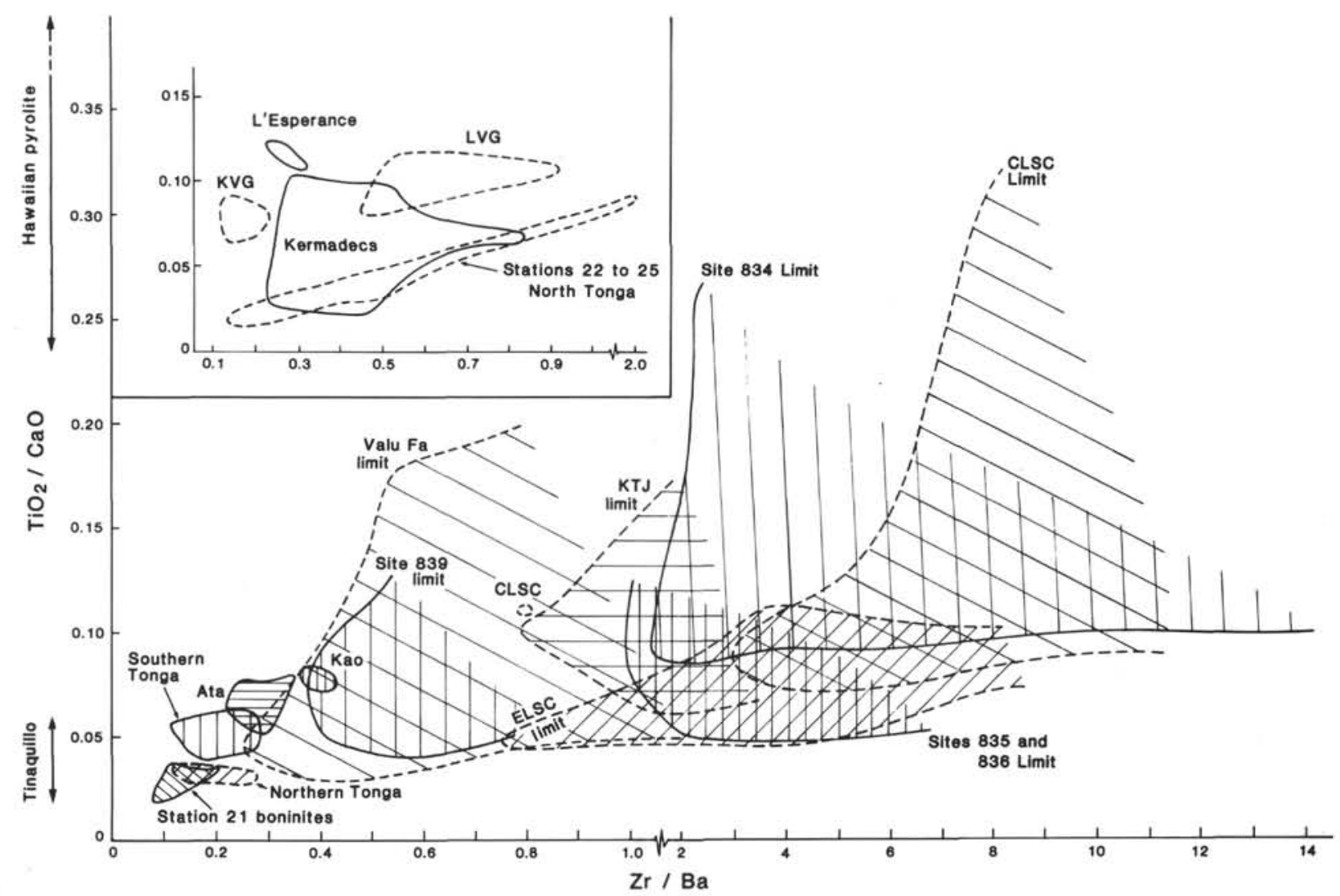

Figure 22. Comparison of the compositional fields, in terms of $\mathrm{TiO}_{2} / \mathrm{CaO}$ vs. $\mathrm{Zr} / \mathrm{Ba}$ ratios, of Sites $834-836$ and 839 lavas with the Lau Basin spreading centers, the modern Tonga-Kermadec volcanoes, and the northern Tonga boninites.

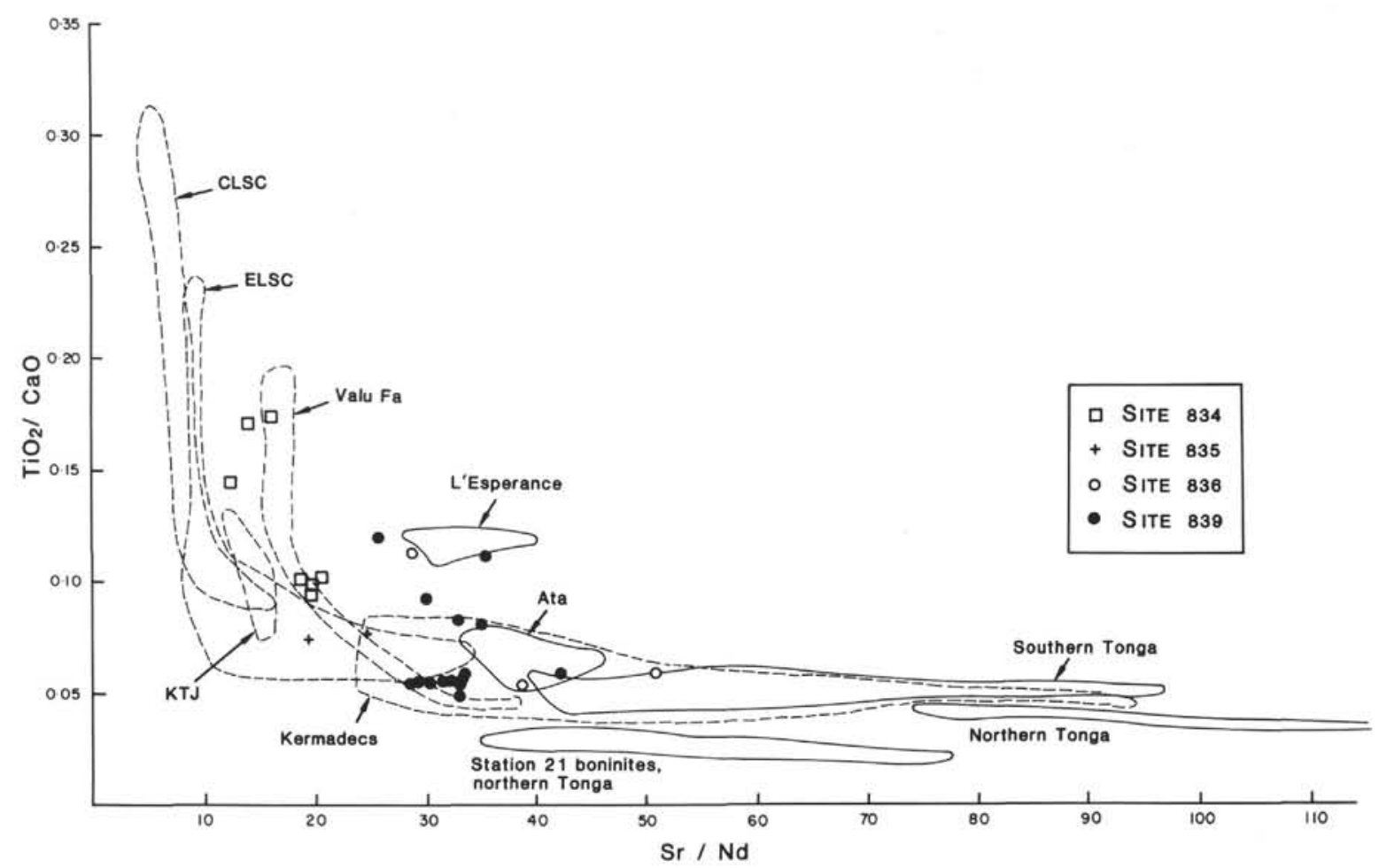

Figure 23. Compositional fields, in terms of $\mathrm{TiO}_{2} / \mathrm{CaO}$ and $\mathrm{Sr} / \mathrm{Nd}$ ratios, of Sites $834-836$ and 839 lavas with those of the Lau Basin spreading centers, the modern Tonga-Kermadec arc volcanoes, and the northern Tonga boninites. 


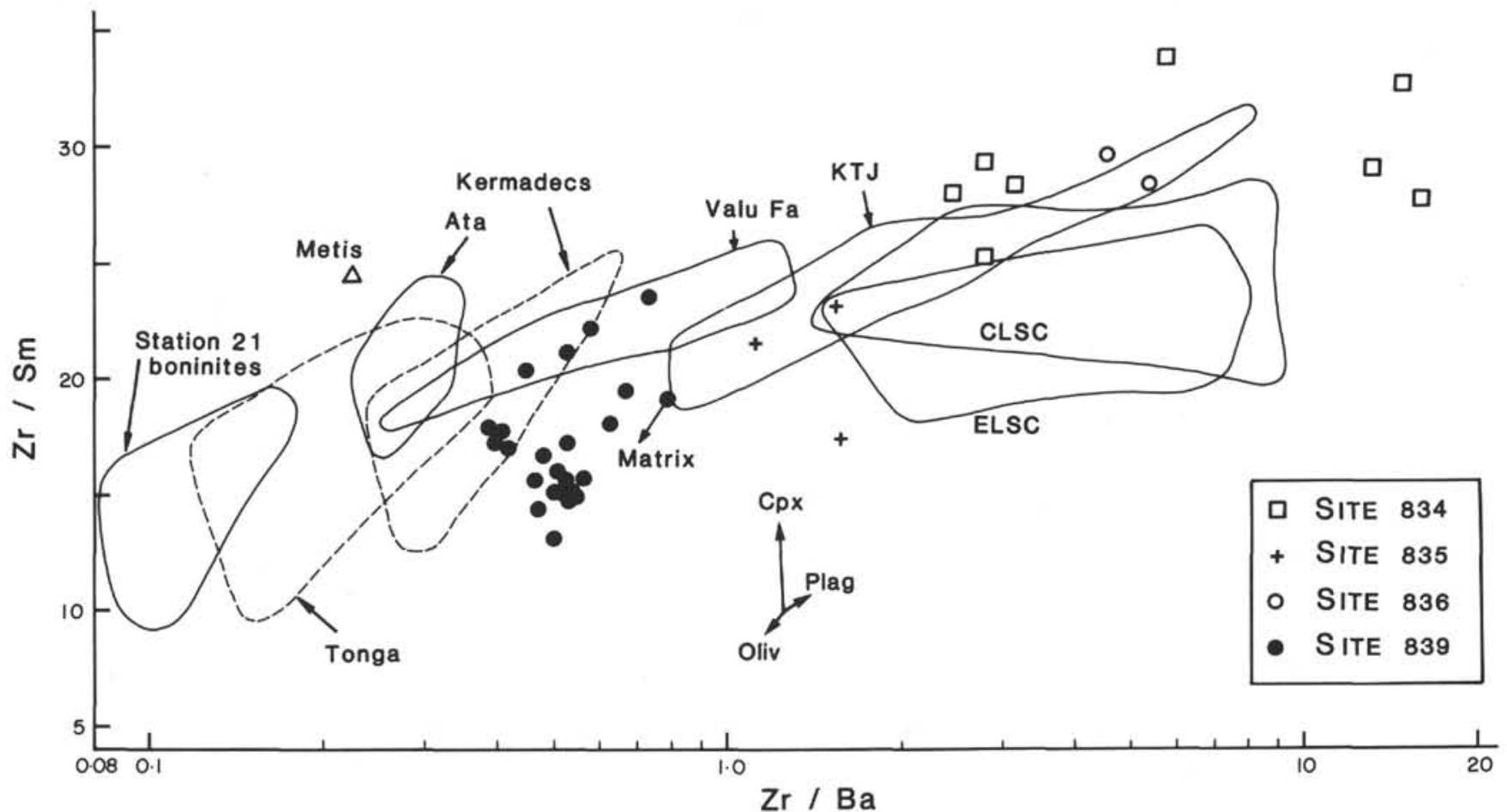

Figure 24. $\mathrm{Zr} / \mathrm{Sm}$ vs. $\mathrm{Zr} / \mathrm{Ba}$ ratios for the Lau-Tonga-Kermadec lavas. The effects of fractionation of clinopyroxene, olivine, and plagioclase (to $\mathrm{F}=0.5$ ) are shown by the vectors. 


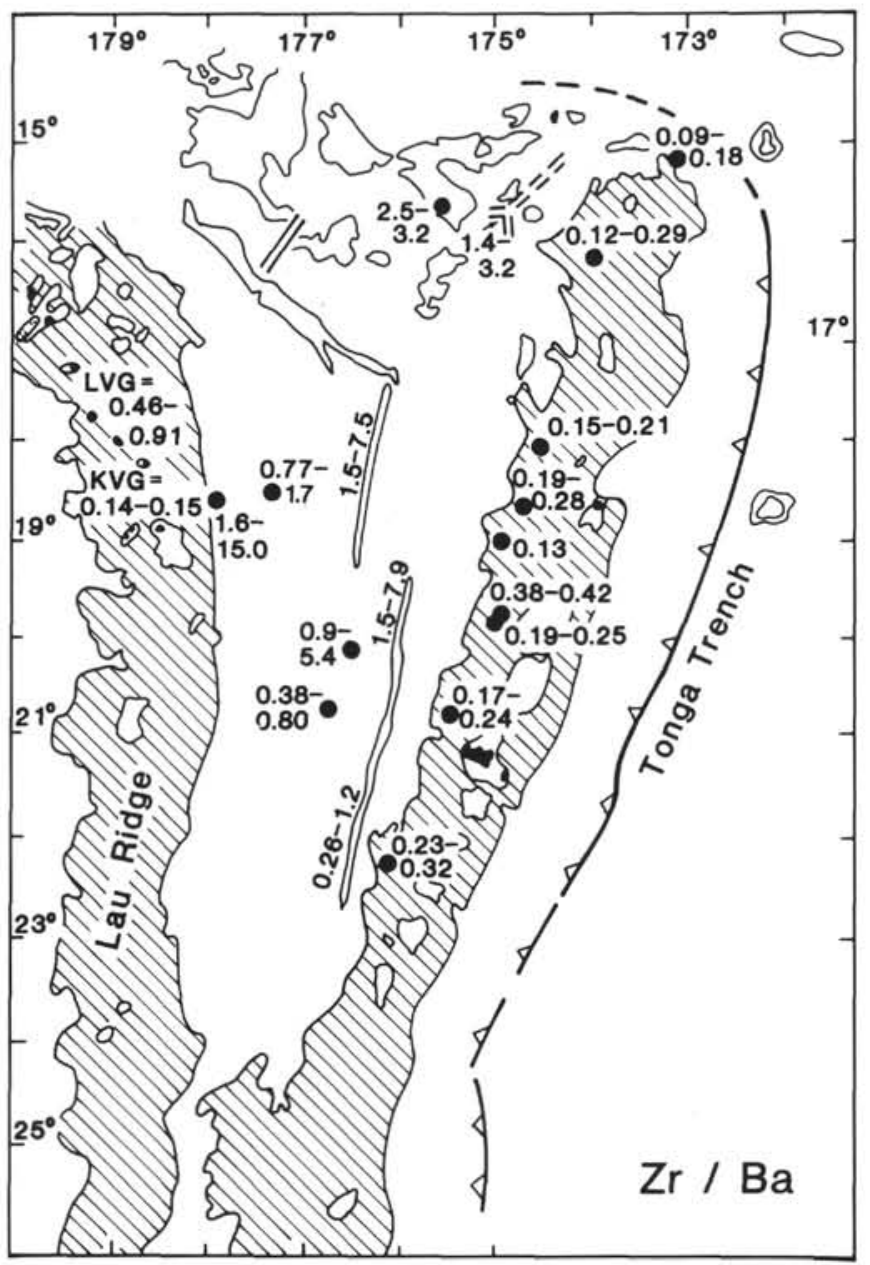

Figure 25. Simplified map of the Lau-Tonga region showing the regional variations and ranges of $\mathrm{Zr} / \mathrm{Ba}$ ratios within the lavas, including those recovered during Leg 135. Based on data presented in Table 7. 
$\sim 14-10 \mathrm{Me}$

Former Lau - Tonga single ridge

Lau Volcanic Group

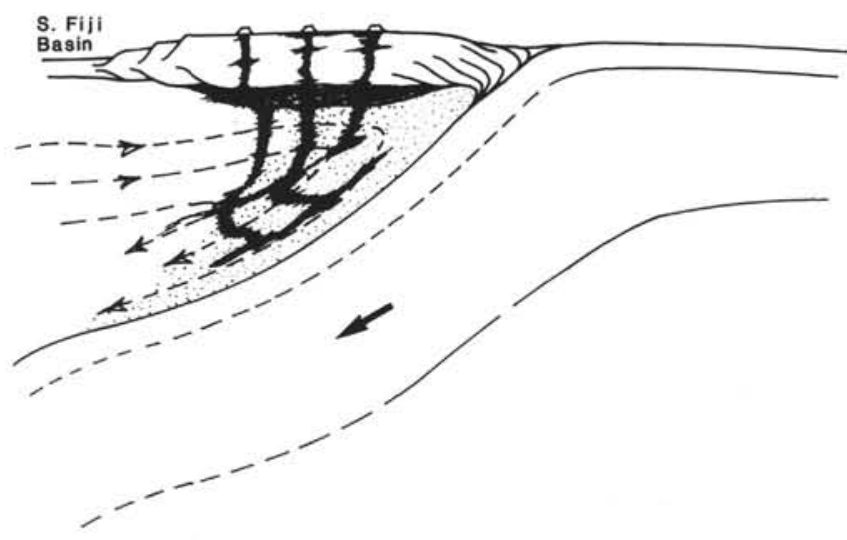

? Proto Tofua arc (Site 839)

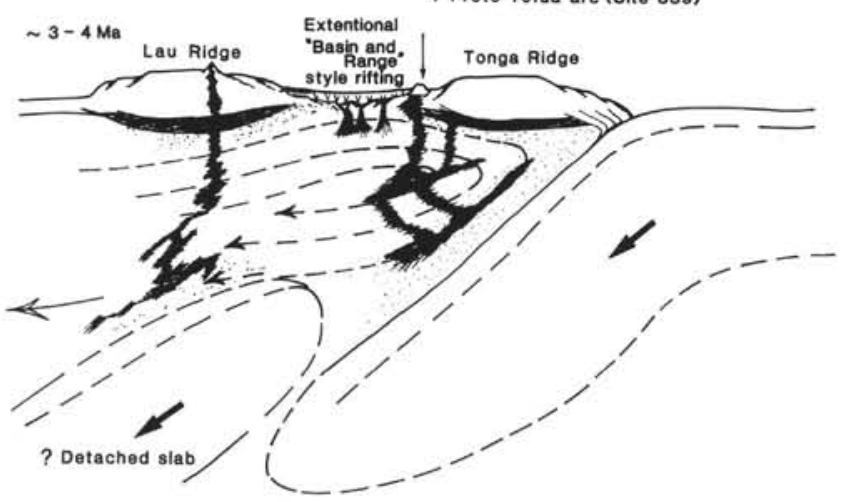

$---\rightarrow$
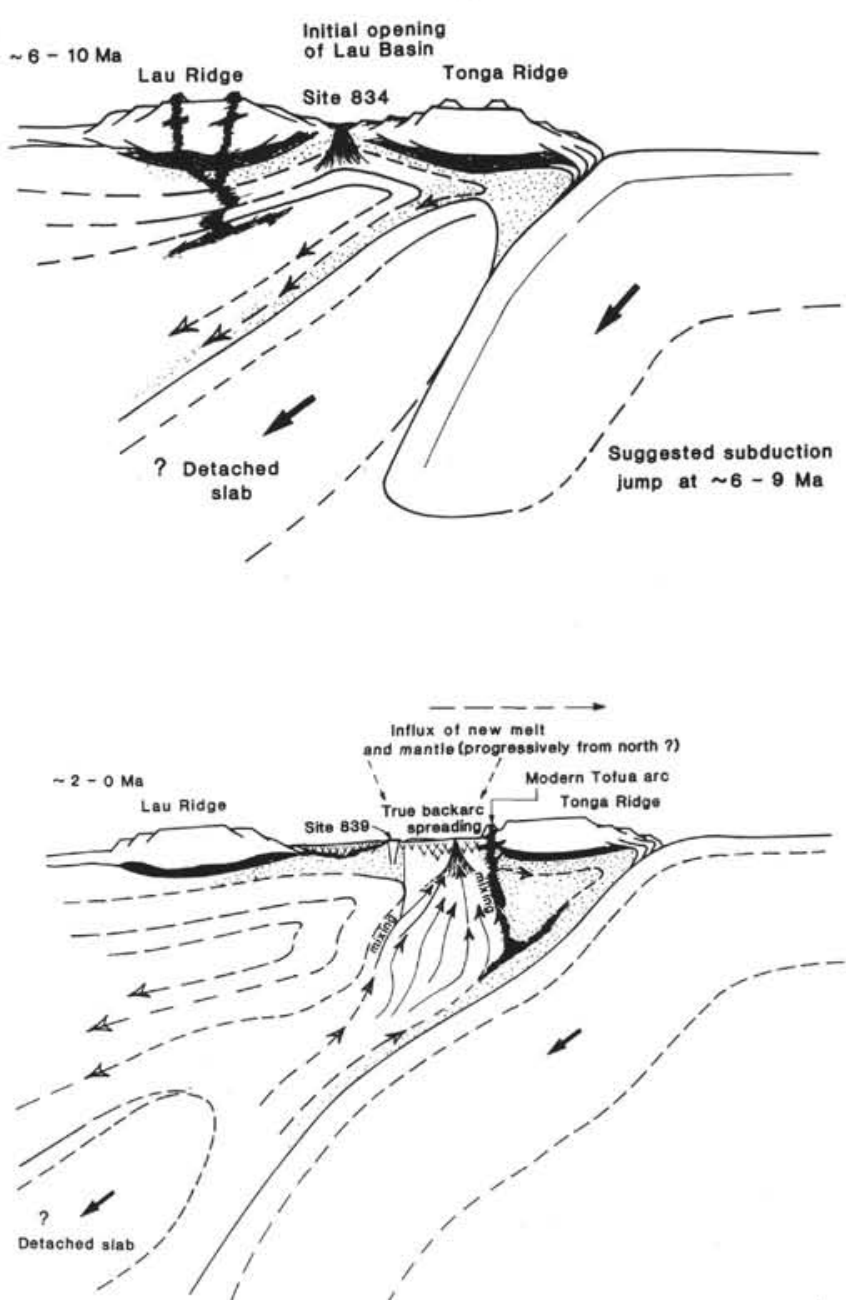

Figure 26. A sequence of four highly speculative east-west sections, in the region of about latitudes $18^{\circ}-20^{\circ} \mathrm{S}$, suggesting mechanisms by which the Lau-Tonga systems may have evolved. The stippling shows the inferred extent of the subduction-derived component into the mantle wedge. 